\author{
A Thesis \\ Submitted to the Faculty of Graduate Studies and Research \\ In Partial Fulfillment of the Requirements \\ For the Degree of
}

Master of Science

in

Kinesiology and Health Studies

University of Regina

By

Patrick Bernat

Regina, Saskatchewan

February 2019

Copyright (C) 2019: P. Bernat 


\section{UNIVERSITY OF REGINA}

\section{FACULTY OF GRADUATE STUDIES AND RESEARCH SUPERVISORY AND EXAMINING COMMITTEE}

Patrick Bernat, candidate for the degree of Master of Science in Kinesiology \& Health Studies, has presented a thesis titled, The Effects of High-Velocity Resistance Training and Creatine Supplementation in Untrained Healthy Aging Males, in an oral examination held on December 13, 2018. The following committee members have found the thesis acceptable in form and content, and that the candidate demonstrated satisfactory knowledge of the subject material.

External Examiner:

Supervisor:

Committee Member:

Committee Member:

Chair of Defense:

*via ZOOM Conferencing

${ }^{* *}$ Not present at defense
${ }^{*}$ Dr. Michaela Devries-About, University of Waterloo

Dr. Darren Candow, Faculty of Kinesiology \& Health Studies

Dr. Paul Bruno, Faculty of Kinesiology \& Health Studies

Dr. Brad Shoenfeld, Adjunct

Dr. Wallace Lockhart, Faculty of Business Administration 


\begin{abstract}
The purpose was to investigate the effects of high-velocity resistance training (HVRT) and creatine supplementation on muscle thickness and muscle performance in untrained healthy aging males. Participants were randomized to one of two groups: creatine (CR: n $=12,59.0 \pm 7.0 \mathrm{yrs}, 94.8 \pm 14.3 \mathrm{~kg}, 176.4 \pm 8.6 \mathrm{~cm} ; 0.1 \mathrm{~g} / \mathrm{kg} /$ day of creatine) or placebo (PLA: $\mathrm{n}=12,58.1 \pm 5.8 \mathrm{yrs}, 92.0 \pm 23.3 \mathrm{~kg}, 176.4 \pm 8.6 \mathrm{~cm} ; 0.1 \mathrm{~g} / \mathrm{kg} /$ day of maltodextrin) during 8-weeks of HVRT. Prior to and following training and supplementation, assessments were made for muscle thickness (elbow and knee flexors and extensors), strength (1-repetition maximum for leg-press and chest-press), peak torque (knee flexion and extension), and tasks of functionality (balance and walking speed). There was a significant increase over time for all measures of muscle thickness ( $p$ $<0.001)$, strength $(\mathrm{p}<0.001)$ and relative strength $(\mathrm{kg} / \mathrm{cm} ; \mathrm{p}<0.001)$. There was a time main effect for knee flexion peak torque $(1.05$ and $3.14 \mathrm{rad} / \mathrm{s} ; \mathrm{p}<0.001)$ and knee flexion and extension peak torque combined at $3.14 \mathrm{rad} / \mathrm{s}(\mathrm{p}=0.045)$. There was a time main effect for relative peak torque $(\mathrm{Nm} / \mathrm{cm})$ for knee flexion at $1.05 \mathrm{rad} / \mathrm{s}(\mathrm{p}=0.005)$ and $3.14 \mathrm{rad} / \mathrm{s}(\mathrm{p}=0.007)$, knee extension at $1.05 \mathrm{rad} / \mathrm{s}(\mathrm{p}=0.021)$, and knee flexion and extension combined at $3.14 \mathrm{rad} / \mathrm{s}(\mathrm{p}=0.045)$. There was a decrease in time to complete the balance board task $(p=0.017)$. There was a group $x$ time interaction for leg-press strength $(p=0.044)$ and total lower-body strength $(p=0.039)$. The CR group experienced greater gains (leg-press: mean absolute change: $144.50 \mathrm{~kg} ; 95 \%$ CI [90.12, 198.87]); total lower-body: mean absolute change: $204.75 \mathrm{~kg}$; 95\% CI [145.51, 263.98]) compared to the PLA group (leg-press: mean absolute change: $83.91 \mathrm{~kg}$; 95\% CI [53.00, 114.82]; total lower-body: mean absolute change: $133.58 \mathrm{~kg}$; 95\% CI [93.92, 173.24]). In
\end{abstract}


conclusion, HVRT is an effective intervention to increase muscle thickness, strength, and some measures of peak torque and functionality in untrained, healthy aging males. Creatine supplementation further augmented gains in leg-press and total lower-body strength.

Key words: Lean Tissue Mass, Strength, Power, Functionality 


\section{Acknowledgements}

First, I would like to send the sincerest gratitude to my family: my mother Iwona, my brother Dominic and Wayne. Thank you to each of you for all your continued support throughout my entire academic career and most notably while pursuing graduate studies. Next, my sincerest thank you goes to Dr. Darren Candow. I am forever indebted to him for taking me on as a student and consistently pushing me beyond my comfort zone and holding me accountable to develop and execute a high-quality research project that he is known for.

Third, thank you to Karolina Grzyb and Sara Butchart, the other members of the research team. If it wasn't for their consistent hard work, dedication and strive for absolute perfection, this project wouldn't have been completed as quickly and efficiently as it was. Fourth, thank you to my committee members Dr. Brad Schoenfeld and Dr. Paul Bruno. Your insight and expertise ensured that this project was created and executed to the highest calibre.

Finally, thank you to each of the participants that volunteered their time to participate in this research study. Your contagious energy and continued effort during the duration of this project made it exceptionally fulfilling. 


\section{Table of Contents}

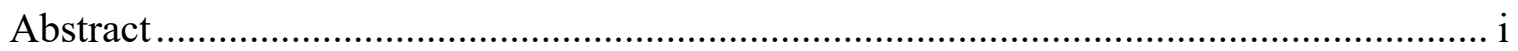

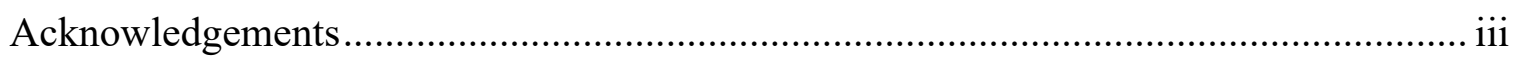

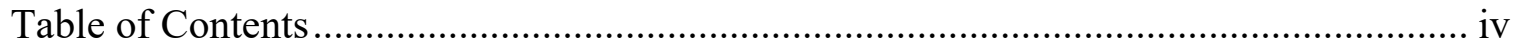

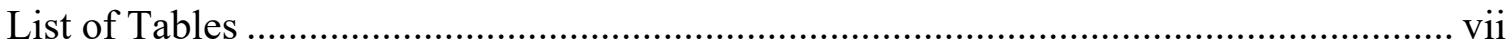

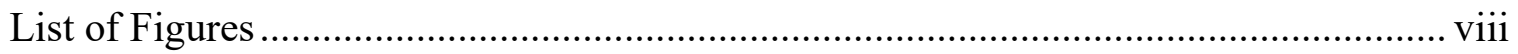

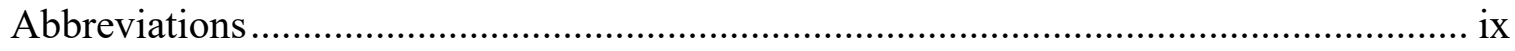

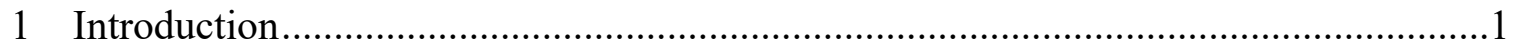

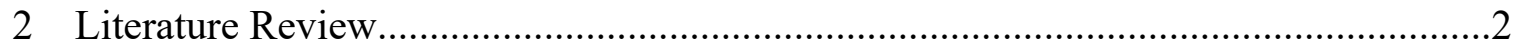

2.1 Aging Muscle Morphology .....................................................................2

2.2 The Role of Oxidative Stress ............................................................

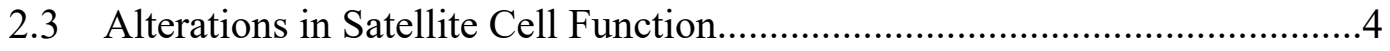

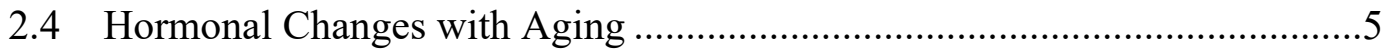

2.5 Anabolic Resistance and Mammalian Target of Rapamycin........................

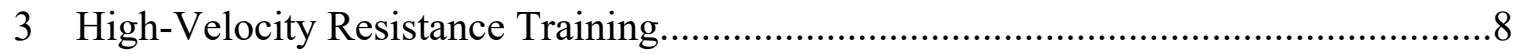

4 Creatine and Potential Mechanistic Actions .........................................................10

4.1 High-Energy Phosphate Metabolism ........................................................10

4.2 Muscle Protein Kinetics and Inflammation .............................................12

4.3 Creatine and Resistance Training in Aging Adults ..................................13

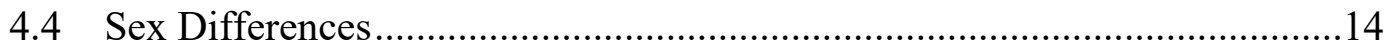

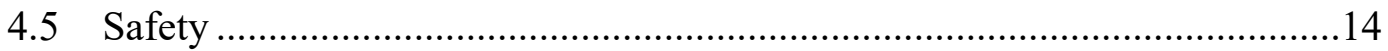

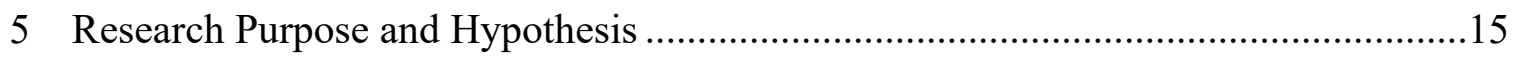

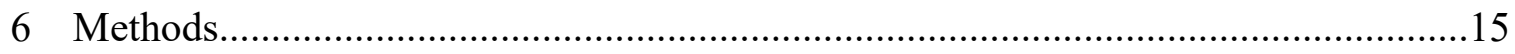




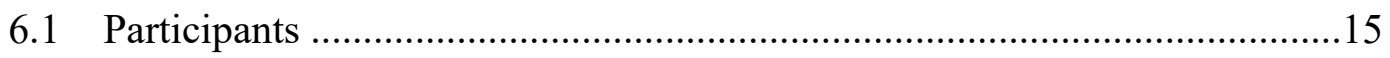

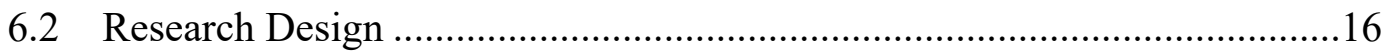

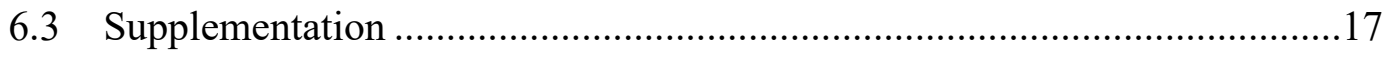

6.4 High-velocity Resistance Training Program..................................................18

6.5 Primary Dependent Variables ...................................................................19

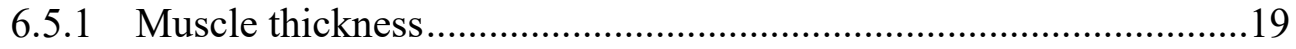

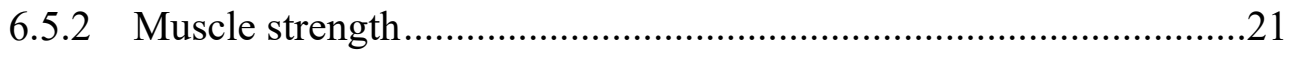

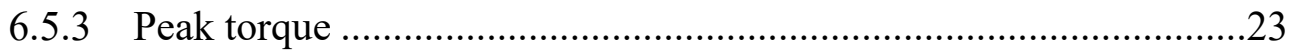

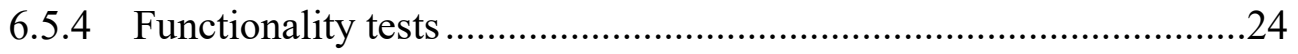

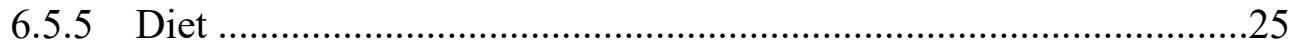

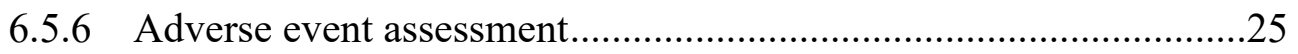

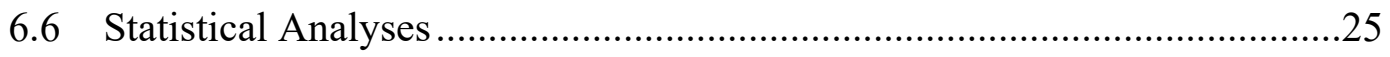

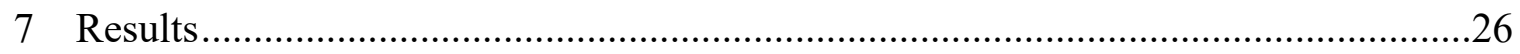

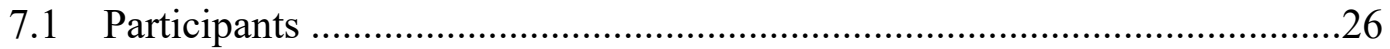

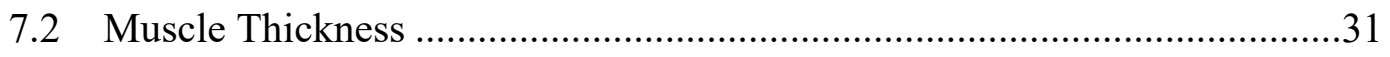

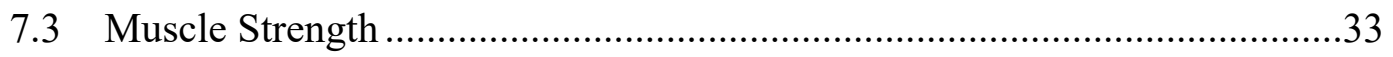

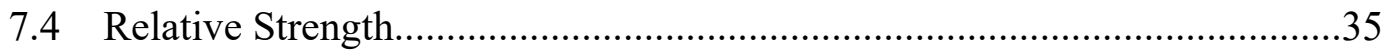

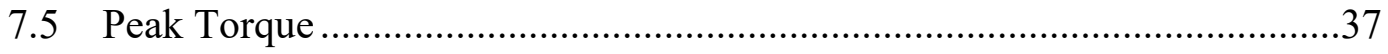

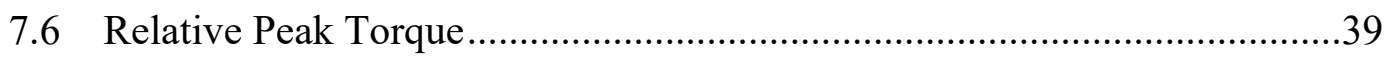

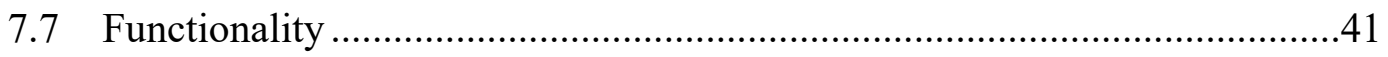

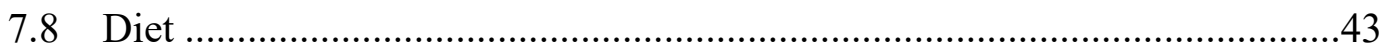

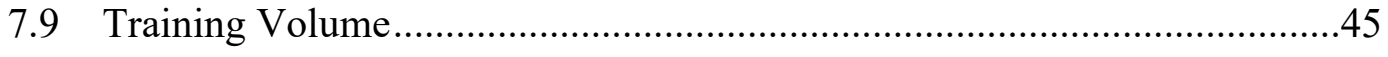

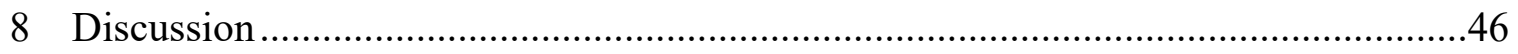

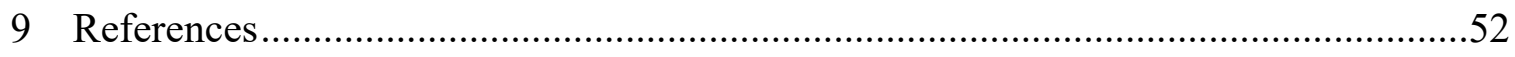




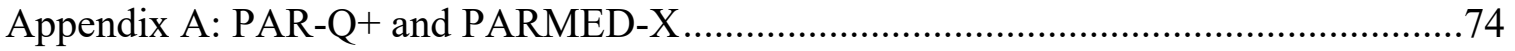

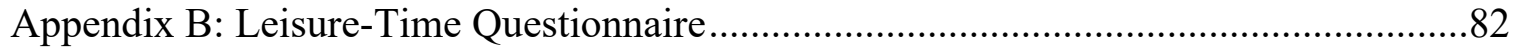

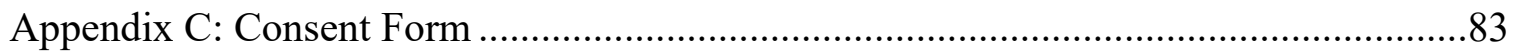

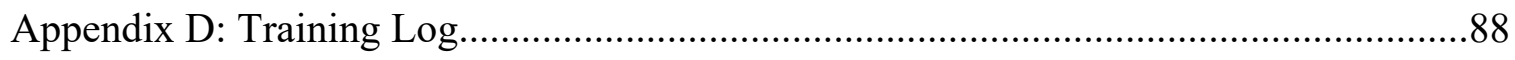

Appendix E: Supplement Compliance Log .......................................................... 90

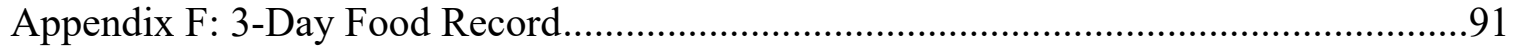

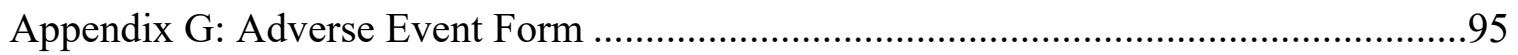

Appendix H: Creatine Purity Certificate of Analysis ............................................. 97 


\section{List of Tables}

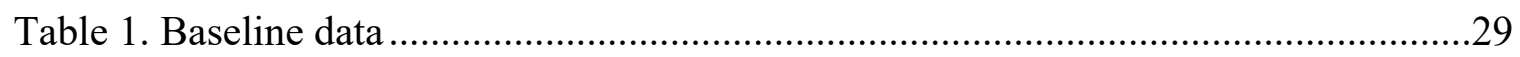

Table 2. Mean Absolute Changes (95\% CI) From Baseline to 8 weeks for Muscle

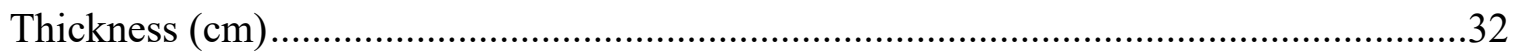

Table 3. Mean Absolute Changes (95\% CI) From Baseline to 8 weeks for Muscle

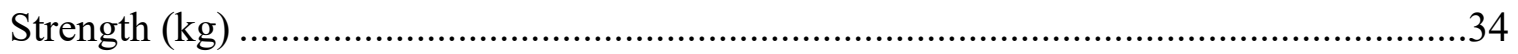

Table 4. Mean Absolute Changes (95\% CI) From Baseline to 8 weeks for Relative

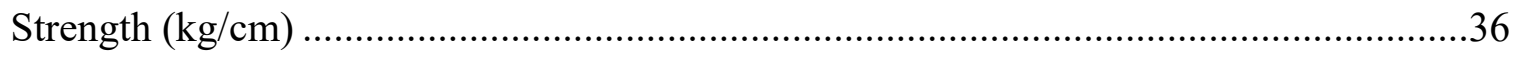

Table 5. Mean Absolute Changes (95\% CI) From Baseline to 8 weeks for Peak Torque

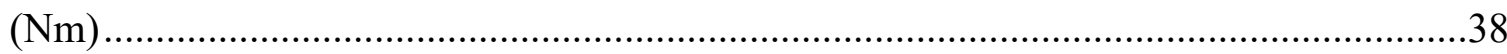

Table 6. Mean Absolute Changes (95\% CI) From Baseline to 8 weeks for Relative Peak

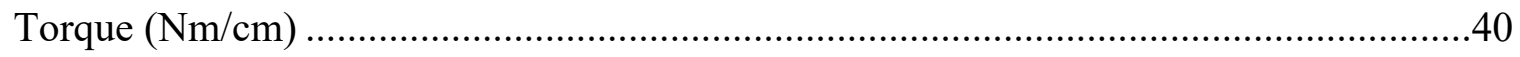

Table 7. Mean Absolute Changes (95\% CI) From Baseline to 8 weeks for Tasks of Functionality

Table 8. Mean Absolute Changes $(95 \% \mathrm{CI})$ From Baseline to 8 weeks for Total Calories (kcal/day), Macronutrients (grams/day) and Relative Protein (g/kg body mass). 


\section{List of Figures}

Figure 1. Summary of recruitment, allocation and analyses........................................27 


\section{Abbreviations}

ADP - adenosine disphosphate

ANCOVA - analysis of covariance

ANOVA - analysis of variance

ATP - adenosine triphosphate

CK - creatine kinase

$\mathrm{Cr}$ - creatine

DHEA - dehydroepiandrosterone

DHEAS - dehydroepiandrosterone sulfate

EWGSOP2 - European Working Group on Sarcopenia in Older People 2

GHRH - growth hormone releasing hormone

HVRT - high-velocity resistance training

IL-6 - interleukin 6

MGF - mechano-growth factor

MPS - muscle protein synthesis

mTOR - mammalian target of rapamycin

ROS - reactive oxygen species

PAR-Q+ - Physical Activity Readiness Questionnaire

$\mathrm{PCr}$ - phosophocreatine

$\mathrm{Pi}$ - inorganic phosphate

PLA - placebo

TNF- $\alpha$ - tumor necrosis factor alpha

1RM - one repetition max 


\section{Introduction}

The European Working Group on Sarcopenia in Older People (EWGSOP2) has recently defined sarcopenia as a muscle disease (ICD-10-MC Diagnosis Code) characterized by low muscle strength, muscle mass and functionality (Cruz-Jentoft et al., 2018). Typically, adults lose between $1-2 \%$ of their total muscle mass per year after the age of 50 which corresponds to a $1.5 \%$ decrease in maximal strength (for review see Abellan van Kan, 2009). Direct and indirect healthcare costs associated with sarcopenia are estimated to be $\$ 18.5$ billion in the United States alone (Beaudart et al., 2014). Furthermore, Janssen et al. (2004) concluded that a $10 \%$ reduction in the prevalence of sarcopenia could result in a savings of $\$ 1.1$ billion per year, substantiating the need for interventions aimed at combating sarcopenia. Factors contributing to sarcopenia include changes in muscle biology, oxidative stress, satellite cell function, hormonal regulation, nutrition, and physical activity (Cruz-Jentoft et al., 2014, 2010; Karakelides \& Nair, 2005; Marzetti et al., 2017). From a healthy aging perspective, lifestyle interventions which decrease sarcopenia are clinically significant.

One potential intervention which may benefit aging muscle is high-velocity resistance training (HVRT). HVRT is characterized as a resistance training modality where an external load is contracted at a maximal velocity (Fielding et al., 2002; Reid \& Fielding, 2012). Although muscle power and strength are important components of health-related fitness, muscle power appears to be the best indicator of functionality (Bassey et al., 1992; Bean et al., 2004; Bean et al., 2002; Cruz-Jentoft et al., 2010; Foldvari et al., 2000). Unfortunately, the biological process of aging has a negative effect on muscle performance which may be the result of a reduction in high threshold 
muscle fibers (i.e. type II) (Aagaard et al., 2010; Cruz-Jentoft et al., 2010; Fielding et al., 2002). Type II muscle fibers are responsible for high force generation and appear to be more vulnerable to atrophy than type I fibers with aging (Evans \& Lexell, 1995). Theoretically, HVRT may recruit existing higher threshold motor units which could maintain or increase muscle performance in aging adults.

Another intervention which may have beneficial effects on aging muscle is creatine supplementation. Creatine, a naturally occurring nitrogenous compound found primarily in red meat and seafood, has been shown to increase aging muscle mass, strength, and tasks of functionality when combined with resistance training (for metaanalysis reviews see Candow et al., 2014; Chilibeck et al., 2017; Devries and Phillips, 2014). Mechanistically, creatine may influence high-energy phosphate metabolism, muscle protein kinetics and inflammation (for reviews see Candow and Chilibeck, 2008; Candow et al., 2014; 2012; Chilibeck et al., 2017; Gualano et al., 2016; Kreider et al., 2017).

Despite the potential beneficial effects of HRVT and creatine supplementation on aging muscle, no study has examined the combined effects of HVRT and creatine supplementation. Therefore, the purpose of this thesis was to examine the effects HVRT and creatine supplementation on muscle thickness, muscle performance, and tasks of functionality in untrained healthy aging males.

\section{Literature Review}

\subsection{Aging Muscle Morphology}

Typically, adults lose between $1-2 \%$ of their total muscle mass per year after the age of 50 which corresponds to a $1.5 \%$ decrease in maximal strength (for review see 
Abellan van Kan, 2009). A main contributing factor of this age-related muscle loss is the reduction in type II muscle fibers (Evans \& Lexell, 1995). Three main isoforms of myosin heavy chain (MHC) exist in human skeletal muscle (MHC I, MHC IIa, MHC IIx) (Karakelides, \& Nair, 2005). MHC I mRNA levels appear to remain relatively constant with aging, but mRNA levels of MHC IIa and MHC IIx decrease, ultimately leading to a preferential loss of muscle fibers responsible for high force production (Balagopal et al., 2001).

Muscle contractile properties may also be jeopardized with aging. Clark and Manini, (2012, 2008), suggested that the age-related loss of muscle force production is linked to alterations in neural and mechanical factors affecting muscle biology. Contraction time is slower and relaxation time is longer in aging muscle (Fielding, 2012; McKinnon et al., 2017). This decreased speed of contraction may be due to impaired functioning and decreased volume of the sarcoplasmic reticulum, changes to myofibrillar contractile proteins, and a reduction in the number of T-tubule dihydropyridine receptors (Fielding, 2012; Scelsi et al., 1980). Interestingly, resistance training has been reported to positively influence muscle mechanics and increase the density of the sarcoplasmic reticulum and T-tubules and increase the rates of myofibrillar muscle protein synthesis (MPS) (for reviews see Boonyarom \& Inui, 2006; Schoenfeld, 2010; Toigo, \& Boutellier, 2006). Other architectural changes potentially contributing to the decrease in muscle contractile properties with aging include reductions in the pennation angle and contractile tissue along tendons (Narici \& Maffulli, 2010; Thom et al., 2007). Furthermore, a rearrangement of muscle fiber type by way of the denervation-innervation process may negatively impact maximal force production as type II muscle fibers transition into type I muscle fibers (Mosole et al., 


\subsection{The Role of Oxidative Stress}

Chronic oxidative stress has been identified as a potential risk factor for sarcopenia (Johnston et al., 2007). The mitochondrial or oxidative stress theory of aging stipulates that a decreased ability to maintain oxidative homeostasis exists with increasing age resulting in cellular damage due to the accumulation of reactive oxygen species (ROS) (Johnston et al., 2007). Chronically high levels of ROS can damage and alter DNA, lipids, and proteins which result in apoptosis (Bouzid et al., 2015; Bowen et al., 2015). Type II muscle fibers are particularly susceptible to ROS as type II fibers have decreased oxidative enzymes and increased metabolic demand when compared to type I fibers (Gordon et al., 2004). Although chronically high levels of ROS appear to negatively affect skeletal muscle, a growing body of evidence suggests that acute increases in ROS in response to contractile activity (i.e. resistance training) may activate redox-sensitive signaling cascades in skeletal muscle which may influence hypertrophic adaptations (Gomes et al., 2012; Niess \& Simon, 2007). Furthermore, the age-related increase in tumor necrosis factor alpha (TNF- $\alpha$ ) and interleukin 6 (IL-6) expression may increase the rates of muscle protein catabolism ultimately leading to muscle atrophy and/or loss in strength and power (Bales \& Ritchie, 2002; Bautmans \& Mets, 2005; Candow, 2011; Ladner et al., 2003).

\subsection{Alterations in Satellite Cell Function}

Satellite cells are located between the sarcolemma and basement membrane and play an important role in the hypertrophic response, repair, and growth of skeletal muscle 
fibers (Barton-Davis et al., 1999; Olsen et al., 2006). These undifferentiated and mononucleated cells typically remain dormant until they are activated from mechanical stimuli such as resistance training. Once activated, satellite cells re-enter the cell cycle and proliferate and differentiate to form new muscle fibers (Ryall et al., 2008; Sabourin, \& Rudnicki, 2000; Toigo \& Boutellier, 2006). The primary benefit of satellite cells with respect to muscular hypertrophy appears to be their ability to donate nuclei to muscle fibers, facilitating the synthesis of contractile proteins by increasing the myonuclear domain (Moss \& Leblond, 1971; Schoenfeld, 2010). Furthermore, satellite cells contain myogenic regulatory factors (i.e. myogenin, MRF4, MyoD, and Myf5) that bind to sequence DNA during myogenesis and ultimately contribute to muscle hypertrophy (Sabourin, \& Rudnicki, 2000). Unfortunately, aging adults appear to exhibit reduced quantities of myogenic satellite cells which may help explain the age-related loss of skeletal muscle mass (Kadi et al., 2004; Sajko et al., 2004).

\subsection{Hormonal Changes with Aging}

The biological process of aging can affect the secretion, bioavailability, and tissue response to hormones (Karakelides, \& Nair, 2005). Dehydroepiandrosterone (DHEA), dehydroepiandrosterone sulfate (DHEAS), testosterone, growth hormone $(\mathrm{GH})$, and insulin-like growth factor (IGF-1) have all been reported to decrease with aging and are believed to be involved in the pathophysiology of sarcopenia (Karakelides, \& Nair, 2005;

Roubenoff, 2003). Testosterone appears to affect skeletal muscle, independent of exercise (Buresh et al., 2009). Testosterone increases the rates of muscle protein synthesis and the activation and proliferation of satellite cells (Buresh et al., 2009; Sinha-Hikim et al., 
2006) which may help explain their strong correlation to muscle mass and strength gains (Baumgartner et al., 1999; Karakelides, \& Nair, 2005).

$\mathrm{GH}$ is a non-selective growth agent with widespread receptors found in various human tissues (Waters et al., 1999). GH levels have been shown to increase following an acute bout of exercise as well during sleep (Kraemer \& Ratamess, 2005; Schoenfeld, 2010). GH provides an anabolic stimulus and is believed to initiate a sequence of growth factors and their receptors (Waters et al., 1999). The observed decline of GH with aging is postulated to be secondary to the decrease in growth hormone releasing hormone (GHRH) (Karakelides, \& Nair, 2005).

Insulin-like growth factor (IGF) is often considered to be one of the most important anabolic hormones for muscle hypertrophy (Schoenfeld, 2010). Several isoforms of IGF-1 have been identified: IGF-1Ea, IGF-1Eb, and IGF-1Ec (Schoenfeld, 2010). IGF-1Ec is activated by mechanical stimuli and is referred to as mechano-growth factor (MGF) (Hameed et al., 2004; Schoenfeld, 2010). MGF likely plays a crucial role in the repair of muscle tissue and appears to be expressed following mechanical loading (i.e. resistance training) and/or damage to skeletal muscle (Owino et al., 2001; Zanou \& Gailly, 2013). In response to muscle injury, the expression of MGF is upregulated and appears to be closely related to satellite cell activation (Zanou \& Gailly, 2013). Following mRNA splicing, MGF alters its expression to IGF-IEa, facilitating myogenesis and skeletal muscle regeneration (Owino et al., 2001; Zanou \& Gailly, 2013). Receptors for insulin-like growth factors are found on myofibers as well as satellite cells (Barton-Davis et al., 1999). During resistance training, muscle tissue produces IGF-1 which provides a significant anabolic stimulus for increasing the rates of MPS (Barton-Davis et al., 1999; 
Goldspink, 2005). The age-related decrease in IGF-1 is likely a contributing factor to sarcopenia.

\subsection{Anabolic Resistance and Mammalian Target of Rapamycin}

Skeletal muscle is in a constant state of protein turnover, undergoing protein catabolism and protein synthesis (Rennie \& Tipton, 2000). In order for muscle hypertrophy to occur, rates of MPS must exceed the rates of muscle protein catabolism (Rennie \& Tipton, 2000). The anabolic drivers responsible for increasing muscle protein synthesis (e.g. exercise, essential amino acids) appear to be blunted in older adults (Rennie, 2009). Kumar et al., (2009) observed blunted rates of MPS at 1-2 hours postresistance exercise in older participants but not young. An increased training volume (i.e. sets $\mathrm{x}$ reps $\mathrm{x}$ load) may be required to elicit a maximal muscle protein synthetic response. Furthermore, the rate of MPS following ingestion of dietary protein appears to also be blunted in older adults and require a larger dose than their younger counterparts to achieve a similar increase in the rates of MPS (Breen \& Phillips, 2011).

There may be an increase in muscle protein catabolism with increasing age which may result in atrophy of muscle tissue (Karakelides, \& Nair, 2005). The age-related loss of skeletal muscle may also be linked to impaired signaling of the Akt/mammalian target of rapamycin (mTOR) pathway (de Bandt, 2016; Fry et al., 2011). mTOR is responsible for regulating cell growth and proliferation, muscle hypertrophy, ribosome biogenesis, and energy metabolism by activating and inhibiting various anabolic and catabolic processes (Laplante \& Sabatini, 2012; Sarbassov et al., 2005). mTOR has been identified as a main regulator of messenger ribonucleic acid (mRNA) translation and is upregulated by anabolic stimuli such as resistance training (Little \& Phillips, 2009; Sandri, 2008; 
Schoenfeld, 2010). Activation of the mTOR pathway and its downstream targets of $4 \mathrm{E}$ binding protein 1 (4E-BP1), 70-kDA S6 protein kinase (p70 s6k), and protein S6 kinase (S6K1 and S6K2), have been identified as important modulators of MPS in response to resistance training (Fry et al., 2011; Little \& Phillips, 2009). While in a nonphosphorylated state, 4E-BP1 binds to eukaryotic translation initiation factor 4E (eIF4E), suppressing mRNA translation. Once 4E-BP1 is phosphorylated by mTOR, eIF-4E is released and used to restore translation (Sarbassov et al., 2005). Two genes of S6 kinase are found in mammals, ribosomal protein S6 kinase beta-1 (S6K1) and ribosomal protein S6 kinase beta-2 (S6K2), and although both are activated by mTOR, the exact mechanisms and how they regulate cell size remains to be elucidated (Sarbassov et al., 2005).

Unfortunately, the biological process of aging appears to have a negative effect on mTOR signaling and MPS. For example, following an acute bout of resistance training, Fry et al. (2011) showed that aging males $(n=16 ; 70 \pm 2$ yrs $)$ experienced no change in mTOR, S6K1, 4E-BP1 or MPS. Furthermore, Kumar et al. (2009) observed a reduced rate in MPS two hours post-exercise in aging adults compared to younger adults. Results across studies suggest that aging adults experience anabolic resistance to resistance training which may be a contributing factor to sarcopenia.

\section{High-Velocity Resistance Training}

Muscle power and strength are important components of health-related fitness (Cheema et al., 2014; Davies et al., 2017; de Vos et al., 2005; Fielding et al., 2002; Newman et al., 2006). Although muscle strength is relatively preserved into the fifth decade of life, the ability to generate forceful contractions quickly (i.e. muscle power) is 
diminished twice as fast (Aagaard et al., 2010; Cruz-Jentoft et al., 2010; Fielding et al., 2002; Skelton et al., 1994). From a neurophysiological perspective, the motor unit originates in the motor cortex of the brain and terminates on the muscle fiber (Sale, 1987). Activity in the motor cortex intensifies as the level of force increases, which amplifies motor unit firing rates and frequencies, and ultimately increases the force and rate of muscle contractions (Dettmers, 1996; Sale, 2008). Low threshold motor units (type I fibers) have lower force generating capabilities than higher threshold motor units (type II fibers) (Sale, 1988). Moreover, type II fibers generate four to six times the power of type I fibers per unit of mass (Trappe et al., 2003). Motor units are recruited based on Hennemann's size principle which stipulates that in order to recruit high threshold motor units, lower threshold motor units must first be recruited (Sale, 1988). According to this principle, type I (slow twitch) and type II (fast twitch) fibers are typically recruited sequentially. This suggests that in order to achieve maximal motor unit recruitment, the stimulus or exercise intensity must be relatively high or fatiguing. HVRT has been shown to recruit and induce type II hypertrophy in older adults, leading to concomitant increases in muscular strength and muscular power (Häkkinen et al., 2001; Nogueira et al., 2009). It is important to note, that although concomitant increases in muscular strength and muscular power are observed following resistance training, the increases in muscle power following HVRT are significantly higher than traditional low-velocity resistance training, with similar increases in muscle strength using either modality (de Vos et al., 2005; Earles et al., 2001; Fielding et al., 2002; Marsh et al., 2009; Reid and Fielding, 2012; Reid et al., 2008). For the purpose of this thesis, power will be defined as the product of force and velocity (of shortening) (Foldvari et al., 2000). 


\section{Creatine and Potential Mechanistic Actions}

Creatine is a nitrogenous compound naturally produced in the body from reactions involving the amino acids glycine, arginine and methionine in the liver and kidney and is also found primarily in in red meat and seafood (Barcelos et al., 2016; Gualano et al., 2010; Wyss \& Kaddurah-Daouk, 2000). The majority of creatine is stored in skeletal muscle (Gualano et al., 2010; Wyss \& Kaddurah-Daouk, 2000), with two thirds being PCr while one third is free creatine (Cr; Kreider et al., 2017). A typical omnivorous diet contains approximately 1-2 grams per day of creatine leaving creatine stores around 60-80\% saturated (Kreider et al., 2017; Brosnan \& Brosnan, 2016). PCr concentrations are slightly higher (5-15\%) in type II versus type I muscle fibers and utilize PCr to a greater extent (Greenhaff et al., 1994; Terjung et al., 2000). Following creatine supplementation, both type I and type II fibers exhibit an increase in total PCr and $\mathrm{Cr}$ concentrations, however, the greatest accumulation is observed in type II fibers (Casey et al., 1996a; 1996b). Mechanistically, creatine may have a beneficial effect on muscle biology by influencing high-energy phosphate metabolism, muscle protein kinetics and inflammation (for reviews see Candow and Chilibeck, 2008; Candow et al., 2014; 2012; Chilibeck et al., 2017; Gualano et al., 2016; Kreider et al., 2017).

\subsection{High-Energy Phosphate Metabolism}

Creatine is the main component of phosphocreatine (PCr), a high-energy phosphate compound responsible for supplying energy during skeletal muscle contractions (Wyss \& Kaddurah-Daouk, 2000). The main role of creatine is to combine with inorganic phosphate $(\mathrm{Pi})$ to create $\mathrm{PCr}$ through the creatine kinase $(\mathrm{CK})$ reversible 
reaction (Kreider et al., 2017). PCr aids in resynthesizing adenosine triphosphate (ATP) from adenosine disphosphate (ADP) by providing free energy from the hydrolysis of $\mathrm{PCr}$ into its components of $\mathrm{Pi}$ and $\mathrm{Cr}$ during skeletal muscle contraction (Candow et al., 2014; Kreider et al., 2017; Schlattner et al., 2016; Wyss \& Kaddurah-Daouk, 2000). The PCr energy shuttle connects the sites of ATP production (i.e. glycolysis and oxidative phosphorylation) with the sites of ATP utilization (e.g. myosin cross-bridge sites) and plays an essential role in the regulation of muscle contraction (Kreider et al., 2017; Volek et al., 2008). Cr has the ability to diffuse into the mitochondria, couple with ATP produced from glycolysis and oxidative phosphorylation, and recycle (shuttle) back into the cytosol to maintain metabolic demand (Kreider et al., 2017). The shuttling of $\mathrm{Cr}$ from the mitochondria into the cytosol is performed using active transport, requiring the creatine transporter CRTR (Kreider et al., 2017; Santacruz \& Jacobs, 2016). Once in the cytosol, creatine and its isoforms (cytosolic and glycolytic $\mathrm{CK}$ ) meet energy requirements by maintaining ATP utilization and the cytosolic ATP/ADP ratios by rephosphorylating ADP into ATP (Kreider et al., 2017; Wallimann et al., 2011). The PCr energy shuttle has been identified as a key regulator of energy metabolism that may be positively influenced and optimized with creatine supplementation (Candow et al., 2014; 2011; Kreider et al., 2017). There is a decrease in total intramuscular creatine levels (i.e. $\mathrm{Cr}$ and PCr) with aging (Candow et al., 2012; Forsberg et al., 1991; Möller et al., 1980), which may have a negative effect on resistance training capacity (Kreider et al., 2017). Creatine supplementation increases intramuscular creatine stores in aging adults which may enhance PCr resynthesis and high-energy phosphate metabolism leading to greater gains in muscle mass and muscle performance over time. 


\subsection{Muscle Protein Kinetics and Inflammation}

Creatine supplementation has been reported to increase intracellular osmolarity which may upregulate gene and signaling pathways involved in protein synthesis (for reviews see Candow et al., 2012; Chilibeck et al., 2017). Creatine increases mRNA and protein expression of the myogenic transcription factors myogenin and MRF-4 (Willoughby and Rosene 2003) and increases satellite cell number and myonuclei concentration in muscle fibers following resistance exercise (Olsen et al. 2006). Creatine has also been shown to increase Akt/protein kinase B content in humans (Safdar et al. 2008). Akt/Protein kinase B activates $\mathrm{p} 70^{\mathrm{s} 6 \mathrm{k}}$ downstream in the mammalian target of rapamycin (mTOR) muscle protein synthetic pathway (Fujita et al. 2007), a main regulator of muscle hypertrophy.

Creatine supplementation has been reported to affect anabolic hormone production (Burke et al., 2008; Delidicque et al., 2005). Insulin-like growth factor I (IGF1) plays a role in MPS and satellite cell proliferation (Allen \& Boxhorn, 1989). Shortterm creatine supplementation (21g/day) in young males increased IGF-1 mRNA expression at rest and the phosphorylation of anabolic signaling molecules (i.e. 4E-BP1) 24 hours after an acute bout of resistance exercise (Deldicque et al., 2005). Furthermore, Burke et al. (2008) found greater increases in intramuscular IGF-1 content in healthy males and females following 8 weeks of creatine supplementation and resistance training compared to placebo (Burke et al., 2008).

Although creatine supplementation may not directly increase rates of muscle protein synthesis, it may decrease muscle protein catabolism (Parise et al., 2001). In aging males, creatine supplementation decreased the urinary excretion of 3- 
methylhistidine, an indicator of muscle protein catabolism (Johannsymer et al., 2016;

Candow et al., 2008). Furthermore, creatine supplementation reduced the rates of leucine oxidation, an indicator of whole-body protein breakdown, suggesting that creatine supplementation may exhibit anticatabolic characteristics (Parise et al., 2001).

Furthermore, creatine supplementation attenuates reactive and radical species ions (Deminice and Jordao, 2011) and protects against DNA and RNA damage (Fimognari et al. 2009). Therefore, creatine may have anabolic and anti-catabolic effects on muscle biology which over time, may lead to gains in muscle mass and muscle performance.

\subsection{Creatine and Resistance Training in Aging Adults}

Three meta-analyses indicate that creatine must be combined with resistance training to produce significant muscle health benefits in aging adults. In the most comprehensive analysis, Chilibeck et al., (2017) examined the effects of creatine supplementation and placebo during resistance training (7-52 weeks) in 721 aging adults (57-70 years of age) across 22 eligible studies. Results showed that creatine during resistance training increased lean tissue mass (mean difference: $1.37 \mathrm{~kg}, 95 \%$ CI [ 0.97 , 1.76], $\mathrm{p}<0.00001$ ), leg press strength (standardized mean difference: $0.24,95 \% \mathrm{CI}$ $[0.05,0.43], p=0.01$ ) and chest press strength (standardized mean difference: $0.35,95 \%$ CI $[0.16,0.53], \mathrm{p}=0.0002)$ more than placebo and resistance training. Previously, Devries \& Phillips (2014) analyzed over 300 men and women (55-71 years of age) who consumed creatine (3-25 grams) during resistance training (7-26 weeks) across 10 eligible studies. Compared to placebo, creatine significantly increase lean tissue mass (weighted mean difference: $1.33 \mathrm{~kg}, 95 \%$ CI $[0.79,1.86], \mathrm{p}<0.0001$ ), leg press strength (weighted mean difference: $3.25 \mathrm{~kg}, 95 \% \mathrm{CI}[0.47,6.03], \mathrm{p}=0.02$ ) and chest press 
strength (weighted mean difference: $1.74 \mathrm{~kg}, 95 \% \mathrm{CI}[0.56,2.91], \mathrm{p}=0.004$ ) more than placebo and resistance training. Finally, Candow et al. (2014) showed that creatine supplementation $(\sim 0.1-0.3 \mathrm{~g} / \mathrm{kg} ;>6$ weeks $)$ and resistance training in over 300 aging adults increased lean tissue mass (mean difference: $0.94 \mathrm{~kg}, 95 \%$ CI $[0.33,1.54], \mathrm{p}=$ 0.002 ) and chest press strength (standardized mean difference: $0.42,95 \%$ CI $[0.15,0.70]$, $\mathrm{p}=0.0003$ ) more than placebo and resistance training.

\subsection{Sex Differences}

The response to creatine supplementation is inconsistent between males and females (Kreider et al., 2017). Females may not experience the same gains in muscle mass and strength following creatine supplementation and resistance training compared to males (Johannsmeyer et al., 2016; Tarnopolsky \& Maclennan, 2000). Although speculative, females may have higher initial intramuscular creatine stores (free creatine and $\mathrm{PCr}$ ) than males which make them less responsive to supplementation (Forsberg et al., 1991; Johannsmeyer et al., 2016; Tarnopolsky, 2000). Furthermore, creatine appears to have no effect on muscle protein kinetics in females (Parise et al., 2001). Therefore, for the purpose of this thesis, only healthy aging males were recruited.

\subsection{Safety}

A recent position stand paper by the International Society of Sports Nutrition (ISSN) concluded that creatine supplementation poses no greater adverse effects compared to placebo (Kreider et al., 2017). 


\section{Research Purpose and Hypothesis}

The purpose of this thesis was to compare the effects of HVRT and creatine supplementation to HVRT and placebo in untrained healthy aging males. It was hypothesized that HVRT and creatine supplementation would increase muscle thickness, strength, peak torque and tasks of functionality compared to HVRT and placebo.

\section{Methods}

\subsection{Participants}

Males ( $\geq 50$ years of age) who were not previously engaged in supervised resistance training for $\geq 6$ weeks prior to the start of the study were recruited to participate. Recruitment occurred through the University of Regina e-mail server list. A priori power analysis $\left(\mathrm{G}^{*}\right.$ Power v. 3.1.5.1) indicated that 34 participants were required to achieve $80 \%$ statistical power. This calculation was based on effect size (Cohen's $d=$ 0.25), alpha level (0.05), and using a repeated measures: within-between interaction study design (Faul et al., 2007).

Participants were required to complete a Physical Activity Readiness Questionnaire (PAR-Q+) (Appendix A), which assessed an individual's readiness for participation in resistance training. This questionnaire included questions related to heart conditions, angina at rest or during physical exercise, balance, and bone or joint problems that may affect exercise performance. If a participant indicated any of the above conditions, they were required to get medical clearance before starting the study. Participants were required to fill out a leisure time exercise questionnaire (Appendix B), 
which indicated the average number of times that strenuous (i.e. heart beats rapidly), moderate (i.e. not exhausting), and mild exercise (i.e. minimal effort) was performed per week (Godin \& Shephard, 1985). Participants were excluded from the study if they were taking medications that affected muscle biology (i.e. corticoids) or creatine monohydrate $\leq 12$ weeks prior to the start of the study; if they had a history of fragility fractures; diseases that are known to affect muscle biology; if they suffered from severe osteoarthritis; had pre-existing kidney or liver abnormalities, if they were vegetarian; or if they were planning to travel during the study period for $\geq 2$ weeks duration at a time. Participants were instructed not to change their diet or engage in additional physical activity that was not part of their normal daily routine or consume non-steroidal antiinflammatory drugs during the study, as these interventions could affect MPS (Trappe et al., 2002). The Research Ethics Board at the University of Regina approved the study and participants were informed of the risks and purposes of the study before their written consent was obtained (Appendix C).

\subsection{Research Design}

This randomized control trial (ClinicalTrials.gov Identifier: NCT03530202) involved a double-blind, repeated measures design. In order to minimize difference between groups, participants were matched according to age and body mass. After exclusion criteria was applied, participants were randomized on a 1:1 basis to supplement with creatine monohydrate (CR) or placebo (PLA; corn-starch maltodextrin) during 8 weeks of HRVT. The primary dependent variables measured at baseline and after the intervention included: (1) muscle thickness (elbow and knee flexors and extensors), (2) muscle strength (1-RM leg press, chest press, and elbow and knee flexion and extension), 
(3) peak torque (knee flexion and extension at $1.05 \mathrm{rad} / \mathrm{s}$ and $3.14 \mathrm{rad} / \mathrm{s}$ ), and (4) tasks of functionality (walking speed and balance). In addition, participants were required to complete a 3-day food diary (Appendix G) prior to the start of the study and during the final week of training and supplementation to determine whether total energy (kcal) and macronutrient intake changed over time. Muscle thickness, tasks of functionality and peak torque were assessed 48 hours prior to the assessment of muscle strength.

\subsection{Supplementation}

Creatine (Creapure ${ }^{\circledR}$ AlzChem Trostberg GmbH, Germany) and placebo (Globe Plus 10 DE Maltodextrin, Univar Canada) were administered in powder form. Both supplements were administered at a dose of $0.1 \mathrm{~g} / \mathrm{kg} /$ day. This dosage has previously shown to be effective for increasing muscle mass in aging males without resulting in adverse effects (Candow et al., 2008). Contents of the creatine monohydrate powder (Creapure, AlzChem AG, Trostberg, Germany) were verified by testing in an independent laboratory (The Cary Company, Addison, Ill., USA) and purity was established as $>99.9 \%$ (Appendix H). Creatine and placebo were similar in taste, texture, color, and appearance. An individual, who was not involved in any other aspect of the study, was responsible for mixing and packaging the supplements in plastic bags and preparing individual study kits. Each study kit contained the participants supplement for the duration of the study, detailed supplementation instructions, measuring spoons and a supplement compliance log. On training days, participants mixed their supplement powder in water and consumed the beverage within 5 minutes following each training session. A recent meta-analysis showed that post-exercise creatine supplementation leads to significant gains in muscle mass and strength (Forbes and Candow, 2018). On non- 
training days, participants consumed their supplement at their leisure. Following competition of the study, each participant was asked whether they thought they were administered creatine, placebo or unsure what supplement they consumed.

\subsection{High-Velocity Resistance Training Program}

Prior to the start of supplementation, participants performed three supervised familiarization resistance-training sessions in the Aging Muscle and Bone Health Laboratory, University of Regina. Participants were shown how to properly breathe, use the equipment, and perform repetitions to volitional fatigue. Machine-based resistance training equipment (Pulse Exercise Systems Inc., Winnipeg, Canada) was chosen because it is considered safer and easier to use than free-weights, especially for untrained individuals (Ratamess et al., 2009). During the first familiarization session, participants performed 2 sets for each exercise; 3 sets during the second familiarization session and 34 sets during the final familiarization session. Exercises performed in the following order were leg press, knee extension, knee flexion, chest press, elbow extension and elbow flexion. Participants performed the concentric phase of each muscle contraction as 'quickly as possible' and performed the eccentric phase in 2 seconds (in accordance to a metronome). Participants performed 4 sets at $80 \%$ baseline $1-\mathrm{RM}$ to volitional fatigue for the leg press and knee flexion and extension, and 3 sets at $80 \%$ baseline $1-\mathrm{RM}$ to volitional fatigue for the chest press and elbow flexion and extension, 2 days per week, on non-consecutive days, for 8 weeks. Two-minutes of rest separated each set. $80 \% 1$ RM was chosen as the resistance training intensity based on the findings of de Vos et al. (2005) who showed that HVRT performed at 80\% 1-RM increased muscle strength more than $20 \% 1-\mathrm{RM}$ or $50 \% 1-\mathrm{RM}$. The exercise load did not change during the 8 weeks of 
training and supplementation, as the purpose of the study was to overload the upper- and lower-body musculature by increasing the number of repetitions performed to volitional fatigue. Participants performed more sets for the lower-body because lower-body muscle groups exhibit a greater strength deficit (Candow and Chilibeck, 2005) and an attenuated muscle hypertrophic response to resistance training compared to upper-body muscle groups (Weisgarber et al., 2015). Training logs (Appendix D) were completed by each participant to ensure adherence and compliance to the study and to determine total training volume (weight $\mathrm{x}$ sets $\mathrm{x}$ repetitions).

\subsection{Primary Dependent Variables}

6.5.1 Muscle thickness. Muscle thickness measurements (right side) were taken for the elbow and knee flexors and extensors using a B-Mode ultrasound (LOGIQ e, GE Medical Systems, China). An 8-MHz scanning transducer head was placed on the measurement site, perpendicular to the muscle area. Water-soluble transmission gel (EcoGel 200, Eco-Med Pharmaceutical Inc., Mississauga, Ontario, Canada) was placed on the measurement site to provide acoustic contact with the surface of the muscle. When the clear muscle image on the monitor screen was frozen, a cursor was enabled to quantify muscle thickness $(\mathrm{cm})$ at three sites: proximal, mid and distal, as determined by divisions $(1 \mathrm{~cm})$ on the monitor screen. Muscle thickness measurements were determined from the monitor screen by measuring the distance from the bottom of the subcutaneous adipose layer to the surface of the humerus for the elbow flexors and extensors and to the surface of the femur for the knee flexors and extensors. Three muscle thickness measurements were taken at each of the four muscle group sites. The values at each of 
three sites were averaged to quantify one muscle thickness value that was used for analysis.

To measure elbow flexor and extensor muscle thickness, a small mark was drawn on the lateral side of the arm to indicate $65 \%$ of the distance down from the acromion process to the olecranon process (Farthing \& Chilibeck, 2003). A tape measure was wrapped around the arm at the $65 \%$ mark and used as a reference and another mark placed on the bulk of the elbow flexors and extensors where the center of the ultrasound probe was placed. To measure elbow flexor muscle thickness, each participant placed their right arm flat on a table with the belly of the biceps facing upwards and the forearm supinated. To measure elbow extensor muscle thickness, participants were instructed to stand with their back facing the researcher with elbows relaxed and extended.

To measure knee flexor and extensor muscle group thickness, a small mark was drawn on the lateral side of the leg to indicate $70 \%$ of the distance down from the greater trochanter to the lateral condyle of the tibia (Abe et al., 2001). A tape measure was wrapped around the leg at the $70 \%$ mark and used to mark another reference point on the bulk of the knee flexors and extensors where the center of the ultrasound was placed. To measure knee flexor muscle thickness, each participant was positioned prone on the table with both legs extended and relaxed. To measure knee extensor muscle thickness, each participant was positioned on a table in a seated position with their leg extended and relaxed.

Precise markings using a permanent marker were made on a transparency film sheet to ensure that the exact identical site was measured before and after the resistance training program. Reproducibility of muscle thickness measurements was determined by assessing 10 participants measured on two separate days ( $>24$ hours) and determining 
the coefficient of variation (defined as the square root of the between-test variance [standard deviation], divided by the combined mean of test days 1 and 2, multiplied by $100 \%$ ). The coefficients of variation for muscle thickness measurements were $2.4 \%$ (elbow flexors), $0.3 \%$ (elbow extensors), $1.5 \%$ (knee flexors) and 2.7\% (knee extensors). The same trained researcher performed all ultrasound measurements. Muscle thickness measurements for the upper- and lower- body have been validated by magnetic resonance imaging (MRI) and have been identified as a significant predictor of elbow flexor and extensor and knee extensor volume ( $r=0.91-0.96$; Miyatani et al., 2002; 2000).

6.5.2 Muscle strength. Muscle strength was assessed using a 1-repetition maximum (1-RM) standard testing procedure in the Aging Muscle and Bone Health Laboratory, University of Regina. At least 72 hours following the last familiarization training session, 1-RM strength testing for the leg press, chest press, and elbow and knee flexion and extension (Pulse Exercise Systems Inc., Winnipeg, Canada) was performed to determine baseline 1-RM. All measurements were performed by the same researcher, blinded to supplementation groups. Following 10-minutes of cycling on a stationary cycle ergometer (Ergomedic 828 E, Monark, GIH Sweden) at a self-selected intensity, participants performed two warm-up sets in order: 1 set of 10 repetitions using a weight determined by each participant to be comfortable and 1 set of 5 repetitions using increased weight. Two-minutes following the warm-up sets, weight was progressively increased for each subsequent 1-RM attempt with a 2-minute rest interval.

To measure the 1-RM leg press, a bilateral leg press machine was used. Following a demonstration, participants were positioned in the leg press so that a $90^{\circ}$ angle at the knee was achieved and feet placed shoulder width apart. Participants were instructed to 
push the weight away from their body to full extension without locking the knees before returning to the starting position. This protocol was repeated until their 1-RM was achieved.

For 1-RM chest press, participant's were positioned in a bilateral, chest press machine with both feet flat on the floor. Following a demonstration, participants gripped the bars with a pronated grip, approximately shoulder width apart, and pushed the weight away from their body until full extension was achieved. Participants were instructed not to lift their buttocks off the bench or arch their back during the lift. This protocol was repeated until their 1-RM was achieved.

For 1-RM knee extension, participants were positioned in a bilateral, seated knee extension machine so that the knees were aligned with the axis of the machine and the lower part of the legs touched the padded lever arm. Following a demonstration, participants were instructed to grasp the handles on either side of the seat, keep their back firmly against the back pad and to not lift their buttocks off the seat during the lift. Participants were instructed to keep their feet parallel to each other and extend their legs until full extension was achieved. This protocol was repeated until their 1-RM was achieved.

For 1-RM knee flexion, participants were positioned in a bilateral, seated leg curl machine so that the knees were aligned with the axis of the leg curl machine and the back of the lower part of the leg, below the gastrocnemius but above the Achilles tendon, touched the padded lever arm. Following a demonstration, participants were instructed to grasp the handles and lift the weight to the point where a $90^{\circ}$ angle at the knee was achieved. Participants were instructed to keep their back firmly against the back pad and to not lift their buttocks off the seat during the lift. This protocol was repeated until their 
1-RM was achieved.

For 1-RM elbow extension, participants were positioned in a bilateral, seated elbow extension machine with both feet on the floor. Following a demonstration, participants were instructed to push the weight away from their body until full extension of the elbow was achieved, using a neutral grip. Participants were instructed not to lift their buttocks off the seat and to keep their back against the back pad during the lift. This protocol was repeated until their 1-RM was achieved.

For 1-RM elbow flexion, participants were positioned in a bilateral, seated biceps curl machine with both feet on the floor. Following a demonstration, participants were instructed to curl the weight towards their body so that a $90^{\circ}$ angle at the elbow was achieved. Participants were instructed not to lift their buttocks off the seat during the lift. This protocol was repeated until their 1-RM was achieved.

6.5.3 Peak Torque. Peak torque $(\mathrm{Nm})$ was measured for the knee flexors and extensors at angular velocities of $1.05 \mathrm{rad} / \mathrm{s}$ and $3.14 \mathrm{rad} / \mathrm{s}$ using an isokinetic dynamometer (CSMI Humac Norm, Computer Sports Medicine, USA). All torque measurements were performed on the right leg. Participants were seated and positioned at a back angle of $85^{\circ}$ with a stabilizing harness fastened against their chest to stabilize the upper body. A stabilizing belt was also secured across the participants left leg. The dynamometer was set to concentric mode. Knee flexion and extension peak torque was measured at each speed through a $90^{\circ}-170^{\circ}$ range of motion. Torque measures were corrected against gravity on the lever arm of the dynamometer and for each participant's right leg. The rotational axis of the dynamometer was positioned to be coxial with the knee axis (lateral femoral condyle) during the test (Candow et al., 2001). Participant's 
were familiarized with the dynamometer and the testing protocol by performing five repetitions of knee flexion and extension at each velocity $(1.05 \mathrm{rad} / \mathrm{s}$ and $3.14 \mathrm{rad} / \mathrm{s})$ prior to baseline assessment. One repetition of knee extension at maximal effort immediately followed by knee flexion was performed three times at each velocity. The dynamometer was set to 1-minute rest intervals between repetitions as well as between sets. The highest torque value during the three repetitions at each velocity $(1.05 \mathrm{rad} / \mathrm{s}$ and $3.14 \mathrm{rad} / \mathrm{s})$ was used for analysis. The same researcher performed all assessments. The coefficients of variation from previous research for the knee flexors were 5.4\% (1.05 rad/s) and 2.1\% (3.14 $\mathrm{rad} / \mathrm{s})$ and $4.3 \%(1.05 \mathrm{rad} / \mathrm{s})$ and $2.3 \%(3.14 \mathrm{rad} / \mathrm{s})$ for the knee extensors (Candow \& Chilibeck, 2005).

6.5.4 Functionality tests. Dynamic balance was measured by having participants walk backwards tandem (i.e. toe to heel) over a distance of $6 \mathrm{~m}$ on a $10 \mathrm{~cm}$ wide board that was raised $4 \mathrm{~cm}$ off the ground. The number of errors (i.e. number of times the participant stepped off the walking board) during the test, as well as the time it took to walk the length of the board, was recorded. Each participant performed two trials and were instructed to complete the task as quickly as possible. The average time-tocompletion and number of falls across the two trials was used for the assessment of dynamic balance.

Walking speed (sec) was assessed by the time required to walk an $80 \mathrm{~m}$ course. Participants were instructed to walk the course as fast as possible while keeping one foot in contact with the ground at all times. The same researcher performed all tests of functionality. 
6.5.5 Diet. Dietary intake was recorded prior to and during the final week of supplementation and HVRT to assess differences in total energy (kcal) and macronutrient composition between groups. Participants used a 3-day food record (Appendix F) to record their intake for two weekdays and one weekend day. Participants were instructed to record all food and drink items, along with details relating to portion sizes for the three designated days. MyFitnessPal (http://www.myfitnesspal.com) was used to analyze average kcal, carbohydrate, fat and protein consumption.

6.5.6 Adverse Event Assessment. In the case of an adverse event, participants were required to complete an adverse event form (Appendix G) in order to describe details on the type and of severity of the event (i.e. mild, moderate, severe, or life threatening), the frequency, and the relationship to the study (i.e. not related, unlikely, possible, probable, or definite).

\subsection{Statistical Analyses}

A 2 (group: creatine vs. placebo) x 2 (time: pre- vs. post-training) repeated measures analysis of variance (ANOVA) was performed to determine differences between groups over time for the dependent variables of muscle thickness, muscle strength, relative strength $(\mathrm{kg} / \mathrm{cm})$, peak torque, relative peak torque $(\mathrm{Nm} / \mathrm{cm})$, tasks of functionality, and diet. If significant interactions were detected, a one-factor ANOVA on absolute change scores $(\Delta=$ post mean - pre mean $)$ was performed to confirm the interaction. A one-factor ANOVA was also used to assess baseline data, training volume, and absolute change scores. ANCOVA was used to analyze differences in balance board time to completion and dietary fat intake with baseline values being used as a covariate as 
they were significantly different between groups. Significance was set at an alpha level of $p<0.05$. The magnitude of the difference between significant means was determined by partial eta squared $\left(\eta^{2}\right)$. Statistical analyses were performed using IBM $®$ SPSS $®$ Statistics, v. 24.

\section{Results}

\subsection{Participants}

Twenty-seven participants were randomized into the study (see Figure 1 for a summary of recruitment, allocation and analysis). However, one participant had to withdraw during the familiarization phase due to knee pain prior to randomization. Therefore, twenty-six participants started the supplementation and resistance training portion of the study. Two participants (one from each group) then withdrew due to time constraints unrelated to the study. One adverse event was reported during the study (patellofemoral sprain), resulting in the participant (placebo group) to voluntarily withdraw. Twenty-four participants $(\mathrm{CR}=12, \mathrm{PLA}=12)$ completed the study. Twentyone participants $(\mathrm{CR}=10, \mathrm{PLA}=11)$ were able to provide 3 -day food records.

Following the intervention, a retrospective supplementation identification questionnaire was administered to each participant. Nine of the twelve participants in the CR group correctly guessed they were receiving creatine and three participants incorrectly guessed. In the PLA group, six participants correctly guessed they were receiving placebo while six participants incorrectly guessed. Training compliance was similar between groups over time (CR: 188/192 sessions completed or 98\%; PLA: $182 / 192$ or $95 \%$ ). Supplementation compliance, based on participants entries in their logs, was similar between groups over time (CR: 660/672 days or 98\%; PLA: 668/672 days or $99 \%$ ). 


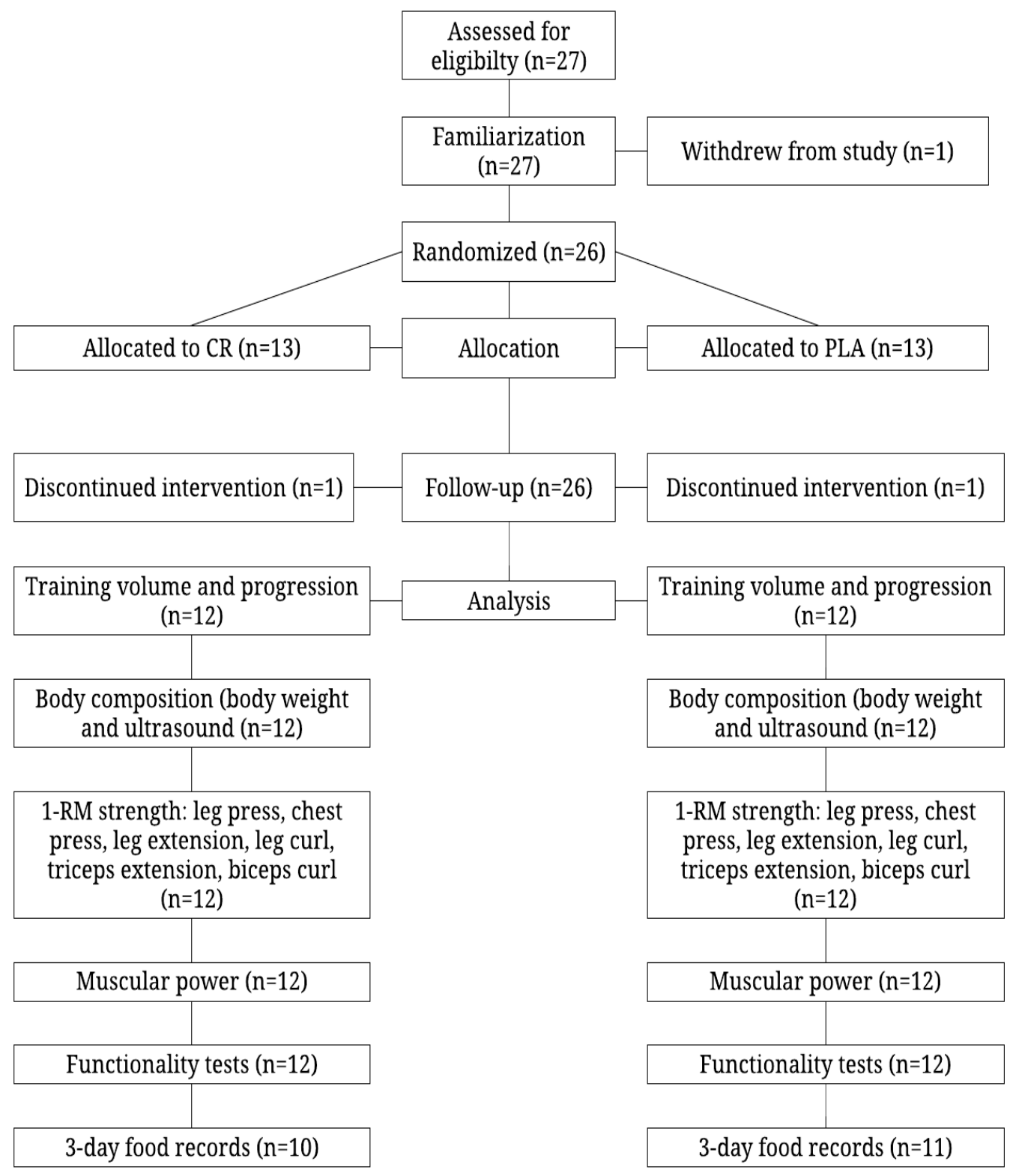

Figure 1. Summary of recruitment, allocation and analyses. 
Baseline data are presented in Table 1. There were no significant differences between groups for any baseline measurement except balance board completion time and dietary fat intake. The creatine group took longer to complete the balance board test compared to the placebo group $(\mathrm{F}[1,37]=6.22, \mathrm{p}=0.021)$. Furthermore, the creatine group consumed less fat than the placebo group $(\mathrm{F}[1,19]=4.91, \mathrm{p}=0.039)$. Both groups increased body mass equally over the eight weeks of training and supplementation $\left(\mathrm{F}[1,22]=14.43, \mathrm{p}=0.001, \eta^{2}=0.396 ; \mathrm{CR}: 1.80 \mathrm{~kg}[0.73,2.86] ;\right.$ PLA: $0.96 \mathrm{~kg}[-0.22$, 2.16]). 
Table 1. Baseline data

\begin{tabular}{|c|c|c|c|}
\hline & Placebo & Creatine & p-value \\
\hline Age (yrs) & $58.16(5.85)$ & $59.00(7.07)$ & 0.756 \\
\hline Mass (kg) & $92.08(23.30)$ & $94.84(14.37)$ & 0.730 \\
\hline Height $(\mathrm{cm})$ & $175.91(8.21)$ & $176.41(8.62)$ & 0.886 \\
\hline \multicolumn{4}{|l|}{$\begin{array}{l}\text { Physical activity score (arbitrary } \\
\text { units) }\end{array}$} \\
\hline \multicolumn{4}{|l|}{ Muscle Thickness (cm) } \\
\hline Elbow flexors & $3.96(0.36)$ & $4.07(0.41)$ & 0.492 \\
\hline Elbow extensors & $4.69(1.03)$ & $5.04(0.61)$ & 0.325 \\
\hline Knee extensors & $4.65(0.94)$ & $4.84(0.66)$ & 0.580 \\
\hline Knee flexors & $6.04(0.28)$ & $5.97(0.82)$ & 0.789 \\
\hline $\begin{array}{l}\text { Upper body (Elbow flexors and } \\
\text { extensors) }\end{array}$ & $8.65(1.23)$ & $9.11(0.74)$ & 0.281 \\
\hline $\begin{array}{l}\text { Lower body (Knee flexors and } \\
\text { extensors) }\end{array}$ & $10.70(1.00)$ & $10.82(1.40)$ & 0.814 \\
\hline $\begin{array}{l}\text { Total body (All muscle groups } \\
\text { combined) }\end{array}$ & $19.35(1.94)$ & $19.93(2.00)$ & 0.480 \\
\hline \multicolumn{4}{|l|}{ Strength (kg) } \\
\hline Chest Press & $76.66(12.60)$ & $78.66(16.81)$ & 0.745 \\
\hline Leg Press & $240.50(105.76)$ & $265.00(81.00)$ & 0.531 \\
\hline Elbow flexion & $52.91(10.49)$ & $51.91(12.94)$ & 0.837 \\
\hline Elbow extension & $48.58(9.14)$ & $49.91(13.73)$ & 0.782 \\
\hline Knee extension & $118.16(19.00)$ & $119.50(22.67)$ & 0.877 \\
\hline Knee flexion & $83.91(13.62)$ & $92.41(22.00)$ & 0.267 \\
\hline $\begin{array}{l}\text { Upper body (Chest press, elbow } \\
\text { flexors and extensors) }\end{array}$ & $178.16(28.66)$ & $180.50(42.19)$ & 0.876 \\
\hline $\begin{array}{l}\text { Lower body (Leg Press, knee } \\
\text { flexors and extensors }\end{array}$ & $442.58(120.45)$ & $476.91(116.98)$ & 0.486 \\
\hline $\begin{array}{l}\text { Total body (All muscle groups } \\
\text { combined) }\end{array}$ & $620.75(144.77)$ & $657.41(150.33)$ & 0.549 \\
\hline \multicolumn{4}{|l|}{ Relative Strength $(\mathrm{kg} / \mathrm{cm})$} \\
\hline Elbow flexion & $13.31(1.99)$ & $12.68(2.60)$ & 0.513 \\
\hline Elbow extension & $10.64(2.30)$ & $10.07(3.11)$ & 0.614 \\
\hline Knee extension & $25.98(4.70)$ & $25.09(5.94)$ & 0.689 \\
\hline Knee flexion & $13.89(2.29)$ & $15.55(3.26)$ & 0.164 \\
\hline $\begin{array}{l}\text { Upper body (Elbow flexion and } \\
\text { extension) }\end{array}$ & $23.96(3.54)$ & $22.76(5.34)$ & 0.523 \\
\hline $\begin{array}{l}\text { Lower body (Knee flexion and } \\
\text { extension) }\end{array}$ & $42.85(5.63)$ & $44.80(9.13)$ & 0.537 \\
\hline $\begin{array}{l}\text { Total body (All muscle groups } \\
\text { combined) }\end{array}$ & $63.84(7.07)$ & $63.41(12.62)$ & 0.919 \\
\hline Torque $(\mathrm{Nm})$ & & & \\
\hline
\end{tabular}


EFFECTS OF HIGH-VELOCITY RESISTANCE TRAINING AND CREATINE 30 SUPPLEMENTATION IN UNTRAINED HEALTHY AGING MALE

\begin{tabular}{|l|c|c|c|}
\hline Knee extension $(1.05 \mathrm{rad} / \mathrm{s})$ & $188.35(40.7)$ & $182.17(54.19)$ & 0.755 \\
\hline Knee flexion $(1.05 \mathrm{rad} / \mathrm{s})$ & $104.77(17.50)$ & $114.98(26.68)$ & 0.280 \\
\hline Knee extension $(3.14 \mathrm{rad} / \mathrm{s})$ & $113.52(26.45)$ & $118.51(42.01)$ & 0.731 \\
\hline Knee flexion $(3.14 \mathrm{rad} / \mathrm{s})$ & $84.33(25.49)$ & $88.28(24.54)$ & 0.703 \\
\hline $\begin{array}{l}\text { Knee flexion and extension }(1.05 \\
\mathrm{rad} / \mathrm{s})\end{array}$ & $293.12(56.64)$ & $297.16(79.38)$ & 0.887 \\
\hline $\begin{array}{l}\text { Knee flexion and extension }(3.14 \\
\mathrm{rad} / \mathrm{s})\end{array}$ & $197.86(46.89)$ & $206.79(64.56)$ & 0.702 \\
\hline Relative Torque $(\mathrm{Nm} / \mathrm{cm})$ & & & \\
\hline Knee extension $(1.05 \mathrm{rad} / \mathrm{s})$ & $42.24(13.70)$ & $37.73(10.75)$ & 0.380 \\
\hline Knee flexion $(1.05 \mathrm{rad} / \mathrm{s})$ & $17.33(2.85)$ & $19.23(3.39)$ & 0.150 \\
\hline Knee extension $(3.14 \mathrm{rad} / \mathrm{s})$ & $25.65(8.83)$ & $24.23(8.45)$ & 0.692 \\
\hline Knee flexion $(3.14 \mathrm{rad} / \mathrm{s})$ & $13.93(4.21)$ & $14.72(3.29)$ & 0.617 \\
\hline Tasks of Functionality & & & \\
\hline Walking time $(\mathrm{s})$ & $19.14(2.41)$ & $20.25(3.21)$ & 0.350 \\
\hline Balance board time $(\mathrm{s})$ & $16.63(4.06)$ & $23.05(7.94)$ & $0.021 *$ \\
\hline Number of falls & $2.66(2.53)$ & $3.83(3.56)$ & 0.365 \\
\hline Diet & & & \\
\hline Energy intake $(\mathrm{kcal} / \mathrm{day})$ & $2272.03(557.29)$ & $1991.36(311.48)$ & 0.165 \\
\hline Carbohydrate $(\mathrm{g} /$ day) & $252.96(84.03)$ & $240.84(60.32)$ & 0.706 \\
\hline Fat (g/day) & $92.06(26.80)$ & $72.36(11.82)$ & $0.039^{*}$ \\
\hline Protein $(\mathrm{g} /$ day) & $98.76(31.71)$ & $94.84(24.18)$ & 0.752 \\
\hline Relative protein $(\mathrm{g} / \mathrm{kg})$ & $1.16(0.53)$ & $1.01(0.19)$ & 0.376 \\
\hline
\end{tabular}

Values are means (standard deviation). * Significant difference at baseline 


\subsection{Muscle Thickness}

There was a significant increase over time (Table 2 ) for the elbow flexors (F [1, $\left.22]=97.52, \mathrm{p}<0.001, \eta^{2}=0.81\right)$, elbow extensors $\left(F[1,32]=108.78, \mathrm{p}<0.001, \eta^{2}=\right.$ $0.83)$, elbow flexors and extensors combined $\left(F[1,32]=143.81, \mathrm{p}<0.001, \eta^{2}=0.86\right)$, knee extensors $\left(F[1,22]=67.44, p<0.001, \eta^{2}=0.75\right)$, knee flexors $(F[1,22]=23.87, p$ $\left.<0.001, \eta^{2}=0.52\right)$, knee flexors and extensors combined $\left(F[1,22]=83.97, p<0.001, \eta^{2}\right.$ $=0.79)$, and all muscle groups combined $\left(F[1,22]=260.68, p<0.001, \eta^{2}=0.92\right)$, with no significant differences between groups. 
UNTRAINED HEALTHY AGING MALE

Table 2. Mean Absolute Changes (95\% CI) From Baseline to 8 weeks for Muscle Thickness (cm)

\begin{tabular}{|c|c|c|c|c|c|}
\hline & Placebo & Creatine & $\begin{array}{c}\text { Exercise } \\
\text { p-value }\end{array}$ & $\begin{array}{c}\text { Supplement } \\
\text { p-value }\end{array}$ & $\begin{array}{c}\text { Interaction } \\
\text { p-value }\end{array}$ \\
\hline Elbow flexors & $0.25(0.16,0.33)$ & $0.28(0.19,0.37)$ & $<0.001^{*}$ & 0.442 & 0.498 \\
\hline Elbow extensors & $0.35(0.24,0.46)$ & $0.29(0.21,0.38)$ & $<0.001^{*}$ & 0.378 & 0.369 \\
\hline Knee extensors & $0.42(0.28,0.56)$ & $0.42(0.24,0.60)$ & $<0.001^{*}$ & 0.589 & 0.987 \\
\hline Knee flexors & $0.16(0.04,0.28)$ & $0.19(0.09,0.30)$ & $<0.001^{*}$ & 0.843 & 0.650 \\
\hline Upper body & $0.60(0.45,0.75)$ & $0.58(0.42,0.74)$ & $<0.001^{*}$ & 0.313 & 0.842 \\
\hline Lower body & $0.58(0.41,0.76)$ & $0.62(0.39,0.85)$ & $<0.001^{*}$ & 0.795 & 0.789 \\
\hline Total body & $1.19(0.94,1.44)$ & $1.21(1.00,1.41)$ & $<0.001^{*}$ & 0.500 & 0.916 \\
\hline
\end{tabular}

* Time main effect $(\mathrm{p}<0.05)$

Upper body $=$ Elbow flexors and extensors

Lower body $=$ Knee flexors and extensors

Total body $=$ all muscle groups combined 


\subsection{Muscle Strength}

Both groups experienced a similar increase in strength (Table 3$)$ for chest press (F $\left.[1,22]=94.22, \mathrm{p}<0.001, \eta^{2}=0.81\right)$, elbow flexion $\left(\mathrm{F}[1,22]=107.75, \mathrm{p}<0.001, \eta^{2}=\right.$ $0.83)$, elbow extension $\left(F[1,22]=132.48, \mathrm{p}<0.001, \eta^{2}=0.85\right)$, upper-body muscle groups combined $\left(\mathrm{F}[1,22]=137.31, \mathrm{p}<0.001, \eta^{2}=0.86\right)$, knee extension $(\mathrm{F}[1,22]=$ $\left.160.40, \mathrm{p}<0.001, \eta^{2}=0.87\right)$, knee flexion $\left(\mathrm{F}[1,22]=83.88, \mathrm{p}<0.001, \eta^{2}=0.7927\right)$ and all muscle groups combined $\left(\mathrm{F}[1,22]=140.42, \mathrm{p}<0.001, \eta^{2}=0.86\right)$.

There was a group $\mathrm{x}$ time interaction for leg press strength $(\mathrm{p}<0.05)$. Both groups increased leg press strength over time $\left(F[1,22]=64.60, p<0.001, \eta^{2}=0.74\right)$, with greater gains observed in the creatine group $\left(F[1,22]=4.54, p=0.044, \eta^{2}=0.171\right.$; Creatine: pre $265.00 \pm 81.00 \mathrm{~kg}$, post $409.50 \pm 137.03 \mathrm{~kg}$; Placebo: pre $240.50 \pm 105.76$ $\mathrm{kg}$, post $324.41 \pm 133.99 \mathrm{~kg}$ ). Similar to leg press strength, there was a group $\mathrm{x}$ time interaction for total lower-body strength (leg press, knee flexion and extension combined; $\mathrm{p}<0.05)$. Both groups increased strength over time $\left(\mathrm{F}[1,22]=109.13, \mathrm{p}<0.001, \eta^{2}=\right.$ $0.83)$, with greater gains in the creatine group $\left(F[1,22]=4.89, p=0.039, \eta^{2}=0.18\right.$; Creatine: pre $476.91 \pm 116.98 \mathrm{~kg}$, post $681.66 \pm 179.15 \mathrm{~kg}$; Placebo: pre $442.58 \pm 120.45$ $\mathrm{kg}$, post $576.16 \pm 156.02 \mathrm{~kg}$ ). 
UNTRAINED HEALTHY AGING MALE

Table 3. Mean Absolute Changes (95\% CI) From Baseline to 8 weeks for Muscle Strength (kg)

\begin{tabular}{|c|c|c|c|c|c|}
\hline & Placebo & Creatine & $\begin{array}{c}\text { Exercise } \\
\text { p-value }\end{array}$ & $\begin{array}{c}\text { Supplement } \\
\text { p-value }\end{array}$ & $\begin{array}{c}\text { Interaction } \\
\text { p-value }\end{array}$ \\
\hline Chest Press & $17.58(13.62,21.54)$ & $19.00(11.71,26.28)$ & $<0.001^{*}$ & 0.715 & 0.711 \\
\hline Elbow flexion & $16.50(10.94,22.05)$ & $15.41(11.55,19.28)$ & $<0.001^{*}$ & 0.786 & 0.728 \\
\hline Elbow extension & $13.66(11.36,15.97)$ & $13.75(9.04,18.45)$ & $<0.001^{*}$ & 0.806 & 0.972 \\
\hline Leg Press & $83.91(53.00,114.82)$ & $144.50(90.12,198.87)$ & $<0.001^{*}$ & 0.241 & $0.044^{* *}$ \\
\hline Knee extension & $28.86(20.72,36.60)$ & $30.91(24.26,37.56)$ & $<0.001^{*}$ & 0.782 & 0.637 \\
\hline Knee flexion & $21.00(13.45,28.54)$ & $29.33(19.88,38.78)$ & $<0.001^{*}$ & 0.181 & 0.144 \\
\hline Upper body & $47.75(37.73,57.76)$ & $48.16(33.19,63.14)$ & $<0.001^{*}$ & 0.887 & 0.960 \\
\hline Lower body & $133.58(93.92,173.24)$ & $204.75(145.51,263.98)$ & $<0.001^{*}$ & 0.234 & $0.039^{* *}$ \\
\hline Total body & $181.33(133.05,229.60)$ & $252.91(188.30,317.53)$ & $<0.001^{*}$ & 0.322 & 0.064 \\
\hline
\end{tabular}

* Time main effect $(\mathrm{p}<0.05)$

** Creatine greater than placebo

Upper body $=$ Elbow flexion and extension

Lower body $=$ Knee flexion and extension

Total body $=$ all muscle groups combined 


\subsection{Relative Strength}

There was an increase over time $(\mathrm{p}<0.05$; Table 4$)$ for the elbow flexion $(\mathrm{F}[1$, $\left.22]=72.77, \mathrm{p}<0.001, \eta^{2}=0.76\right)$, elbow extension $\left(\mathrm{F}[1,22]=64.57, \mathrm{p}<0.001, \eta^{2}=\right.$ 0.74), elbow flexion and extension combined $\left(F[1,22]=101.00, p<0.001, \eta^{2}=0.82\right)$, knee extension $\left(F[1,22]=26.88, p<0.001, \eta^{2}=0.55\right)$, knee flexion $(F[1,22]=83.36, p$ $\left.<0.001, \eta^{2}=0.79\right)$, knee flexion and extension combined $\left(F[1,22]=26.88, p<0.001, \eta^{2}\right.$ $=0.55)$, and all muscle groups combined $\left(F[1,22]=116.50, p<0.001, \eta^{2}=0.84\right)$, with no significant differences between groups. 
UNTRAINED HEALTHY AGING MALE

Table 4. Mean Absolute Changes (95\% CI) From Baseline to 8 weeks for Relative Strength (kg/cm)

\begin{tabular}{|l|c|c|c|c|c|}
\hline & Placebo & Creatine & $\begin{array}{c}\text { Exercise } \\
\text { p-value }\end{array}$ & $\begin{array}{c}\text { Supplement } \\
\text { p-value }\end{array}$ & $\begin{array}{c}\text { Interaction } \\
\text { p-value }\end{array}$ \\
\hline Elbow flexion & $3.09(1.93,4.24)$ & $2.73(1.76,3.69)$ & $<0.001^{*}$ & 0.459 & 0.604 \\
\hline Elbow extension & $2.11(1.38,2.84)$ & $2.02(1.15,2.89)$ & $<0.001^{*}$ & 0.632 & 0.866 \\
\hline Knee extension & $3.65(1.22,6.08)$ & $4.00(1.84,6.15)$ & $<0.001^{*}$ & 0.755 & 0.816 \\
\hline Knee flexion & $2.97(1.82,4.12)$ & $4.14(2.87,5.42)$ & $<0.001^{*}$ & 0.100 & 0.147 \\
\hline Upper body & $5.20(3.87,6.52)$ & $4.75(3.02,6.48)$ & $<0.001^{*}$ & 0.510 & 0.657 \\
\hline Lower body & $3.65(1.22,6.08)$ & $4.00(1.84,6.15)$ & $<0.001^{*}$ & 0.511 & 0.816 \\
\hline Total body & $11.83(7.98,15.68)$ & $12.90(9.65,16.16)$ & $<0.001^{*}$ & 0.918 & 0.644 \\
\hline
\end{tabular}

* Time main effect $(\mathrm{p}<0.05)$

Upper body $=$ Elbow flexion and extension

Lower body $=$ Knee flexion and extension

Total body $=$ all muscle groups combined 


\subsection{Peak Torque}

There was a time main effect $(\mathrm{p}<0.05$; Table 5$)$ for knee flexion peak torque at $1.05 \mathrm{rad} / \mathrm{s}\left(\mathrm{F}[1,22]=14.84, \mathrm{p}<0.001, \eta^{2}=0.40\right)$ and $3.14 \mathrm{rad} / \mathrm{s}(\mathrm{F}[1,22]=14.81, \mathrm{p}<$ $\left.0.001, \eta^{2}=0.40\right)$ and for knee flexion and extension peak torque combined at $3.14 \mathrm{rad} / \mathrm{s}$ $\left(\mathrm{F}[1,22]=4.50, \mathrm{p}=0.045, \eta^{2}=0.17\right)$, with no significant differences between groups. Knee extension peak torque did not significantly change over time at either velocity (1.05 $\mathrm{rad} / \mathrm{s}: \mathrm{F}[1,22]=0.081, \mathrm{p}=0.779 ; 3.14 \mathrm{rad} / \mathrm{s}: \mathrm{F}[1,22]=0.150, \mathrm{p}=0.702)$. There was also no significant change in knee flexion and extension peak torque combined at 1.05 $\mathrm{rad} / \mathrm{s}(\mathrm{F}[1,22]=3.41, \mathrm{p}=0.078)$. 
UNTRAINED HEALTHY AGING MALE

Table 5. Mean Absolute Changes (95\% CI) From Baseline to 8 weeks for Torque (Nm)

\begin{tabular}{|l|c|c|c|c|c|}
\hline & Placebo & Creatine & $\begin{array}{c}\text { Exercise } \\
\text { p-value }\end{array}$ & $\begin{array}{c}\text { Supplement } \\
\text { p-value }\end{array}$ & $\begin{array}{c}\text { Interaction } \\
\text { p-value }\end{array}$ \\
\hline Knee extension $(1.05 \mathrm{rad} / \mathrm{s})$ & $0.97(-19.08,21.04$ & $2.04(-9.98,14.08)$ & 0.779 & 0.776 & 0.921 \\
\hline Knee flexion $(1.05 \mathrm{rad} / \mathrm{s})$ & $10.67(-2.23,23.59)$ & $14.73(8.10,21.35)$ & $<0.001^{*}$ & 0.260 & 0.545 \\
\hline Knee extension $(3.14 \mathrm{rad} / \mathrm{s})$ & $7.76(-10.45,25.98)$ & $-3.73(-17.60,10.10)$ & 0.702 & 0.957 & 0.281 \\
\hline Knee flexion $(3.14 \mathrm{rad} / \mathrm{s})$ & $10.33(-3.38,24.05)$ & $16.46(9.65,23.27)$ & $<0.001^{*}$ & 0.473 & 0.388 \\
\hline $\begin{array}{l}\text { Knee flexion and extension } \\
(1.05 \mathrm{rad} / \mathrm{s})\end{array}$ & $11.65(-19.30,42.61)$ & $16.77(3.06,30.49)$ & 0.078 & 0.825 & 0.742 \\
\hline $\begin{array}{l}\text { Knee flexion and extension } \\
(3.14 \mathrm{rad} / \mathrm{s})\end{array}$ & $18.10(-9.18,45.39$ & $12.73(-3.83,29.30)$ & $0.045^{*}$ & 0.786 & 0.715 \\
\hline
\end{tabular}

* Time main effect $(\mathrm{p}<0.05)$ 


\subsection{Relative Peak Torque}

There was a time main effect $(\mathrm{p}<0.05$; Table 6$)$ for knee extension $(1.05 \mathrm{rad} / \mathrm{s}: \mathrm{F}$ $\left.[1,22]=6.19, \mathrm{p}=0.021, \eta^{2}=0.22\right)$, knee flexion $(1.05 \mathrm{rad} / \mathrm{s}: \mathrm{F}[1,22]=9.73, \mathrm{p}=0.005$, $\left.\eta^{2}=0.30 ; 3.14 \mathrm{rad} / \mathrm{s}: \mathrm{F}[1,22]=8.73, \mathrm{p}=0.007, \eta^{2}=0.28\right)$, and knee flexion and extension peak torque combined $\left(3.14 \mathrm{rad} / \mathrm{s}: \mathrm{F}[1,22]=4.52, \mathrm{p}=0.045, \eta^{2}=0.17\right)$, with no significant differences between groups. There was no significant change over time for knee extension peak torque at $3.14 \mathrm{rad} / \mathrm{s}(\mathrm{F}[1,22]=3.39, \mathrm{p}=0.079)$ or knee flexion and extension peak torque combined at $1.05 \mathrm{rad} / \mathrm{s}(\mathrm{F}[1,22]=3.41, \mathrm{p}=0.078)$. 
UNTRAINED HEALTHY AGING MALE

Table 6. Mean Absolute Changes (95\% CI) From Baseline to 8 weeks for Relative Peak Torque $(\mathrm{Nm} / \mathrm{cm})$

\begin{tabular}{|l|c|c|c|c|c|}
\hline & Placebo & Creatine & $\begin{array}{c}\text { Exercise } \\
\text { p-value }\end{array}$ & $\begin{array}{c}\text { Supplement } \\
\text { p-value }\end{array}$ & $\begin{array}{c}\text { Interaction } \\
\text { p-value }\end{array}$ \\
\hline Knee extension $(1.05 \mathrm{rad} / \mathrm{s})$ & $-3.66(-8.25,0.92)$ & $-2.6(-5.71,0.51)$ & $0.021^{*}$ & 0.408 & 0.676 \\
\hline Knee flexion $(1.05 \mathrm{rad} / \mathrm{s})$ & $1.21(-0.57,3.00)$ & $1.88(0.63,3.14)$ & $0.005^{*}$ & 0.154 & 0.506 \\
\hline Knee extension $(3.14 \mathrm{rad} / \mathrm{s})$ & $-1.34(-4.88,2.18)$ & $-2.42(-5.20,0.36)$ & 0.079 & 0.544 & 0.606 \\
\hline Knee flexion $(3.14 \mathrm{rad} / \mathrm{s})$ & $1.28(-1.04,3.61)$ & $2.25(1.01,3.48)$ & $0.007^{*}$ & 0.360 & 0.429 \\
\hline $\begin{array}{l}\text { Knee flexion and extension } \\
(1.05 \mathrm{rad} / \mathrm{s})\end{array}$ & $11.65(-19.30,42.61)$ & $16.77(3.06,30.49)$ & 0.078 & 0.825 & 0.742 \\
\hline $\begin{array}{l}\text { Knee flexion and extension } \\
(3.14 \mathrm{rad} / \mathrm{s})\end{array}$ & $18.10(-9.18,45.39)$ & $12.73(-3.83,29.30)$ & $0.045^{*}$ & 0.786 & 0.715 \\
\hline
\end{tabular}

* Time main effect $(\mathrm{p}<0.05)$ 


\subsection{Functionality}

There was a time main effect $(\mathrm{p}<0.05$, Table 7$)$ for balance board time to completion $\left(\mathrm{F}[1,23]=6.630, \mathrm{p}=0.017 ; \eta^{2}=0.23\right)$, with no significant differences between groups. There were no significant changes over time for walking speed ( $\mathrm{F}$ [1, $22]=0.068, \mathrm{p}=0.797)$ or falls $(\mathrm{F}[1,23]=0.011, \mathrm{p}=0.916)$. 
UNTRAINED HEALTHY AGING MALE

Table 7. Mean Absolute Changes (95\% CI) From Baseline to 8 weeks for Tasks of Functionality

\begin{tabular}{|l|c|c|c|c|c|}
\hline & Placebo & Creatine & $\begin{array}{c}\text { Exercise } \\
\mathrm{p} \text {-value }\end{array}$ & $\begin{array}{c}\text { Supplement } \\
\mathrm{p} \text {-value }\end{array}$ & $\begin{array}{c}\text { Interaction } \\
\mathrm{p} \text {-value }\end{array}$ \\
\hline Walking speed (sec) & $-0.47(-1.14,0.19)$ & $0.36(-0.35,1.07)$ & 0.797 & 0.199 & 0.075 \\
\hline Balance board time (sec) & $-0.97(-3.61,1.66)$ & $-3.69(-6.69,-0.69)$ & $0.017^{*}$ & 0.678 & 0.230 \\
\hline Number of falls & $-0.09(-1.48,1.30)$ & $-0.08(-1.24,1.08)$ & 0.916 & 0.336 & 0.916 \\
\hline
\end{tabular}

* Time main effect $(\mathrm{p}<0.05)$ 


\subsection{Diet}

There was no significant change over time (Table 8 ) for total calories (kcal: F [1, $19]=0.043, \mathrm{p}=0.839)$, carbohydrate $(\mathrm{F}[1,19]=0.002, \mathrm{p}=0.961)$, fat $(\mathrm{F}[1,19]=$ $0.294, \mathrm{p}=0.594)$, protein $(\mathrm{F}[1,19]=0.185, \mathrm{p}=0.672)$ or relative protein $(\mathrm{g} / \mathrm{kg} ; \mathrm{F}[1$, $19]=0.938, p=0.345)$. 
UNTRAINED HEALTHY AGING MALE

Table 8. Mean Absolute Changes (95\% CI) From Baseline to 8 weeks for Total Calories (kcal/day),

Macronutrients (grams/day) and Relative Protein (g/kg body mass)

\begin{tabular}{|l|c|c|c|c|c|}
\hline & Placebo & Creatine & $\begin{array}{l}\text { Exercise } \\
\text { p-value }\end{array}$ & $\begin{array}{l}\text { Interaction } \\
\text { p-value }\end{array}$ & $\begin{array}{l}\text { Interaction } \\
\text { p-value }\end{array}$ \\
\hline Total calories & $-390.60(-1178.77,397.57)$ & $285.63(-532.48,1103.75)$ & 0.839 & 0.420 & 0.199 \\
\hline Carbohydrate & $-41.40(-192.01,109.21)$ & $45.27(-51.18,141.73)$ & 0.961 & 0.944 & 0.280 \\
\hline Fat & $-26.10(-64.01,11.81)$ & $11.63(-33.64,56.91)$ & 0.594 & 0.111 & 0.173 \\
\hline Protein & $-10.70(-70.07,48.67)$ & $-2.90(-44.03,38.21)$ & 0.672 & 0.783 & 0.808 \\
\hline Relative protein & $-0.09(-0.32,0.14)$ & $-0.02(-0.17,0.12)$ & 0.345 & 0.357 & 0.582 \\
\hline
\end{tabular}




\subsection{Training Volume}

There were no significant differences between groups in training volume for chest press $(\mathrm{F}[1,23]=0.052, \mathrm{p}=0.882 ; \mathrm{CR}: 35821.02 \pm 9456.75 \mathrm{~kg}$, PLA: $36691.28 \pm$ $9264.94 \mathrm{~kg})$, elbow flexion $(\mathrm{F}[1,23]=0.045, \mathrm{p}=0.883$; CR: $21968.93 \pm 6479.93 \mathrm{~kg}$, PLA: $21457.19 \pm 5215.51 \mathrm{~kg})$, elbow extension $(\mathrm{F}[1,23]=0.038, \mathrm{p}=0.847 ; \mathrm{CR}$ : $21059.84 \pm 6998.51 \mathrm{~kg}$, PLA: $21578.59 \pm 5970.92 \mathrm{~kg}$ ), upper-body muscle groups combined $(\mathrm{F}[1,23]=0.011, \mathrm{p}=0.917 ; \mathrm{CR}: 78849.81 \pm 21549.65 \mathrm{~kg}$, PLA: $79727.08 \pm$ $18968.50 \mathrm{~kg})$, leg press $(\mathrm{F}[1,23]=0.615, \mathrm{p}=0.441 ; \mathrm{CR}: 274480.11 \pm 99044.65 \mathrm{~kg}$, PLA: $244460.22 \pm 88105.59 \mathrm{~kg})$, knee extension $(\mathrm{F}[1,23]=0.624, \mathrm{p}=0.438 ; \mathrm{CR}$ : $62134.65 \pm 15350.41 \mathrm{~kg}$, PLA: $57306.25 \pm 14577.46 \mathrm{~kg})$, knee flexion $(\mathrm{F}[1,23]=0.532$ $\mathrm{p}=0.473 ; \mathrm{CR}: 62414.20 \pm 16726.98 \mathrm{~kg}$, PLA: $57381.81 \pm 17057.43 \mathrm{~kg})$, lower body muscle groups combined $(\mathrm{F}[1,23]=0.731, \mathrm{p}=0.917 ; \mathrm{CR}: 399028.97 \pm 120231.57 \mathrm{~kg}$, PLA: $359148.29 \pm 108007.09 \mathrm{~kg})$ or all muscle groups combined $(\mathrm{F}[1,23]=0.536, \mathrm{p}=$ 0.472; CR: $477878.91 \pm 136575.71 \mathrm{~kg}$, PLA: $438875.41 \pm 124236.33 \mathrm{~kg})$. 


\section{Discussion}

This was first study to examine the effects of HVRT and creatine supplementation in untrained healthy aging males. The main findings were: (1) Creatine supplementation produced greater gains in leg press and total lower-body strength, and (2) HVRT is a safe and effective intervention for improving muscle thickness, strength, relative strength and some measures of peak torque and functionality. From a healthy aging and knowledge translational perspective, these results are important as the reduction in muscle mass and strength with aging decreases the ability to perform activities of daily living (Manini \& Clark, 2013) and improvements in muscle size may lead to greater functionality over time (Chalé et al., 2013). Furthermore, increasing lower-body muscle strength is clinically significant as lower-body muscle groups have greater strength deficits compared to upper-body muscle groups in aging adults (Candow and Chilibeck, 2005).

The greater increase in leg press strength from creatine is in agreement with two recent meta-analyses on creatine supplementation and resistance training in aging adults. In the most comprehensive analysis, Chilibeck et al., (2017) examined the effects of creatine supplementation and placebo during resistance training (7-52 weeks) in 721 aging adults (57-70 years of age) across 22 eligible studies. Results showed that creatine during resistance training increased leg press strength (standardized mean difference: $0.24,95 \% \mathrm{CI}[0.05,0.43], \mathrm{p}=0.01)$ more than placebo and resistance training.

Previously, Devries \& Phillips (2014) analyzed over 300 men and women (55-71 years of age) who consumed creatine (3-25 grams) during resistance training (7-26 weeks) across 10 eligible studies. Compared to placebo, creatine significantly increased leg press strength (weighted mean difference: $3.25 \mathrm{~kg}, 95 \% \mathrm{CI}[0.47,6.03], \mathrm{p}=0.02$ ). While the 
mechanisms explaining the greater increase in leg press strength from creatine remain to be elucidated, there is evidence that high-energy phosphate metabolism may be involved (McCully and Posner, 1992). Aging adults have reduced intramuscular PCr stores in the vastus lateralis (i.e. knee extensors; Chilibeck et al., 2017) which may have precipitated a greater response from creatine supplementation during activation of these muscle groups (i.e. leg press, knee extension). There is evidence that creatine supplementation increases intramuscular $\mathrm{PCr}$ and subsequently muscle performance in aging adults [for reviews see Candow et al., 2014; Chilibeck et al., 2017]. Therefore, it is possible that aging males who supplemented with creatine experienced greater PCr resynthesis during resistance training and over time, this contributed to the greater gains in strength. However, since no measure of high-energy phosphate metabolism was made in the present study, this theory is speculative. In addition to high-energy phosphate metabolism, creatine may have also influenced muscle protein kinetics (satellite cells, myogenic transcription factors, protein kinases involved in the mTOR signalling pathway, anabolic hormone regulation) and inflammatory processes which could have contributed to the significant gains in lower-body strength (for reviews see for reviews see Candow et al., 2014; Chilibeck, et al., 2017; Gualano et al., 2016; Kreider et al., 2017). Alternatively, differences in the amount of work (i.e. training volume) performed may also help explain the differences in leg press and total lower-body strength. Although not statistically significant, the creatine group performed more work over time for the leg press (CR: $274480.11 \pm 99044.65 \mathrm{~kg}$, PLA: $244460.22 \pm 88105.59 \mathrm{~kg})$, knee flexion (CR: 62414.20 $\pm 16726.98 \mathrm{~kg}$, PLA: $57381.81 \pm 17057.43 \mathrm{~kg})$ and knee extension exercises (CR: $62134.65 \pm 15350.41 \mathrm{~kg}$, PLA: $57306.25 \pm 14577.46 \mathrm{~kg})$. 


\section{SUPPLEMENTATION IN UNTRAINED HEALTHY AGING MALE}

It is unclear why creatine did not have a greater effect on upper-body muscle strength compared to placebo. However, the design of the resistance training program may have influenced the results. For example, only three sets per exercise were performed for upper-body muscle groups compared to four sets for lower-body muscle groups. Rationale for this design difference was based on previous findings that lowerbody muscle groups exhibit a greater strength deficit (Candow and Chilibeck, 2005) and an attenuated muscle hypertrophic response to resistance training compared to upperbody muscle groups (Weisgarber et al., 2015). In addition, there is evidence that aging adults do not respond as well to the chest press exercise compared to the leg press exercise (Brown et al., 1990). Furthermore, in contrast to lower-body training volume, the amount of work performed for the chest press (CR: $35821.02 \pm 9456.75 \mathrm{~kg}$, PLA: $36691.28 \pm 9264.94 \mathrm{~kg}$ ), elbow flexion (CR: $21968.93 \pm 6479.93 \mathrm{~kg}$, PLA: $21457.19 \pm$ $5215.51 \mathrm{~kg})$ and elbow extension (CR: $21059.84 \pm 6998.51 \mathrm{~kg}$, PLA: $21578.59 \pm$ $5970.92 \mathrm{~kg}$ ) were very similar between groups, indicating that creatine supplementation had relatively no effect on upper-body muscle performance.

Creatine had no greater effect on regional muscle hypertrophy (thickness) compared to placebo. The lack of effect from creatine may be related to methodological issues. For example, three previous meta-analyses showed that creatine supplementation during resistance training increased whole-body lean tissue mass, as assessed by dualenergy X-ray absorptiometry, air-displacement plethysmography, or hydrostatic weighing, in aging adults compared to placebo (Candow et al., 2014; Chilibeck et al., 2017; Devries and Phillips, 2014). In the present study, ultrasonography was used to measure changes in muscle thickness over time. However, ultrasonography does not differentiate between contractile and non-contractile tissue (i.e. connective tissue, 
intramuscular fat) which may have influenced the lack of findings from creatine.

Furthermore, 3-day food records showed that males in the creatine group were only consuming $\sim 1.0 \mathrm{~g} / \mathrm{kg}$ of protein/day. Several reviews suggest that aging adults require $\geq$ $1.2 \mathrm{~g} / \mathrm{kg}$ of protein/day to maintain/increase muscle mass (Morton et al., 2018; Phillips et al., 2016; Traylor et al., 2018). Therefore, it is possible that the sub-optimal daily protein intake attenuated the muscle hypertrophic response to creatine over time. In addition, the short-duration of training may have jeopardized the ability to detect significant effects from creatine on muscle thickness. For example, in the Chilibeck et al. (2017) metaanalysis, all studies that showed a positive effect from creatine on muscle accretion were $\geq 10$ weeks in duration. Perhaps a longer training period ( $>8$ weeks) was needed to produce significant effects from creatine on muscle growth in aging adults.

HVRT was a safe and effective intervention for improving muscle hypertrophy, strength, relative strength and some measures of peak torque and functionality. These findings support previous research showing a beneficial effect from HVRT on muscle performance. For example, Häkkinen et al. (2001) observed a significant increase in mean fiber area of type I, type II, and type IIa in aging females $(67 \pm 3 ; n=10)$ and muscle strength in aging males and females following 6 months of HVRT. Furthermore, Bottaro et al. (2007) observed significant increases in leg press and chest press strength (27.12\% and $28.23 \%$, respectively) following 10 -weeks of HVRT in aging males (60-79 years old). Caserotti et al. (2008) also showed that HVRT was very effective for increasing maximal knee extension muscle strength and power in aging adults. Results across studies suggest that HVRT is an effective intervention for improving muscle accretion and muscle performance in aging adults. While the mechanistic actions explaining the positive effects of HVRT remain to be elucidated, muscle fiber 
recruitment patterns may be involved. Hennemann's 'size principle' of neuromuscular adaptation to resistance training indicates a hierarchy of muscle fiber recruitment, with Type I fibers being recruited first followed by Type IIa and then Type IIx (Henneman, 1957). Type II muscle fibers contribute to strength and muscle hypertrophy to a much greater degree than Type I fibers (Thorstensson, Hultén, Döbeln, \& Karlsson,1976). Speculation exists that the HVRT may preferentially recruit Type II muscle fibers leading to significant gains in muscle hypertrophy and muscle performance over time.

Unfortunately, muscle biopsies and electromyography were not performed in the present study, so consensus cannot be made.

There were several additional limitations to the study not previously mentioned. First, to achieve $80 \%$ statistical power, 34 participants were required. Unfortunately, 24 completed the study. This reduction in statistical power could have resulted in error. Second, it was assumed that all participants would respond to creatine supplementation. Research suggests that a main determinant of any response from creatine supplementation is initial muscle creatine concentration which is quite variable (Syrotuik and Bell, 2004). When replicating this experiment, it would be necessary to measure initial muscle creatine concentration using magnetic resonance spectroscopy or muscle biopsies to determine individual variation in muscle creatine accumulation in aging adults. Third, without controlling for diet, high red meat and seafood intake may have saturated muscles with creatine thereby influencing the effect of creatine supplementation. Fourth, results are specific to healthy, untrained, aging males. Finally, no measure of muscle fiber type composition, muscle cross-sectional area, myogenic transcription factors, muscle protein kinetics, or inflammatory properties were measured. Future research should assess the mechanistic actions of creatine and HVRT to better 
understand its effect on aging muscle biology.

The present study demonstrated that HVRT increased muscle thickness, strength, relative strength, and some measures of peak torque and functionality healthy untrained aging males. The addition of creatine supplementation to HVRT further augmented legpress strength and total lower body strength. These findings may have application for the design of effective lifestyle (i.e. resistance training, creatine) interventions which have a positive effect on aging muscle. 


\section{References}

Aagaard, P., Suetta, C., Caserotti, P., Magnusson, S. P., \& Kjær, M. (2010). Role of the nervous system in sarcopenia and muscle atrophy with aging: Strength training as a countermeasure. Scandinavian Journal of Medicine \& Science in Sports, 20(1), 49-64. http://dx.doi.org/10.1111/j.1600-0838.2009.01084.x

Abe, T., Fukashiro, S., Harada, Y., \& Kawamoto, K. (2001). Relationship between sprint performance and muscle fascicle length in female sprinters. Journal of Physiological Anthropology and Applied Human Science, 20(2), 141-147. http://doi.org/10.2114/jpa.20.141

Allen, R. E., \& Boxhorn, L. K. (1989). Regulation of skeletal muscle satellite cell proliferation and differentiation by transforming growth factor-beta, insulin-like growth factor I, and fibroblast growth factor. Journal of Cellular Physiology, 138(2), 311-315. http://dx.doi.org/10.1002/jcp.1041380213

Balagopal, P., Schimke, J. C., Ades, P., Adey, D., \& Nair, K. S. (2001). Age effect on transcript levels and synthesis rate of muscle $\mathrm{MHC}$ and response to resistance exercise. American Journal of Physiology-Endocrinology and Metabolism, 280(2), E203-E208.

Bales, C. W., \& Ritchie, C. S. (2002). Sarcopenia, weight loss, and nutritional frailty in the elderly. Annual Review of Nutrition, 22(1), 309-323. http://dx.doi.org/10.1146/annurev.nutr.22.010402.102715

Barcelos, R. P., Stefanello, S. T., Mauriz, J. L., Gonzalez-Gallego, J., \& Soares, F. A. A. (2016). Creatine and the liver: metabolism and possible interactions. Mini 
Reviews in Medicinal Chemistry, 16(1), 12-18.

http://dx.doi.org/10.2174/1389557515666150722102613

Barton-Davis, E. R., Shoturma, D. I., \& Sweeney, H. L. (1999). Contribution of satellite cells to IGF-I induced hypertrophy of skeletal muscle. Acta Physiologica Scandinavica, 167(4), 301-305. http://dx.doi.org/10.1046/j.1365$\underline{201 x .1999 .00618 . x}$

Bassey, E. J., Fiatarone, M. A., O'neill, E. F., Kelly, M., Evans, W. J., \& Lipsitz, L. A. (1992). Leg extensor power and functional performance in very old men and women. Clinical Science, 82(3), 321-327. http://dx.doi.org/10.1042/cs0820321

Baumgartner, R. N., Waters, D. L., Gallagher, D., Morley, J. E., \& Garry, P. J. (1999). Predictors of skeletal muscle mass in elderly men and women. Mechanisms of Ageing and Development, 107(2), 123-136. http://doi.org/10.1016/S0047$\underline{6374(98) 00130-4}$

Bautmans, I., \& Mets, T. (2005). A fatigue resistance test for elderly persons based on grip strength: reliability and comparison with healthy young subjects. Aging Clinical and Experimental Research, 17(3), 217-222.

http://dx.doi.org/10.1007/BF03324600

Bean, J. F., Herman, S., Kiely, D. K., Frey, I. C., Leveille, S. G., Fielding, R. A., \& Frontera, W. R. (2004). Increased Velocity Exercise Specific to Task (InVEST) training: a pilot study exploring effects on leg power, balance, and mobility in community-dwelling older women. Journal of the American Geriatrics Society, 799-804. http://dx.doi.org/10.1111/j.1532-5415.2004.52222.x

Bean, J. F., Kiely, D. K., Herman, S., Leveille, S. G., Mizer, K., Frontera, W. R., \& Fielding, R. A. (2002). The relationship between leg power and physical 
EFFECTS OF HIGH-VELOCITY RESISTANCE TRAINING AND CREATINE

SUPPLEMENTATION IN UNTRAINED HEALTHY AGING MALE

performance in mobility-limited older people. Journal of the American Geriatrics

Society, 50(3), 461-467. http://dx.doi.org/10.1046/j.1532-5415.2002.50111.x

Beaudart, C., Rizzoli, R., Bruyère, O., Reginster, J. Y., \& Biver, E. (2014). Sarcopenia:

burden and challenges for public health. Archives of Public Health, 72(1), 45.

https://doi.org/10.1186/2049-3258-72-45

Boonyarom, O., \& Inui, K. (2006). Atrophy and hypertrophy of skeletal muscles:

structural and functional aspects. Acta Physiologica, 188(2), 77-89.

http://doi.org/10.1111/j.1748-1716.2006.01613.x

Bottaro, M., Machado, S. N., Nogueira, W., Scales, R., \& Veloso, J. (2007). Effect of high versus low-velocity resistance training on muscular fitness and functional performance in older men. European Journal of Applied Physiology, 99(3), 257-

264. https://doi.org/10.1007/s00421-006-0343-1

Bouzid, M. A., Filaire, E., McCall, A., \& Fabre, C. (2015). Radical oxygen species, exercise and aging: an update. Sports Medicine, 45(9), 1245-1261. http://dx.doi.org/10.1007/s40279-015-0348-1

Bowen, T. S., Schuler, G., \& Adams, V. (2015). Skeletal muscle wasting in cachexia and sarcopenia: molecular pathophysiology and impact of exercise training. Journal of Cachexia, Sarcopenia and Muscle, 6(3), 197-207.

http://dx.doi.org/10.1002/jcsm.12043

Brosnan, M. E., \& Brosnan, J. T. (2016). The role of dietary creatine. Amino Acids, 48(8), 1785-1791. http://dx.doi.org/10.1007/s00726-016-2188-1

Brown, A. B., McCartney, N., \& Sale, D. G. (1990). Positive adaptations to weight-lifting training in the elderly. Journal of Applied Physiology, 69(5), 1725-1733. http://doi.org/10.1152/jappl.1990.69.5.1725 
Buresh, R., Berg, K., \& French, J. (2009). The effect of resistive exercise rest interval on hormonal response, strength, and hypertrophy with training. The Journal of Strength \& Conditioning Research, 23(1), 62-71. http://dx.doi.org/10.1519/JSC.0b013e318185f14a

Burke, D. G., Candow, D. G., Chilibeck, P. D., MacNeil, L. G., Roy, B. D., Tarnopolsky, M. A., \& Ziegenfuss, T. (2008). Effect of creatine supplementation and resistance-exercise training on muscle insulin-like growth factor in young adults. International Journal of Sport Nutrition and Exercise Metabolism, 18(4), 389-398. http://dx.doi.org/10.1123/ijsnem.18.4.389

Candow, D. G. (2011). Sarcopenia: current theories and the potential beneficial effect of creatine application strategies. Biogerontology, 12(4), 273-281. http://dx.doi.org/10.1007/s10522-011-9327-6

Candow, D. G., \& Chilibeck, P. D. (2005). Differences in size, strength, and power of upper and lower body muscle groups in young and older men. The Journals of Gerontology Series A: Biological Sciences and Medical Sciences, 60(2), 148-156. http://doi.org/10.1093/gerona/60.2.148

Candow, D. G., \& Chilibeck, P. D. (2008). Timing of creatine or protein supplementation and resistance training in the elderly. Applied Physiology, Nutrition, and Metabolism, 33(1), 184-190. http://doi.org/10.1139/H07-139

Candow, D. G., Chilibeck, P. D., Burke, D. G., Davison, S. K., \& Smith-Palmer, T. (2001). Effect of glutamine supplementation combined with resistance training in young adults. European Journal of Applied Physiology, 86(2), 142-149. http://doi.org/10.1007/s00421-001-0523-y 
Candow, D. G., Chilibeck, P. D., Facci, M., Abeysekara, S., \& Zello, G. A. (2006).

Protein supplementation before and after resistance training in older men. European Journal of Applied Physiology, 97(5), 548-556.

http://doi.org/10.1007/s00421-006-0223-8

Candow, D. G., Chilibeck, P. D., \& Forbes, S. C. (2014). Creatine supplementation and aging musculoskeletal health. Endocrine, 45(3), 354-361. http://dx.doi.org/10.1007/s12020-013-0070-4

Candow, D. G., Forbes, S. C., Little, J. P., Cornish, S. M., Pinkoski, C., \& Chilibeck, P. D. (2012). Effect of nutritional interventions and resistance exercise on aging muscle mass and strength. Biogerontology, 13(4), 345-358. http://dx.doi.org/10.1007/s10522-012-9385-4

Candow, D. G., Little, J. P., Chilibeck, P. D., Abeysekara, S., Zello, G. A., Kazachkov, M., ... \& Yu, P. H. (2008). Low-dose creatine combined with protein during resistance training in older men. Medicine \& Science in Sports \& Exercise, 40(9), 1645-1652. http://dx.doi.org/10.1249/MSS.0b013e318176b310

Candow, D. G., Vogt, E., Johannsmeyer, S., Forbes, S. C., \& Farthing, J. P. (2015). Strategic creatine supplementation and resistance training in healthy older adults. Applied Physiology, Nutrition, and Metabolism, 40(7), 689-694. https://doi.org/10.1139/apnm-2014-0498

Candow, D. G., Zello, G. A., Ling, B., Farthing, J. P., Chilibeck, P. D., McLeod, K., ... \& Johnson, S. (2014). Comparison of creatine supplementation before versus after supervised resistance training in healthy older adults. Research in Sports Medicine, 22(1), 61-74. http://doi.org/10.1080/15438627.2013.852088 
Caserotti, P., Aagaard, P., Buttrup Larsen, J., \& Puggaard, L. (2008). Explosive heavyresistance training in old and very old adults: changes in rapid muscle force, strength and power. Scandinavian Journal of Medicine \& Science in Sports, 18(6), 773-782. http://dx.doi.org/10.1111/j.1600-0838.2007.00732.x

Casey, A., Constantin-Teodosiu, D., Howell, S., Hultman, E. G. P. L., \& Greenhaff, P. L. (1996a). Creatine ingestion favorably affects performance and muscle metabolism during maximal exercise in humans. American Journal of PhysiologyEndocrinology and Metabolism, 271(1), E31-E37. http://doi.org/10.1152/ajpendo.1996.271.1.E31

Casey, A., Constantin-Teodosiu, D., Howell, S., Hultman, E. G. P. L., \& Greenhaff, P. L. (1996b). Metabolic response of type I and II muscle fibers during repeated bouts of maximal exercise in humans. American Journal of Physiology-Endocrinology and Metabolism, 271(1), E38-E43. http://doi.org/10.1152/ajpendo.1996.271.1.E38

Chalé, A., Cloutier, G. J., Hau, C., Phillips, E. M., Dallal, G. E., \& Fielding, R. A. (2013). Efficacy of whey protein supplementation on resistance exercise-induced changes in lean mass, muscle strength, and physical function in mobility-limited older adults. Journals of Gerontology Series A: Biomedical Sciences and Medical Sciences, 68(6), 682-690. http://doi.org/10.1093/gerona/gls221

Cheema, B. S., Chan, D., Fahey, P., \& Atlantis, E. (2014). Effect of progressive resistance training on measures of skeletal muscle hypertrophy, muscular strength and health-related quality of life in patients with chronic kidney disease: a systematic review and meta-analysis. Sports Medicine, 44(8), 1125-1138. http://dx.doi.org/10.1007/s40279-014-0176-8 
Chilibeck, P.D., Kaviani, M., Candow, D.G., Zello, G.A. (2017). Effect of creatine supplementation during resistance training on lean tissue mass and muscular strength in older adults: a meta-analysis. Open Access Journal of Sports Medicine, 2017(8), 213-226. http://doi.org/10.2147/OAJSM.S123529

Clark, B. C., \& Manini, T. M. (2008). Sarcopenia $\neq$ dynapenia. The Journals of Gerontology Series A: Biological Sciences and Medical Sciences, 63(8), 829-834. http://doi.org/10.1093/gerona/63.8.829

Clark, B. C., \& Manini, T. M. (2012). What is dynapenia?. Nutrition, 28(5), 495-503. http://doi.org/10.1016/j.nut.2011.12.002

Cruz-Jentoft, A. J., Baeyens, J. P., Bauer, J. M., Boirie, Y., Cederholm, T., Landi, F., ... \& Topinková, E. (2010). Sarcopenia: European consensus on definition and diagnosis Report of the European Working Group on Sarcopenia in Older People. Age and Ageing, 39(4), 412-423. http://dx.doi.org/10.1093/ageing/afq034

Cruz-Jentoft, A. J., Landi, F., Schneider, S. M., Zúñiga, C., Arai, H., Boirie, Y., ... \& Sieber, C. (2014). Prevalence of and interventions for sarcopenia in ageing adults: a systematic review. Report of the International Sarcopenia Initiative (EWGSOP and IWGS). Age and Ageing, 43(6), 748-759. http://dx.doi.org/10.1093/ageing/afu115

Davies, T. B., Kuang, K., Orr, R., Halaki, M., \& Hackett, D. (2017). Effect of movement velocity during resistance training on dynamic muscular strength: a systematic review and meta-analysis. Sports Medicine, 1-15. http://dx.doi.org/10.1007/s40279-017-0676-4 
de Bandt, J. P. (2016). Leucine and mammalian target of rapamycin-dependent activation of muscle protein synthesis in aging. The Journal of Nutrition, 146(12), 2616S2624S. http://dx.doi.org/10.3945/jn.116.234518

de Vos, N. J., Singh, N. A., Ross, D. A., Stavrinos, T. M., Orr, R., \& Fiatarone Singh, M. A. (2005). Optimal load for increasing muscle power during explosive resistance training in older adults. The Journals of Gerontology Series A: Biological Sciences and Medical Sciences, 60(5), 638-647. http://dx.doi.org/10.1093/gerona/60.5.638

Deldicque, L., Louis, M., Theisen, D., Nielens, H., Dehoux, M., Thissen, J. P., ... \& Francaux, M. (2005). Increased IGF mRNA in human skeletal muscle after creatine supplementation. Medicine and Science in Sports and Exercise, 37(5), 731-736. http://dx.doi.org/10.1249/01.MSS.0000162690.39830.27

Deminice, R., \& Jordao, A. A. (2012). Creatine supplementation reduces oxidative stress biomarkers after acute exercise in rats. Amino Acids, 43(2), 709-715. https://doi.org/10.1007/s00726-011-1121-x

Devries, M. C., \& Phillips, S. M. (2014). Creatine supplementation during resistance training in older adults - a meta-analysis. Medicine \& Science in Sports \& Exercise, 46(6), 1194-1203. http://dx.doi.org/10.1249/MSS.0000000000000220

Earles, D. R., Judge, J. O., \& Gunnarsson, O. T. (2001). Velocity training induces powerspecific adaptations in highly functioning older adults. Archives of Physical Medicine and Rehabilitation, 82(7), 872-878. http://dx.doi.org/10.1053/apmr.2001.23838

Evans, W. J., \& Lexell, J. (1995). Human aging, muscle mass, and fiber type composition. The Journals of Gerontology Series A: Biological Sciences and 
Medical Sciences, 50(Special Issue), 11-

16. http://doi.org/10.1093/gerona/50A.Special_Issue.11

Farthing, J. P., \& Chilibeck, P. D. (2003). The effect of eccentric training at different velocities on cross-education. European Journal of Applied Physiology, 89(6), 570-577. http://doi.org/10.1007/s00421-003-0841-3

Faul, F., Erdfelder, E., Lang, A. G., \& Buchner, A. (2007). G* Power 3: A flexible statistical power analysis program for the social, behavioral, and biomedical sciences. Behavior Research Methods, 39(2), 175-191. http://dx.doi.org/10.3758/BF03193146

Fielding, R. A., LeBrasseur, N. K., Cuoco, A., Bean, J., Mizer, K., \& Singh, M. A. F. (2002). High-velocity resistance training increases skeletal muscle peak power in older women. Journal of the American Geriatrics Society, 50(4), 655-662. http://dx.doi.org/10.1046/j.1532-5415.2002.50159.x

Fielding, R. A., Vellas, B., Evans, W. J., Bhasin, S., Morley, J. E., Newman, A. B., ... \& Cederholm, T. (2011). Sarcopenia: an undiagnosed condition in older adults. Current consensus definition: prevalence, etiology, and consequences. International working group on sarcopenia. Journal of the American Medical Directors Association, 12(4), 249-256.

http://dx.doi.org/10.1016/j.jamda.2011.01.003

Fimognari, C., Sestili, P., Lenzi, M., Cantelli-Forti, G., \& Hrelia, P. (2009). Protective effect of creatine against RNA damage. Mutation Research/Fundamental and Molecular Mechanisms of Mutagenesis, 670(1), 59-67. http://dx.doi.org/10.1016/j.mrfmmm.2009.07.005 
SUPPLEMENTATION IN UNTRAINED HEALTHY AGING MALE

Foldvari, M., Clark, M., Laviolette, L. C., Bernstein, M. A., Kaliton, D., Castaneda, C., ... \& Singh, M. A. F. (2000). Association of muscle power with functional status in community-dwelling elderly women. The Journals of Gerontology Series A:

Biological Sciences and Medical Sciences, 55(4), M192-M199.

http://dx.doi.org/10.1093/gerona/55.4.M192

Forbes, S. C., \& Candow, D. G. (2018). Timing of Creatine Supplementation and Resistance Training: A Brief Review. Journal of Exercise and Nutrition, 1(5), 16.

Forsberg, A. M., Nilsson, E., Werneman, J., Bergström, J., \& Hultman, E. (1991). Muscle composition in relation to age and sex. Clinical Science, 81(2), 249-256. http://dx.doi.org/10.1042/cs0810249

Fry, C. S., Drummond, M. J., Glynn, E. L., Dickinson, J. M., Gundermann, D. M., Timmerman, K. L., ... \& Rasmussen, B. B. (2011). Aging impairs contractioninduced human skeletal muscle mTORC1 signaling and protein synthesis. Skeletal Muscle, 1(1), 11. http://dx.doi.org/10.1186/2044-5040-1-11

Fujita, S., Abe, T., Drummond, M. J., Cadenas, J. G., Dreyer, H. C., Sato, Y., ... \& Rasmussen, B. B. (2007). Blood flow restriction during low-intensity resistance exercise increases S6K1 phosphorylation and muscle protein synthesis. Journal of Applied Physiology, 103(3), 903-910.

https://doi.org/10.1152/japplphysiol.00195.2007

Greenhaff, P. L., Nevill, M. E., Soderlund, K., Bodin, K., Boobis, L. H., Williams, C., \& Hultman, E. (1994). The metabolic responses of human type I and II muscle fibres during maximal treadmill sprinting. The Journal of Physiology, 478(Pt 1), 149. http://dx.doi.org/10.1113/jphysiol.1994.sp020238 
Godin, G., \& Shephard, R. J. (1985). A simple method to assess exercise behavior in the community. Canadian Journal of Applied Sport Sciences, 10(3), 141-146.

Goldspink, G. (2005). Mechanical signals, IGF-I gene splicing, and muscle adaptation. Physiology, 20(4), 232-238.

http://dx.doi.org/10.1152/physiol.00004.2005

Gomes, E. C., Silva, A. N., \& Oliveira, M. R. D. (2012). Oxidants, antioxidants, and the beneficial roles of exercise-induced production of reactive species. Oxidative Medicine and Cellular Longevity, 2012. http://dx.doi.org/10.1155/2012/756132

Gualano, B., Artioli, G. G., Poortmans, J. R., \& Junior, A. H. L. (2010). Exploring the therapeutic role of creatine supplementation. Amino Acids, 38(1), 31-44. http://dx.doi.org/10.1007/s00726-009-0263-6

Gualano, B., Rawson, E. S., Candow, D. G., \& Chilibeck, P. D. (2016). Creatine supplementation in the aging population: effects on skeletal muscle, bone and brain. Amino Acids, 48(8), 1793-1805. http://doi.org/10.1007/s00726-016-2239-7

Häkkinen, K., Kraemer, W. J., Newton, R. U., \& Alen, M. (2001). Changes in electromyographic activity, muscle fibre and force production characteristics during heavy resistance/power strength training in middle-aged and older men and women. Acta Physiologica, 171(1), 51-62. http://dx.doi.org/10.1046/j.1365201X.2001.00781.X

Hameed, M., Lange, K. H. W., Andersen, J. L., Schjerling, P., Kjaer, M., Harridge, S. D. R., \& Goldspink, G. (2004). The effect of recombinant human growth hormone and resistance training on IGF-I mRNA expression in the muscles of elderly men. The Journal of Physiology, 555(1), 231-240.

http://dx.doi.org/10.1113/jphysiol.2003.051722 
Henneman, E. (1957). Relation between size of neurons and their susceptibility to discharge. Science, 126(3287), 1345-1347.

Janssen, I., Shepard, D. S., Katzmarzyk, P. T., \& Roubenoff, R. (2004). The healthcare costs of sarcopenia in the United States. Journal of the American Geriatrics Society, 52(1), 80-85. http://dx.doi.org/10.1111/j.1532-5415.2004.52014.x

Johannsmeyer, S., Candow, D. G., Brahms, C. M., Michel, D., \& Zello, G. A. (2016). Effect of creatine supplementation and drop-set resistance training in untrained aging adults. Experimental Gerontology, 83, 112-119. http://dx.doi.org/10.1016/j.exger.2016.08.005

Johnston, A. P., De Lisio, M., \& Parise, G. (2007). Resistance training, sarcopenia, and the mitochondrial theory of aging. Applied Physiology, Nutrition, and Metabolism, 33(1), 191-199. http://dx.doi.org/10.1139/H07-141

Kadi, F., Charifi, N., Denis, C., \& Lexell, J. (2004). Satellite cells and myonuclei in young and elderly women and men. Muscle \& Nerve, 29(1), 120-127. http://dx.doi.org/10.1002/mus.10510

Karakelides, H., \& Nair, K. S. (2005). Sarcopenia of aging and its metabolic impact. Current Topics in Developmental Biology, 68, 123-148. http://dx.doi.org/10.1016/S0070-2153(05)68005-2

Kraemer, W. J., \& Ratamess, N. A. (2005). Hormonal responses and adaptations to resistance exercise and training. Sports Medicine, 35(4), 339-361. http://doi.org/10.2165/00007256-200535040-00004

Kreider, R. B., Kalman, D. S., Antonio, J., Ziegenfuss, T. N., Wildman, R., Collins, R., ... Lopez, H. L. (2017). International Society of Sports Nutrition position stand: safety and efficacy of creatine supplementation in exercise, sport, and medicine. 
Journal of the International Society of Sports Nutrition, 14(1), 18.

http://dx.doi.org/10.1186/s12970-017-0173-z

Kumar, V., Selby, A., Rankin, D., Patel, R., Atherton, P., Hildebrandt, W., ... \& Rennie, M. J. (2009). Age-related differences in the dose-response relationship of muscle protein synthesis to resistance exercise in young and old men. The Journal of Physiology, 587(1), 211-217. http://dx.doi.org10.1113/jphysiol.2008.164483

Ladner, K. J., Caligiuri, M. A., \& Guttridge, D. C. (2003). Tumor necrosis factorregulated biphasic activation of NF- $\mathrm{BB}$ is required for cytokine-induced loss of skeletal muscle gene products. Journal of Biological Chemistry, 278(4), 22942303. http://dx.doi.org/10.1074/jbc.M207129200

Laplante, M., \& Sabatini, D. M. (2012). mTOR signaling in growth control and disease. Cell, 149(2), 274-293. http://dx.doi.org/10.1016/j.cell.2012.03.017

Little, J. P., \& Phillips, S. M. (2009). Resistance exercise and nutrition to counteract muscle wasting. Applied Physiology, Nutrition, and Metabolism, 34(5), 817-828. http://doi.org/10.1139/H09-093

Manini, T. M., \& Clark, B. C. (2013). What we have learned from exercise and lifestyle trials to alleviate mobility impairment in older adults. The Journal of Frailty \& Aging, 2(1), 57.

Marsh, A. P., Miller, M. E., Rejeski, W. J., Hutton, S. L., \& Kritchevsky, S. B. (2009). Lower extremity muscle function after strength or power training in older adults. Journal of Aging and Physical Activity, 17(4), 416-443.

http://dx.doi.org/10.1123/japa.17.4.416 
Marzetti, E., Calvani, R., Tosato, M., Cesari, M., Di Bari, M., Cherubini, A., ... \& Landi, F. (2017). Sarcopenia: an overview. Aging Clinical and Experimental Research, 1-7. http://dx.doi.org/10.1007/s40520-016-0704-5

McCully, K., \& Posner, J. (1992). Measuring exercise-induced adaptations and injury with magnetic resonance spectroscopy. International Journal of Sports Medicine, 13(Suppl. 1), S147-S149. http://dx.doi.org/10.1055/s-2007-1024621

McKinnon, N. B., Connelly, D. M., Rice, C. L., Hunter, S. W., \& Doherty, T. J. (2017).

Neuromuscular contributions to the age-related reduction in muscle power: mechanisms and potential role of high velocity power training. Ageing Research Reviews, 35, 147-154. http://dx.doi.org/10.1016/j.arr.2016.09.003

Miyatani, M., Kanehisa, H., \& Fukunaga, T. (2000). Validity of bioelectrical impedance and ultrasonographic methods for estimating the muscle volume of the upper arm. European Journal of Applied Physiology, 82(5-6), 391-396. http://doi.org/10.1007/s004210000213

Miyatani, M., Kanehisa, H., Kuno, S., Nishijima, T., \& Fukunaga, T. (2002). Validity of ultrasonograph muscle thickness measurements for estimating muscle volume of knee extensors in humans. European Journal of Applied Physiology, 86(3), 203208. http://doi.org/10.1007/s00421-001-0533-9

Möller, P., Bergström, J., Fürst, P., \& Hellström, K. (1980). Effect of aging on energyrich phosphagens in human skeletal muscles. Clinical Science, 58(6), 553-555. http://dx.doi.org/10.1042/cs0580553

Morton, R. W., Murphy, K. T., McKellar, S. R., Schoenfeld, B. J., Henselmans, M., Helms, E., ... \& Phillips, S. M. (2018). A systematic review, meta-analysis and meta-regression of the effect of protein supplementation on resistance training- 
EFFECTS OF HIGH-VELOCITY RESISTANCE TRAINING AND CREATINE 66 SUPPLEMENTATION IN UNTRAINED HEALTHY AGING MALE

induced gains in muscle mass and strength in healthy adults. British Journal of Sports Medicine, 52(6), 376-384. http://dx.doi.org/10.1136/bjsports-2017-097608

Mosole, S., Carraro, U., Kern, H., Loefler, S., Fruhmann, H., Vogelauer, M., ... \& Hamar, D. (2014). Long-term high-level exercise promotes muscle reinnervation with age. Journal of Neuropathology \& Experimental Neurology, 73(4), 284-294. http://doi.org/10.1097/NEN.0000000000000032

Moss, F. P., \& Leblond, C. P. (1971). Satellite cells as the source of nuclei in muscles of growing rats. The Anatomical Record, 170(4), 421-435. https://doi.org/10.1002/ar.1091700405

Narici, M. V., \& Maffulli, N. (2010). Sarcopenia: characteristics, mechanisms and functional significance. British Medical Bulletin, 95(1), 139-159. http://doi.org/10.1093/bmb/ldq008

Niess, A. M., \& Simon, P. (2007). Response and adaptation of skeletal muscle to exercise-the role of reactive oxygen species. Frontiers in Bioscience, 12(12), 4826-4838. http://doi.org/10.2741/2431

Newman, A. B., Kupelian, V., Visser, M., Simonsick, E. M., Goodpaster, B. H., Kritchevsky, S. B., ... \& Harris, T. B. (2006). Strength, but not muscle mass, is associated with mortality in the health, aging and body composition study cohort. The Journals of Gerontology Series A: Biological Sciences and Medical Sciences, 61(1), 72-77. http://dx.doi.org/10.1093/gerona/61.1.72

Nogueira, W., Gentil, P., Mello, S. N. M., Oliveira, R. J., Bezerra, A. J. C., \& Bottaro, M. (2009). Effects of power training on muscle thickness of older men. International Journal of Sports Medicine, 30(03), 200-204. http://dx.doi.org/10.1055/s-0028$\underline{1104584}$ 
Olsen, S., Aagaard, P., Kadi, F., Tufekovic, G., Verney, J., Olesen, J. L., ... \& Kjær, M. (2006). Creatine supplementation augments the increase in satellite cell and myonuclei number in human skeletal muscle induced by strength training. The Journal of Physiology, 573(2), 525-534.

http://dx.doi.org/10.1113/jphysiol.2006.107359

Owino, V., Yang, S. Y., \& Goldspink, G. (2001). Age-related loss of skeletal muscle function and the inability to express the autocrine form of insulin-like growth factor-1 (MGF) in response to mechanical overload. FEBS Letters, 505(2), 259263. http://dx.doi.org/10.1016/S0014-5793(01)02825-3

Parise, G., Mihic, S., MacLennan, D., Yarasheski, K. E., \& Tarnopolsky, M. A. (2001). Effects of acute creatine monohydrate supplementation on leucine kinetics and mixed-muscle protein synthesis. Journal of Applied Physiology, 91(3), 10411047. https://doi.org/10.1152/jappl.2001.91.3.1041

Phillips, S. M., Chevalier, S., \& Leidy, H. J. (2016). Protein "requirements" beyond the RDA: implications for optimizing health. Applied Physiology, Nutrition, and Metabolism, 41(5), 565-572. https://doi.org/10.1139/apnm-2015-0550

Ratamess, N.A., Alvar, B.A., Evetoch, T. E., Housh, T. J., Kibler, B. W., Kraemer, W. J., Triplett, T. N. (2009). Progression models in resistance training for healthy adults. Medicine and Science in Sports and Exercise, 41(3), 687-708. http://dx.doi.org/10.1249/MSS.0b013e3181915670

Reid, K. F., Callahan, D. M., Carabello, R. J., Phillips, E. M., Frontera, W. R., \& Fielding, R. A. (2008). Lower extremity power training in elderly subjects with mobility limitations: a randomized controlled trial. Aging Clinical and Experimental Research, 20(4), 337. 
Reid, K. F., \& Fielding, R. A. (2012). Skeletal muscle power: a critical determinant of physical functioning in older adults. Exercise and Sport Sciences Reviews, 40(1), 4. http://dx.doi.org/10.1097/JES.0b013e31823b5f13

Rennie, M. J., \& Tipton, K. D. (2000). Protein and amino acid metabolism during and after exercise and the effects of nutrition. Annual Review of Nutrition, 20(1), 457483. http://dx.doi.org/10.1146/annurev.nutr.20.1.457

Roubenoff, R. (2003). Sarcopenia: effects on body composition and function. The Journals of Gerontology Series A: Biological Sciences and Medical Sciences, 58(11), M1012-M1017. http://dx.doi.org/10.1093/gerona/58.11.M1012

Ryall, J. G., Schertzer, J. D., \& Lynch, G. S. (2008). Cellular and molecular mechanisms underlying age-related skeletal muscle wasting and weakness. Biogerontology, 9(4), 213-228. http://dx.doi.org/10.1007/s10522-008$\underline{9131-0}$

Sabourin, L. A., \& Rudnicki, M. A. (2000). The molecular regulation of myogenesis. Clinical Genetics, 57(1), 16-25. http://dx.doi.org/10.1034/j.1399$\underline{0004.2000 .570103 . x}$

Safdar, A., Yardley, N. J., Snow, R., Melov, S., \& Tarnopolsky, M. A. (2008). Global and targeted gene expression and protein content in skeletal muscle of young men following short-term creatine monohydrate supplementation. Physiological Genomics, 32(2), 219-228. http://dx.doi.org/10.1152/physiolgenomics.00157.2007

Sajko, Š., Kubínová, L., Cvetko, E., Kreft, M., Wernig, A., \& Eržen, I. (2004). Frequency of M-cadherin-stained satellite cells declines in human muscles during 
aging. Journal of Histochemistry \& Cytochemistry, 52(2), 179-185.

http://dx.doi.org/10.1177/002215540405200205

Sale, D. G. (1987). Influence of exercise and training on motor unit activation. Exercise and Sport Sciences Reviews, 15, 95-151.

Sale, D. G. (1988). Neural adaptation to resistance training. Medicine and Science in Sports and Exercise, 20(5 Suppl), S135-45.

Sale, D. G. (2008). Neural adaptation to strength training. Strength and Power in Sport, Second Edition, 281-314. http://dx.doi.org/10.1002/9780470757215.ch15

Sandri, M. (2008). Signaling in muscle atrophy and hypertrophy. Physiology, 23(3), 160170. http://dx.doi.org/10.1152/physiol.00041.2007

Santacruz, L., \& Jacobs, D. O. (2016). Structural correlates of the creatine transporter function regulation: the undiscovered country. Amino Acids, 48(8), 2049-2055. http://dx.doi.org/10.1007/s00726-016-2206-3

Sarbassov, D. D., Ali, S. M., \& Sabatini, D. M. (2005). Growing roles for the mTOR pathway. Current Opinion in Cell Biology, 17(6), 596-603.

http://doi.org/10.1016/j.ceb.2005.09.009

Scelsi, R., Marchetti, C., \& Poggi, P. (1980). Histochemical and ultrastructural aspects of m. vastus lateralis in sedentary old people (age 65-89 years). Acta Neuropathologica, 51(2), 99-105. http://doi.org/10.1007/BF00690450

Schlattner, U., Klaus, A., Rios, S. R., Guzun, R., Kay, L., \& Tokarska-Schlattner, M. (2016). Cellular compartmentation of energy metabolism: creatine kinase microcompartments and recruitment of B-type creatine kinase to specific subcellular sites. Amino Acids, 48(8), 1751-1774.

http://dx.doi.org/10.1007/s00726-016-2267-3 
Schoenfeld, B. J. (2010). The mechanisms of muscle hypertrophy and their application to resistance training. The Journal of Strength \& Conditioning Research, 24(10), 2857-2872. http://dx.doi.org/10.1519/JSC.0b013e3181e840f3

Sinha-Hikim, I., Cornford, M., Gaytan, H., Lee, M. L., \& Bhasin, S. (2006). Effects of testosterone supplementation on skeletal muscle fiber hypertrophy and satellite cells in community-dwelling older men. The Journal of Clinical Endocrinology \& Metabolism, 91(8), 3024-3033. http://doi.org/10.1210/jc.2006-0357

Skelton, D. A., Greig, C. A., Davies, J. M., \& Young, A. (1994). Strength, power and related functional ability of healthy people aged 65-89 years. Age and Ageing, 23(5), 371-377. http://doi.org/10.1093/ageing/23.5.371

Syrotuik, D. G., \& Bell, G. J. (2004). Acute Creatine Monohydrate Supplementation: A descriptive physiological profile of responders vs. nonresponders. The Journal of Strength \& Conditioning Research, 18(3), 610-617.

Tarnopolsky, M. A. (2000). Gender differences in metabolism; nutrition and supplements. Journal of Science and Medicine in Sport, 3(3), 287-298. http://dx.doi.org/10.1016/S1440-2440(00)80038-9

Tarnopolsky, M. A., \& Maclennan, D. P. (2000). Creatine monohydrate supplementation enhances high-intensity exercise performance in males and females. International Journal of Sport Nutrition and Exercise Metabolism, 10(4), 452-463.

http://dx.doi.org/10.1123/ijsnem.10.4.452

Terjung, R. L., Clarkson, P., Eichner, E. R., Greenhaff, P. L., Hespel, P. J., Israel, R. G., ... \& Wagenmakers, A. J. (2000). American College of Sports Medicine roundtable. The physiological and health effects of oral creatine 
supplementation. Medicine and Science in Sports and Exercise, 32(3), 706-717. http://dx.doi.org/10.1097/00005768-200003000-00024

Thom, J. M., Morse, C. I., Birch, K. M., \& Narici, M. V. (2007). Influence of muscle architecture on the torque and power-velocity characteristics of young and elderly men. European Journal of Applied Physiology, 100(5), 613-619. http://doi.org/10.1007/s00421-007-0481-0

Thorstensson, A., Hultén, B., Döbeln, W. V., \& Karlsson, J. (1976). Effect of strength training on enzyme activities and fibre characteristics in human skeletal muscle. Acta Physiologica Scandinavica, 96(3), 392-398. http://doi.org/10.1111/j.1748-1716.1976.tb10207.x

Toigo, M., \& Boutellier, U. (2006). New fundamental resistance exercise determinants of molecular and cellular muscle adaptations. European Journal of Applied Physiology, 97(6), 643-663. https://doi.org/10.1007/s00421-006-0238-1

Trappe, S., Gallagher, P., Harber, M., Carrithers, J., Fluckey, J., \& Trappe, T. (2003). Single muscle fibre contractile properties in young and old men and women. The Journal of Physiology, 552(1), 47-58.

http://dx.doi.org/10.1113/jphysiol.2003.044966

Trappe, T. A., White, F., Lambert, C. P., Cesar, D., Hellerstein, M., \& Evans, W. J. (2002). Effect of ibuprofen and acetaminophen on postexercise muscle protein synthesis. American Journal of Physiology-Endocrinology and Metabolism, 282(3), E551-E556. http://dx.doi.org/10.1152/ajpendo.00352.2001

Traylor, D. A., Gorissen, S. H., \& Phillips, S. M. (2018). Perspective: protein requirements and optimal intakes in aging: are we ready to recommend more than 
EFFECTS OF HIGH-VELOCITY RESISTANCE TRAINING AND CREATINE SUPPLEMENTATION IN UNTRAINED HEALTHY AGING MALE

the recommended daily allowance?. Advances in Nutrition, 9(3), 171-182. http://doi.org/10.1093/advances/nmy003

van Kan, G. A. (2009). Epidemiology and consequences of sarcopenia. JNHA-The Journal of Nutrition, Health and Aging, 13(8), 708-712. https://doi.org/10.1007/s12603-009-0201-z

Wallimann, T., Tokarska-Schlattner, M., \& Schlattner, U. (2011). The creatine kinase system and pleiotropic effects of creatine. Amino Acids, 40(5), 1271-1296. http://dx.doi.org/10.1007/s00726-011-0877-3

Waters, M. J., Shang, C. A., Behncken, S. N., Tam, S. P., Li, H., Shen, B., \& Lobie, P. E. (1999). Growth hormone as a cytokine. Clinical and Experimental Pharmacology and Physiology, 26(10), 760-764. http://dx.doi.org/10.1046/j.14401681.1999.03129.x

Weisgarber, K. D., Candow, D. G., \& Farthing, J. P. (2015). Whey protein and highvolume resistance training in postmenopausal women. The Journal of Nutrition, Health \& Aging, 19(5), 511. http://doi.org/10.1007/s1260

Willoughby, D. S., \& Rosene, J. M. (2003). Effects of oral creatine and resistance training on myogenic regulatory factor expression. Medicine and Science in Sports and Exercise, 35(6), 923-929. http://dx.doi.org/10.1249/01.MSS.0000069746.05241.F0

Wyss, M., \& Kaddurah-Daouk, R. (2000). Creatine and creatinine metabolism. Physiological Reviews, 80(3), 1107-1213.

Zanou, N., \& Gailly, P. (2013). Skeletal muscle hypertrophy and regeneration: interplay between the myogenic regulatory factors (MRFs) and insulin-like growth factors 
(IGFs) pathways. Cellular and Molecular Life Sciences, 70(21), 4117-4130.

http://doi.org/10.1007/s00018-013-1330-4 


\title{
EFFECTS OF HIGH-VELOCITY RESISTANCE TRAINING AND CREATINE SUPPLEMENTATION IN UNTRAINED HEALTHY AGING MALE
}

\section{Appendix A: PAR-Q+ and PARMED-X}

\author{
CSEP approved Sept 122011 version
}

\section{PAR-Q+}

\section{The Physical Activity Readiness Questionnaire for Everyone}

Regular physical activity is fun and healthy, and more pecple should become more physically active every day of the week Eeing more physically active is very safe for MOST pecple. This questionnaire will tell you whether it is necessary for you to seek further advice from your doctor OR a qualifed exercise professional before becorning more physically active.

\section{SECTION 1 - GENERAL HEALTH}

\begin{tabular}{|c|c|c|c|}
\hline \multicolumn{2}{|r|}{ Please read the 7 questions below carefully and answer each ene honestly: check YES or NO. } & \multirow{2}{*}{$\begin{array}{l}\text { YES } \\
\square\end{array}$} & \multirow{2}{*}{$\frac{\mathrm{NO}}{\square}$} \\
\hline 1. & Has your decter ever said thet you have a heart condition OR high blocd pressure? & & \\
\hline 2. & $\begin{array}{l}\text { Do you feel pain in your chest at rest, during your daily activities of living, OR when you do physical } \\
\text { activity? }\end{array}$ & 미 & $\square$ \\
\hline 3. & $\begin{array}{l}\text { Do you lose balance because of diaziness OR have you lost consciousness in the last } 12 \text { months? Please } \\
\text { answer NO f your dicziress wess associated with orec-breathing (including during vigorous exercise). }\end{array}$ & $\Pi$ & $\square$ \\
\hline 4. & $\begin{array}{l}\text { Hove you ever been diagnosed with another chronic medical condition } \\
\text { (other than heart disease or high blood pressure)? }\end{array}$ & 口 & $\square$ \\
\hline 5. & Are you currently taking prescribed medications for a chronic medical condition? & 드 & $\square$ \\
\hline$\Delta$. & $\begin{array}{l}\text { Do you have a bone or joint problem that could be made worse by becoming more physically active? } \\
\text { Plesse answer NO if you had a joint problem in the past, but it does not limit your current ability to be } \\
\text { physically active. For example, knee, ankle, shoulder or other }\end{array}$ & $\square$ & $\square$ \\
\hline 7. & Hes your doctor ever said that you should only do medically supervised physical activity? & $\square$ & $\square$ \\
\hline
\end{tabular}

If you answered NO to all of the questions above, you are cleared for physical activity.

Go to Section 3 to sign the form. You do not need to complete Section 2.

3t Start becoming much more physically active - start slowly and build up gradually.

3. Follow the Cansdian Physical Activity Guidelines for your age (www.csep.ca/guidelines)

You may taice part in a health and fitness appraisal.

3. If you have any further questions, contact a qualified exercise professional such as a CSEP Certified Exercise Physiologist*a (CSEP-CEP) or CSEP Certified Personal Trainert [CSEP-CPT].

3. If you are over the age of $45 \mathrm{yrz}$. and NOT sccustorned to regular vigorous physical activity, please consult a qualifed exercise professional (CSEP.CEP) before engaging in maximal effort exercise

If you answered YES to one or more of the questions above, please GO TO SECTION 2.

Delay becoming more active if:

3. You are not feeling well because of a temporary illness such as a cold or fever - wait until you feel better

3 You are pregnant - talk to your health care practitioner, your physician, a qualified exercise professionsl, and/or complete the PARmed X for Pregnancy before becoming more physically active $\mathrm{OR}$

3. Your health changes - please answer the questions on Section 2 of this document and/or talk to your doctor or qualified exercise professional (CSEP-CEP or CSEP-CPT) before continuing with any physical activity programme. 


\section{EFFECTS OF HIGH-VELOCITY RESISTANCE TRAINING AND CREATINE SUPPLEMENTATION IN UNTRAINED HEALTHY AGING MALE}

SECTION 2 - CHRONIC MEDICAL CONDITIONS

\begin{tabular}{|c|c|c|c|c|}
\hline \multicolumn{3}{|c|}{ Please read the questions belew carefully and answer each one honestly: check YES or NO. } & \multirow{2}{*}{$\begin{array}{c}\text { YES } \\
\square \\
\text { If yes, answer } \\
\begin{array}{c}\text { questions } \\
\text { 1a-ic }\end{array}\end{array}$} & \multirow{2}{*}{$\begin{array}{l}\mathrm{NO} \\
\square \\
\text { If no, go to } \\
\text { question } 2\end{array}$} \\
\hline 1. & Do you & hove Arthritis, Osteoperosis, or Back Problems? & & \\
\hline & 1a. & $\begin{array}{l}\text { Do you have difficulty controlling your condition with medications or other } \\
\text { physician-prescribed therapies? (Answer NO fi you are not currently taking } \\
\text { medications or other treatments) }\end{array}$ & $\square$ & $\square$ \\
\hline & 1b. & $\begin{array}{l}\text { Do you have joint problems causing pain, a recent fracture or fracture caused } \\
\text { by osteoporosis or cancer, displaced vertebra fe g, spondylelisthesisl, and/ } \\
\text { or spondylolysis/pors defect (a crack in the bory ring on the back of the spinal } \\
\text { column)? }\end{array}$ & $\square$ & 口 \\
\hline & $1 c$ & $\begin{array}{l}\text { Have you had stercid injections or taken steroid tablets regularly for more than } 3 \\
\text { monshs? }\end{array}$ & $\square$ & $\square$ \\
\hline \multirow[t]{3}{*}{2.} & \multicolumn{2}{|c|}{ Do you heve Cancer of any kind? } & $\begin{array}{l}\text { If yes, answer } \\
\text { questions } \\
2 \mathrm{a}-2 \mathrm{~b}\end{array}$ & $\begin{array}{l}\text { If no, go to } \\
\text { question } 3\end{array}$ \\
\hline & $2 a$. & $\begin{array}{l}\text { Does your cancer diagnesis include any of the follewing types lung/brenchegenic, } \\
\text { multiple myelama (concer of plasma cells), head, and neck? }\end{array}$ & $\square$ & $\square$ \\
\hline & $2 b$. & Are you currently receiving cancer therapy (such as chemotherapy or radiotherspy)? & $\square$ & $\square$ \\
\hline \multirow[t]{6}{*}{ 3. } & \multicolumn{2}{|r|}{$\begin{array}{l}\text { Do you have Heart Disease or Cardiavascular Disease? } \\
\text { This includes Coronary Artery Disease, High Blood Pressure, Heart Falure, Diagnosed } \\
\text { Abnermality of Heart Hingthm }\end{array}$} & $\begin{array}{l}\text { If yes, answer } \\
\text { questions } \\
\text { 3a-3e }\end{array}$ & $\begin{array}{l}\text { If no, go to } \\
\text { question } 4\end{array}$ \\
\hline & 3a. & $\begin{array}{l}\text { Do you have difficulty controlling your condition with medicstions or ather } \\
\text { physician-prescribed therapies? } \\
\text { (Answer NO if you ate net currently taking medications or other treasments] }\end{array}$ & 口 & 口 \\
\hline & 36. & $\begin{array}{l}\text { Do you have an irregular heart beat that requires medical mansgement? } \\
\text { \{e.g. atrial brillation, premsture ventriculor contraction\}) }\end{array}$ & $\square$ & $\square$ \\
\hline & $3 c$ & Do you have chronic heart failure? & $\square$ & $\square$ \\
\hline & 3d. & $\begin{array}{l}\text { Do you have a resting blood pressure equal to or greater than } 160 / 90 \mathrm{mmHg} \text { with or } \\
\text { without medication? (Answer YES if you do not know your resting blood pressure) }\end{array}$ & $\square$ & $\square$ \\
\hline & 3e. & $\begin{array}{l}\text { Do you have diagnosed coronary artery (cardiavascular) disease and have not } \\
\text { porticipated in regular physical activity in the last } 2 \text { montha? }\end{array}$ & 口 & 미 \\
\hline \multirow[t]{4}{*}{ 4. } & \multicolumn{2}{|c|}{$\begin{array}{l}\text { Do you hove arry Metabolic Conditions? } \\
\text { This includes Type } 1 \text { Diabetes, Type } 2 \text { Diabeses, Pre-Diabetes }\end{array}$} & $\begin{array}{l}\text { lifyes, answer } \\
\text { questions } \\
4 a-4 c\end{array}$ & $\begin{array}{l}\square \\
\text { If no, } 90 \text { to } \\
\text { question } 5\end{array}$ \\
\hline & 4a. & Is your blood sugar often above $13.0 \mathrm{mmoh}$ ? (Answer YES if you are not sure) & $\square$ & $\square$ \\
\hline & $4 b$. & $\begin{array}{l}\text { Do you have any signs or symptoms of diabetes complications such as heart } \\
\text { or vescular disease and/or complications effecting your eyes, kjidens, and the } \\
\text { sersation in your toes and feet? }\end{array}$ & $\square$ & $\square$ \\
\hline & 4c. & $\begin{array}{l}\text { Do you have other metabolic condrions (such as thyroid disorders, pregnancy- } \\
\text { reloted diebetes, chronic kidney disease, liner problems)? }\end{array}$ & $\square$ & $\square$ \\
\hline \multirow[t]{3}{*}{5.} & \multicolumn{2}{|r|}{$\begin{array}{l}\text { Do you have any Mental Hesith Problems or Learning Difficulties? } \\
\text { This includes Alzheimers, Dementib, Depression, Avwiety Diserder, Easing Disorder, } \\
\text { Psychesic Disordet, Intellectual Disability, Down Syndrome) }\end{array}$} & $\begin{array}{l}\square \\
\text { Hess, answer } \\
\text { questions } \\
58-5 b\end{array}$ & $\begin{array}{l}\square \\
\text { If no, go to } \\
\text { question } 6\end{array}$ \\
\hline & 5a. & $\begin{array}{l}\text { Do you have difficulty controlling your condition with medications or other } \\
\text { physician-prescribed therapies? (Answer NO if you are not currently taking } \\
\text { medications or other treatments) }\end{array}$ & $\square$ & $\square$ \\
\hline & Sb. & Do you also have back problems affecting nerves or muscles? & $\square$ & $\square$ \\
\hline
\end{tabular}




\section{EFFECTS OF HIGH-VELOCITY RESISTANCE TRAINING AND CREATINE SUPPLEMENTATION IN UNTRAINED HEALTHY AGING MALE}

\begin{tabular}{|c|c|c|c|c|}
\hline \multicolumn{3}{|c|}{ Please read the questions below carefully and answer each one honestly: check YES or NO. } & \multirow{2}{*}{$\begin{array}{c}\text { YES } \\
\square \\
\text { If yes, answer } \\
\text { questions } \\
\text { ba-bd }\end{array}$} & \multirow{2}{*}{ 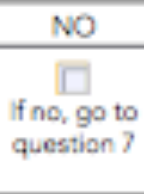 } \\
\hline 6. & \multicolumn{2}{|r|}{$\begin{array}{l}\text { Do you hove a Respiratery Disease? } \\
\text { This includes Chronic Obstructive Pulmonary Disease, Asthma, Pulmonary High Blood } \\
\text { Pressure }\end{array}$} & & \\
\hline & Ga. & $\begin{array}{l}\text { Do you have difficulty centrolling your condition with medications or other } \\
\text { physidian-prescribed therapies? } \\
\text { (Anawer NO if you are not currently taking medications or other treatments) }\end{array}$ & $\square$ & $\square$ \\
\hline & $6 b$. & $\begin{array}{l}\text { Has your decter ever said your blood exygen level is low at rest or during exercise } \\
\text { and/er that you require supplemental exygen therapy? }\end{array}$ & $\square$ & $\square$ \\
\hline & 6c. & $\begin{array}{l}\text { If asthmatic, do you currently have symptoms of chest tightness, wheezing, laboured } \\
\text { breasting, consistent cough (more than } 2 \text { days/week), or have you used your rescue } \\
\text { medication more than twice in the last week? }\end{array}$ & $\square$ & $\square$ \\
\hline & 6d. & $\begin{array}{l}\text { Has your doctor ever said you have high blood pressure in the blood vessels of your } \\
\text { lungs? }\end{array}$ & 口 & $\square$ \\
\hline \multirow[t]{4}{*}{ 7. } & \multicolumn{2}{|r|}{ Do you have a Spinal Cord Injury? This includes Tetraplegia and Paraplegia } & $\begin{array}{l}\text { If yes, answer } \\
\text { questions } \\
7 \mathrm{a}-7 \mathrm{c}\end{array}$ & $\begin{array}{l}\text { If no, go to } \\
\text { question } 8\end{array}$ \\
\hline & $7 a$. & $\begin{array}{l}\text { Do you have difficulty controlling your condition with medicstions or ather } \\
\text { physician-prescribed therapies? } \\
\text { (Answer NO if you are net currently taking medications or other teasments) }\end{array}$ & $\square$ & $\square$ \\
\hline & 7b. & $\begin{array}{l}\text { Do you commonly exhibit low resting blood pressure significant enough to cause } \\
\text { daziness, light headedness, and/or fainting? }\end{array}$ & $\square$ & $\square$ \\
\hline & $7 c$ & $\begin{array}{l}\text { Has your physician indicased that you exhibit sudden bouts of high blocd pressure } \\
\text { (known as Autonomic Dysrefleoia?? }\end{array}$ & 口 & $\square$ \\
\hline \multirow[t]{4}{*}{ 8. } & \multicolumn{2}{|c|}{$\begin{array}{l}\text { Have you had a Stroke? } \\
\text { This includes Transient Ischemic Astack (TIA) or Cerebrovascular Event }\end{array}$} & $\begin{array}{l}\text { If yes, answer } \\
\text { questions } \\
\text { 8a-c }\end{array}$ & $\begin{array}{l}\text { If no, } 90 \text { to } \\
\text { question } 9\end{array}$ \\
\hline & Ba. & $\begin{array}{l}\text { Do you have difficulty controlling your condition with medicstions or ather } \\
\text { physidan prescribed therapies? } \\
\text { (Anawer NO if you are not currently taking medications or other treatments) }\end{array}$ & $\square$ & $\square$ \\
\hline & $8 b$. & Do you have any impairment in walking or mobility? & $\square$ & $\square$ \\
\hline & 8c. & $\begin{array}{l}\text { Have you experienced a stroke or impaiment in nerves or muscles in the past } 6 \\
\text { months? }\end{array}$ & $\square$ & 무 \\
\hline \multirow[t]{4}{*}{9.} & \multicolumn{2}{|r|}{$\begin{array}{l}\text { Do you hove any other medical condition not listed above or do you live with two chronic } \\
\text { conditions? }\end{array}$} & $\begin{array}{l}\text { If yes, answer } \\
\text { questions } \\
9 a-5\end{array}$ & $\begin{array}{l}\text { If no, read } \\
\text { the advice } \\
\text { on page } 4\end{array}$ \\
\hline & 9 . & $\begin{array}{l}\text { Have you experienced a blackout, fainted, or lost consciousness as a result of a hesd } \\
\text { injury within the last } 12 \text { monthe OR have you had a diagnosed concussion within the } \\
\text { lest } 12 \text { monshs? }\end{array}$ & $\square$ & $\square$ \\
\hline & \%. & $\begin{array}{l}\text { Do you have a medical condition that is not listed } \\
\text { (such as epilepsy, neurological conditions, kidney problems)? }\end{array}$ & $\square$ & $\square$ \\
\hline & 9 & Do you currently live with two chronic conditions? & $\square$ & $\square$ \\
\hline
\end{tabular}

Please proceed to Page 4 for recommendations for your current medical condition and sign this document. 


\section{EFFECTS OF HIGH-VELOCITY RESISTANCE TRAINING AND CREATINE SUPPLEMENTATION IN UNTRAINED HEALTHY AGING MALE}

\section{PAR-Q+}

If you answered NO to all of the follow-up questions about your medical condition, you are ready to become mere physically active:

IIt is advised that you consult a qualifed exercise profiessional (e.g., a CSEP-CEP or CSEP-CPT) to help you develop a safe and effective physical activity plan to meet your health needs.

, You are encouraged to start slowly and build up gradually $-20-60$ min. of low- to moderate-intensity exercise, 3.5 days per week including aercbic and muscle strengthening exercises.

? As you progress, you should aim to accumulate 150 minutes or more of moderate-intensity physical sctivity per week.

, If you are over the age of $45 \mathrm{yrs}$. and NOT accustomed to regular vigorous physical activity, please consult a qualified exercise professional (CSEP-CEP) before engaging in maximal effort exercise.

If you answered YES to ene or more of the follow-up questions about your medical condition:

, You should seek further information from a licensed health care professional before becoming more physically active or engsging in a fitness appraisal and/or visit a or qualified exercise professional (CSEP-CEP) for further information.

Delay becoming more active if:

, You are not feeling well because of a temporary illness such as a cold or fever - wait until you feel better

, You are pregnant - talk to your heslth care practitioner, your physician, a qualified exercise profesional, and/or complete the PARmed-X for Pregnancy before becoming more physically active OR

, Your health changes - please tak to your doctor or qualifed exercise professional (CSEP-CEP) before continuing with any physical activity programme.

\section{SECTION 3 - DECLARATION}

3. You are encouraged to phosecopy the PAR-Q+. You must use the entire questionnaire and NO changes are permitted.

3. The Canadian Sociey for Exercise Phyaiology, the PAR.Q+ Colaboration, and their agents assume no liablity for persons who undertake physical activity. if in doubt after completing the questionnaire, consul your doctor prior to physical activity.

3 If you are less than the legal age required for consent or require the assent of a care provices, your parent, guardian or care provider must also sign this form

3. Please read and sign the declaration below:

l, the undorsigned, have mad, understood to my full satisfaction and completed this questiannaive. I acknowledge that this physica/ activity cloarance is valid for a maximum of 12 manths from the dute it is completod and becomes invalid if my candition changes. $f$ also acknawibdge that a Trustee (such as my employec, cammunitylitmess centre, heaith care providec, or other designatel may netain a copy of this form for their reconds. In these instances, the Trustee will be recuwired to actheve to local, nationwl, and intemutional guidelines regarding the stcrage of personsl hesith information ensuring that they maintsin the privacy of the informgtion and do not misuse or wrongfilly clisclose such information.

NAME DATE

For more information, please contact: Canadian Society for Exeróse Physiology www.csep.ca

KEY ReFEUENCE

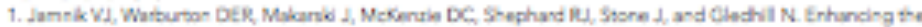

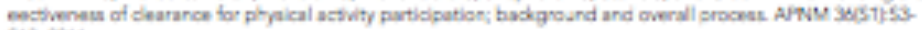
513 2011.

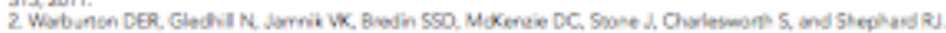

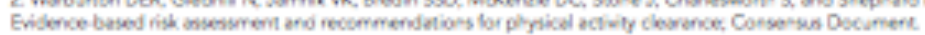

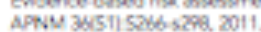

The PAR-Q+ was creased using the evidenotbased AGeLE process (1) by the Mar. Q.Calidbonation daired by Dr. Darren E. R Waburton with Or. Norman Glechal, Or.

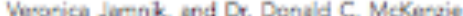

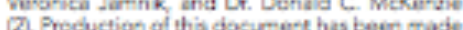
possiole through finoncial conerbutions from poosuce vrough thanca combevors from the Public Heath Agency of Canacla and the BC Ministry of Heath Services. The vens expressed heren do not necessarly represent the views of the Public Health Agancy of Canade ar BC Ministry of Mealth Services. 


\section{EFFECTS OF HIGH-VELOCITY RESISTANCE TRAINING AND CREATINE SUPPLEMENTATION IN UNTRAINED HEALTHY AGING MALE}

The PARimed-X is a physical actlitity-apecific checkllst to be used by a physician with patients who have had positive responses to the Physical Activity Readiness Questionnaire (PAR- $Q$ ). In addition, the Conveyance/Referral Form in the PARmed-X can be used to convey clearance for physical activity participation, or to make a referral to a medically-gupervised exercise program.

Regular physical acsivity is fun and heathy, and increasingly more poople are starting to become more active every diny. Being mate active

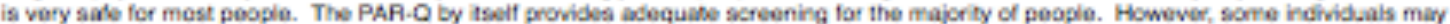
require a medical evaluision and specific asvice (emarcise prescription) due to one or more positive responses to the PAR-O.

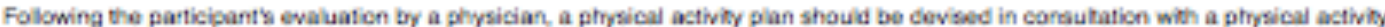

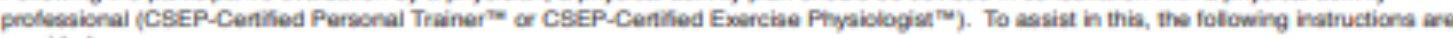
provided:

PAGE 1: - Sections A, B, C, and D should be complesed by the participane BEFORE the examination by the phryician. The bonom section is to be compieted by the examining physician.

PAGES 2 \& 3: . 'A checklat of medical condisons requiring special consideration and managememt.

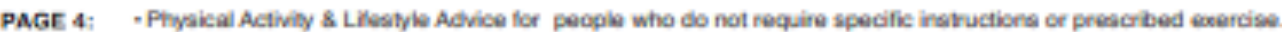

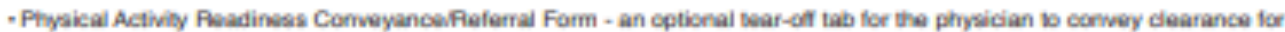
physical sctivity participston, or to maise a referral to a medically-supervibed exercise propram

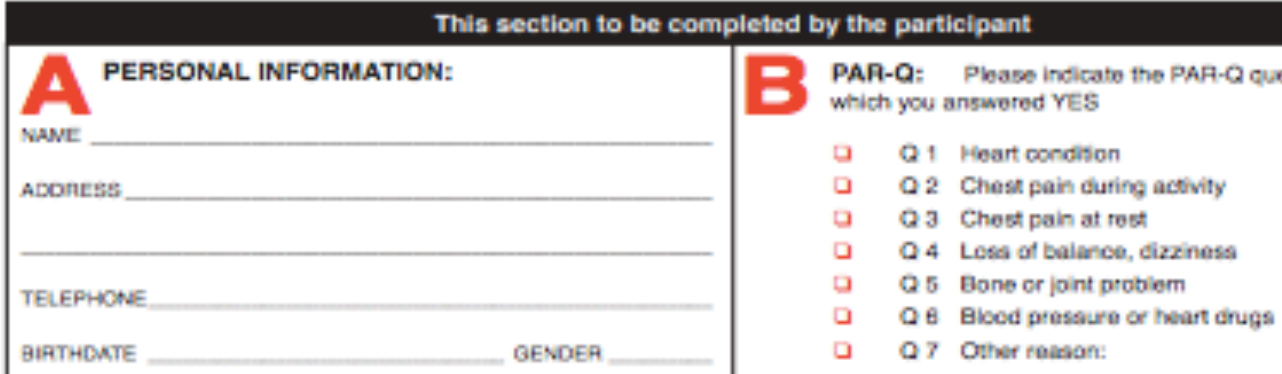

MEDICN NW.

ALSK FACTORS Fon CARDIOVASCULAR DISEASE: Check al that apoly

a Leas than 30 minutes of moderate physical activity mesh days of the wovk.

5 Curtenty smoker (tobscos smoking 1 or mone times per week)

- High blood preasure reponted by physician after repesied messurementis

I Wh cholestenol hevel reported by physicis
D. Excessive accumulation of far around wasen.

Family history of heart disease

Please noce: Lary of mase nisk facters aine modifable. Plwase nofer bo page 4 and dscubs won your physicias.

\section{This section to be completed by the examining physician}

Physical Exam:

\begin{tabular}{|c|c|c|c|}
\hline \multirow[t]{2}{*}{$\mathrm{Ht}$} & \multirow[t]{2}{*}{ wh } & $B P \quad 10$ & I \\
\hline & & BP & 1 \\
\hline
\end{tabular}

Conditions limiting physical activity.

- Cardowascular a Resciratary a Coter

- Muscubakeibtal

abdominal

Tests required:

D ECO

a aioce

ב Exarciae Test

X-Aary

a Urinaysis
Physical Activity Aectiliness Conveyance/peferral:

Based upen a cument review of theath Forver iniometions sacus. I fecommend:

a No physical activity

G afiached

- Only a medicaly-supervised exercies program urbil Arther mecical charance

- Progreseive physical activity

a wh aveidance of.

$\square$ wth inclusion of:

J uncer the supervision of a CSEP.Cartifed Exoncise Phyaidocistro

Unestricted physical sctivity-start slowly and buld up gradually 


\section{EFFECTS OF HIGH-VELOCITY RESISTANCE TRAINING AND CREATINE SUPPLEMENTATION IN UNTRAINED HEALTHY AGING MALE}

Trutea Activity Rnaches Nucical Bominaton

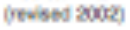

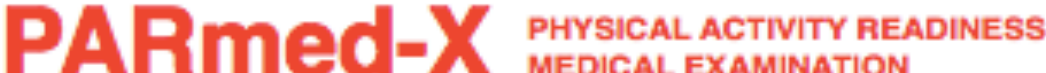

Following is a checkist of medical cenditiona for which a dogree of precauticn andlor spocial advice should be caraiclered for those who anowened "YES" to one or more questions on the PAP-Q and pecple over the ape of 69 . Condions are grouped by syeterm. Three categories of precautions are provided. Comments under Advice ane general. since detsils and alsernattves recuire clinical judgemert in each ind vidusi instance.

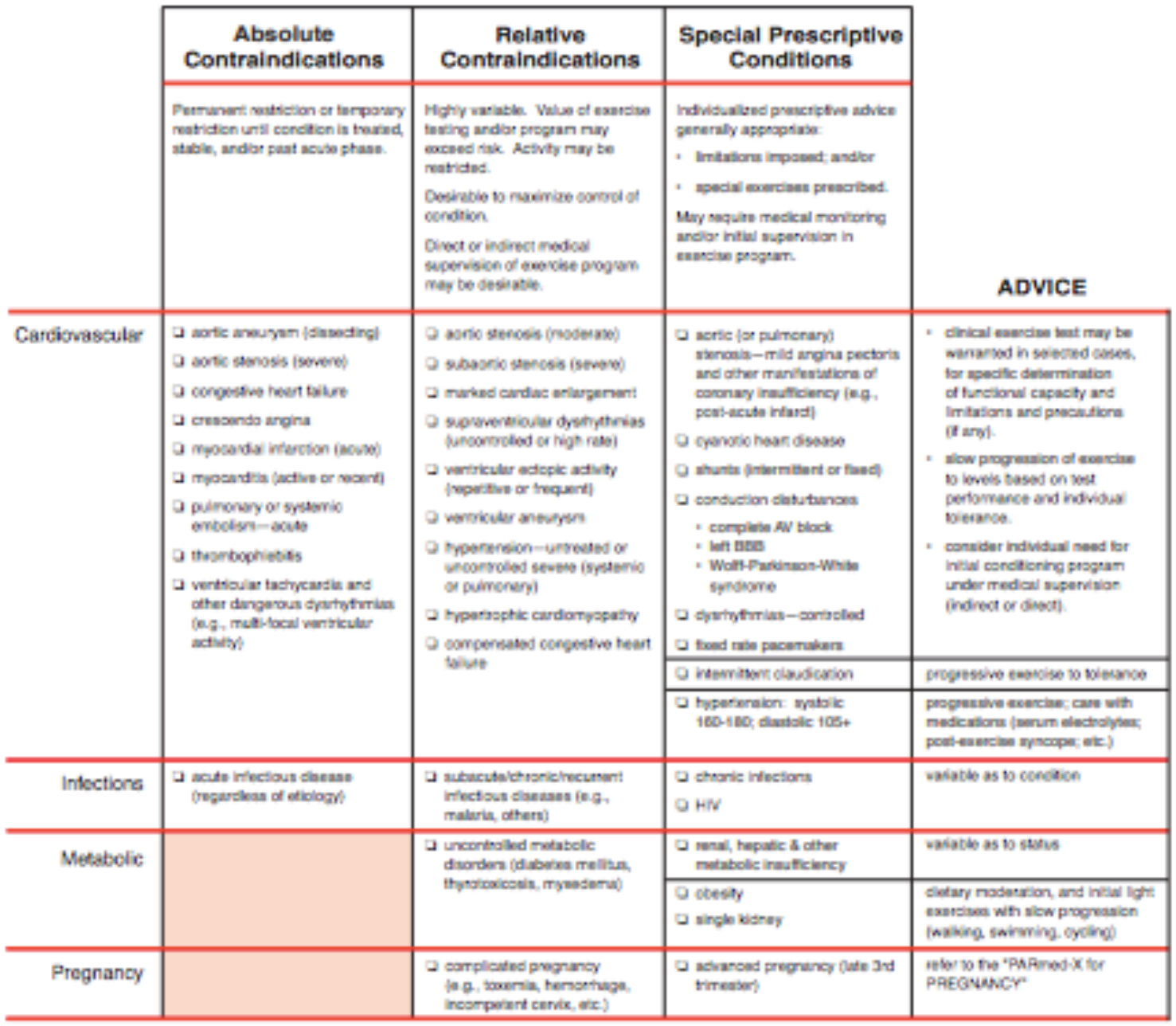

\section{Aeterences:}

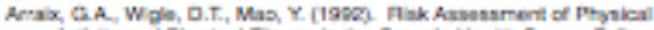

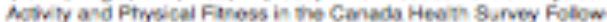

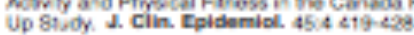

Monoia, M. Woit. LA (1904). Actee Lierg and Fregranck in A. Duiney, L. Gauvin, T. Wall (acks, Toward Active Luving: Proscasings of the International Conforente an Phyaleal

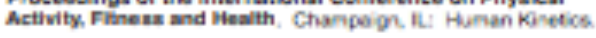

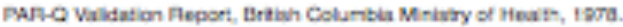

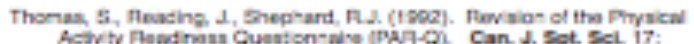
Activty Hoad
The PAA- $Q$ and PAPred- $X$ were developed by the Brish Columba Minietry of Health. They have been revised by an Expert Advioory Commitee of the Caradian Society for Exarcise Physiology chaired by Dr. N. Glednil (200Z)

\section{No changes permitted. You are encouraged to} photocopy the PARmed $\mathbf{X}$, but only if you use the entire form.

Disponbie en français socus le tere -Evaluation medicsie de l'aptbude sa lactivite physique (X-AAP/- 


\section{EFFECTS OF HIGH-VELOCITY RESISTANCE TRAINING AND CREATINE SUPPLEMENTATION IN UNTRAINED HEALTHY AGING MALE}

\begin{tabular}{|c|c|c|c|}
\hline & \multicolumn{2}{|c|}{$\begin{array}{l}\text { Special Prescriptive } \\
\text { Conditions }\end{array}$} & ADVICE \\
\hline \multirow[t]{3}{*}{ turg } & \multicolumn{2}{|c|}{ D dhonic pulnorary dacriben } & 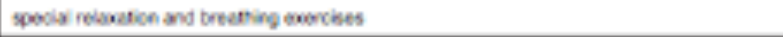 \\
\hline & \multicolumn{2}{|c|}{ 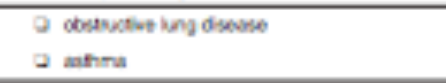 } & 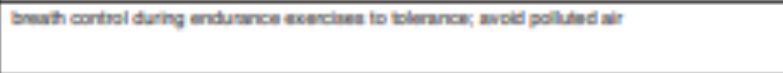 \\
\hline & \multicolumn{2}{|c|}{ O teovise indoced thonchospess? } & 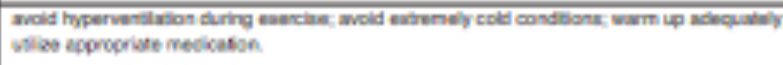 \\
\hline \multirow[t]{7}{*}{ Muscakrakeletal } & \multicolumn{2}{|c|}{ O kw back condions batwoiojica. Ancticral? } & 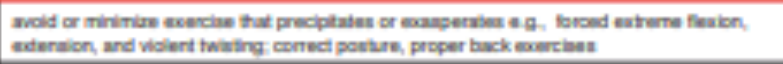 \\
\hline & \multicolumn{2}{|c|}{ 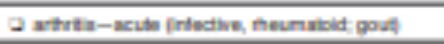 } & 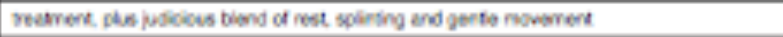 \\
\hline & \multicolumn{2}{|c|}{ Q arivis-sucacsw } & 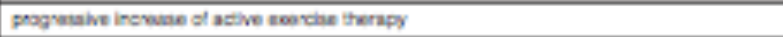 \\
\hline & \multicolumn{2}{|c|}{ 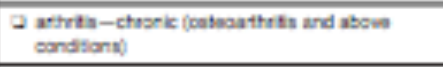 } & 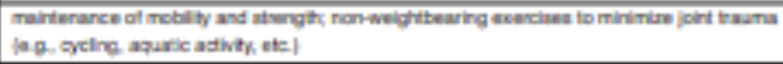 \\
\hline & \multicolumn{2}{|l|}{ O orinopowio } & Niphly weriabie and individuigen \\
\hline & \multicolumn{2}{|l|}{ O nemia } & 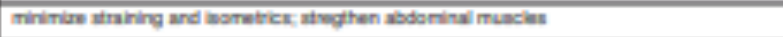 \\
\hline & \multicolumn{2}{|c|}{ D ariscportain or low bone deraity } & 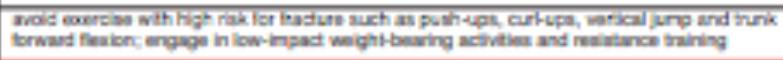 \\
\hline \multirow[t]{2}{*}{ CN5 } & \multicolumn{2}{|c|}{ 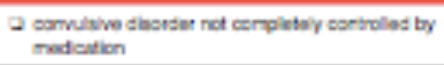 } & 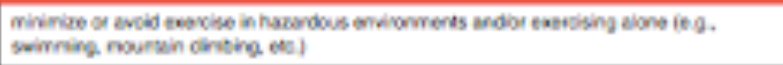 \\
\hline & \multicolumn{2}{|l|}{ O nowe concussion } & 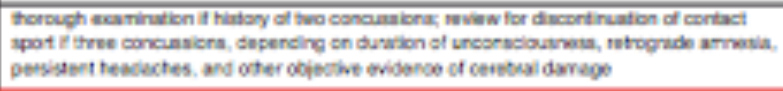 \\
\hline Blood & \multicolumn{2}{|c|}{ 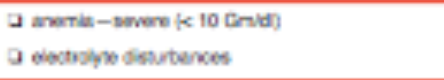 } & control preterned: conctas an folenated \\
\hline Medications & 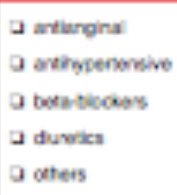 & 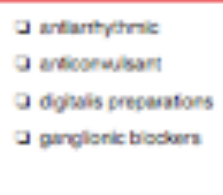 & 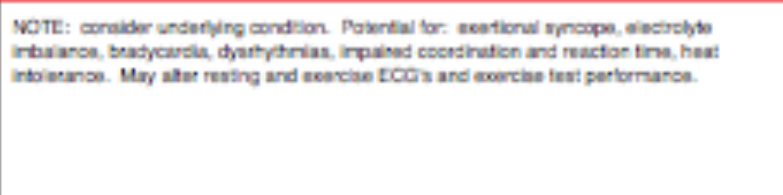 \\
\hline \multirow[t]{4}{*}{ Other } & \multicolumn{2}{|c|}{ O posicunoise syoope } & rodenats propurn \\
\hline & \multicolumn{2}{|l|}{ D hat irtsierance } & 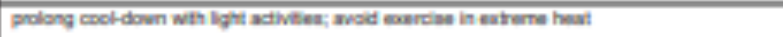 \\
\hline & \multicolumn{2}{|c|}{ O wencoury rinor keess } & Dostoone ves recouted \\
\hline & \multicolumn{2}{|l|}{ Denoer } & 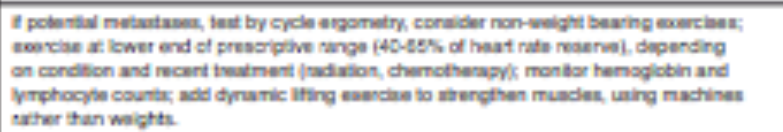 \\
\hline
\end{tabular}

- Fobler to spes al pstications for abboration as repuked

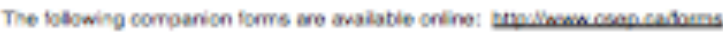

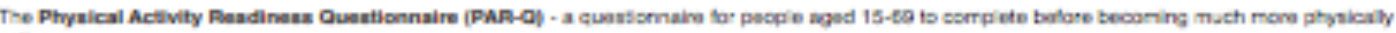
active.

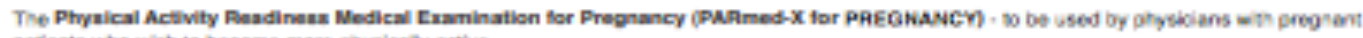
pesierts who wish 10 teoone more prysioaly ective.

For more ibomation. please cortact vie:

Note to physical activity professionals..

It is a prudent prastice to retain the completed Physical Activity Reacineas Conveyance/Relerral Form in the participarts file.

\section{CSEP ISCPE}

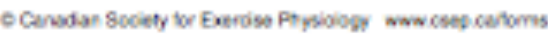


Westal Aativity Hackeres

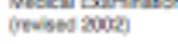

PARmed-X X

g.m.

PARmed-X Physical Activity Readiness Conveyance/Referral Form

Based upon a currert roview of the heath status of

- No physical activity

- Only a medicaly-supervised exencise program urbi further medieal cloarance

口 Progressive phryical activity

a with arroiclance of.

with inclusion ot

a under the supervision of a CSEP-Certifed Exarciae Phyaiologish ${ }^{\text {a }}$

- Unestricted physical activty - Gart slowly and buld up gradially
I recommend.

Nurther inforrmaden

O Anacheod

(5) To be sowionded

a. Avwiluble an nocuent
Phytioandirio otano:

4 


\section{Appendix B: Godin Leisure-Time Questionnaire}

\section{Godin Leisure-Time Exercise Questionnaire}

1. During a typical 7-Day period (a week), how many times on the average do you do the following kinds of exercise for more than 15 minutes during your free time (write on each line the appropriate number).

Times Per

Week

a) STRENUOUS EXERCISE

(HEART BEATS RAPIDLY)

(e.g., running, jogging, hockey, football, soccer, squash, basketball, cross country skiing, judo, roller skating, vigorous swimming.

vigorous long clistance bicycling)

b) MODERATE EXERCISE (NOT EXHAUSTING)

(e.g., fast walking, baseball, tennis, easy bicycling. voleyball, badminton, easy swimming, alpine sking. popular and folk dancing)

c) MILD EXERCISE (MINIMAL EFFORT)

(e.g., yoga, archery, fishing from river bark, bowling. horseshoes, golf, snow-mobiling, easy walking)

2. During a typical 7-Day period (a week), in your leisure time, how often do you engage in any regular activity long enough to work up a sweat (heart beats rapicly)?

$\begin{array}{lll}\text { OFTEN } & \text { SOMETIMES } & \text { NEVER/RARELY } \\ \text { 1. } & \text { 2. } & \text { 3. }\end{array}$




\section{Appendix C: Consent Form}

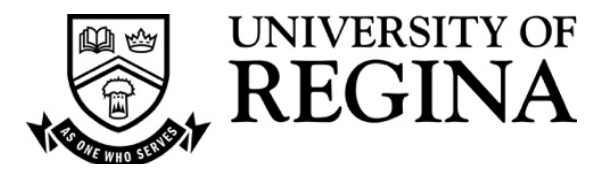

\section{Research Participant Information and Consent Form}

Title of the study: The effects of high-velocity resistance training and creatine supplementation in healthy aging males.

Researchers: Darren G. Candow, Ph.D. (Principal Investigator), Faculty of Kinesiology and Health Studies, University of Regina, phone: 306-585-4906, email:

Darren.Candow@uregina.ca; Patrick Bernat, MSc student researcher, email:

Patrick.Bernat@uregina.ca

24-hour emergency telephone contact: $306-209-0280$

\section{Introduction:}

You are being invited to participate in this research study because we are interested in determining the effects of high-velocity resistance training and creatine supplementation on muscle thickness, muscle performance, and functionality.

Before you decide to participate, it is important that you understand what the research involves. This consent form will tell you about the study, why the research is being performed, what will happen to you during the study, and the possible benefits, risks, and discomforts.

If you wish to participate, you will be asked to sign this form. Your participation is completely voluntary, so it is up to you to decide whether or not to participate in this study. If you decide to take part in this study, you are free to withdraw at any time without giving any reasons for your decision and your choice not to participate will not affect your relationship with any of the researchers or institutions conducting the research. Please take time to read the following information carefully and feel free to discuss it with your family, friends, and doctor or health professional before you decide.

\section{Why is this study being done?}

The purpose of the study is to compare the effects of high-velocity resistance training and creatine supplementation to high-velocity resistance training and placebo on muscle thickness, muscle performance, and tasks of functionality. Creatine is a nitrogencontaining compound naturally produced in the body and found in red meat and seafood, and when given in higher amounts than usually consumed in the diet, may increase muscle thickness and muscle performance. A total of 40 participants will be involved in this study.

\section{Who can participate in this study?}

You can participate if you have not engaged in supervised resistance training for $\geq 6$ weeks prior to the start of the study. In addition, you cannot have pre-existing kidney or 
liver problems; taken medications that affect muscle biology or creatine monohydrate $\leq$ 12 weeks prior to the start of the study; have a history of fragility fractures; diseases that are known to affect muscle biology; suffer from severe osteoarthritis; are vegetarian or planning to travel during the study period for greater than two weeks duration at a time.

\section{What does the study involve?}

If you agree to participate in this study, the following will occur:

You will initially be given a questionnaire (Physical Activity Readiness Questionnaire) which assesses whether you are at a health risk for participating in exercise training. If you indicate a possible health risk, you will be given a clearance form (PARMED-X) to be filled out by your family physician before being permitted to participate in this study.

Prior to the start of the study, you will be randomized (i.e. assigned by chance by a computer) into one of two groups: Group 1 will receive creatine monohydrate $(0.1$ grams per kg body weight per day of creatine) during 8 weeks of high-velocity resistance training. Group 2 will receive placebo ( 0.1 grams per kg body weight per day of cornstarch maltodextrin) during 8 weeks of high-velocity resistance training. High-velocity resistance training is defined as lifting the weight as fast as possible (concentric phase) and taking two seconds to lower the weight back to the starting position. The weight you will be lifting will be $80 \%$ of your one-repetition max (1RM; the maximum weight that can be successfully lifted one time with proper form). Creatine and placebo will be in powder form and you will be asked to consume this mixed with water. On days when you are exercising (two days per week), your daily dose will be taken after ( $<5$ minutes) you exercise. On the days where you are not scheduled to exercise, you will consume your daily amount at your leisure. Neither you nor the researchers will know which group you are in until the end of the study, but we can find out what group you are in if there is an emergency (i.e. an adverse reaction to the creatine or placebo).

Both groups will participate in 8 weeks of high-velocity resistance training. Resistance exercises (leg press, leg curl, leg extension, chest press, biceps curl, and triceps extension) will be performed in the Aging Muscle and Bone Health Lab at the University of Regina and will take approximately 60 minutes to complete. Two weeks prior to the start of the study, you will be shown how to use the resistance training equipment with proper form and technique and you will participate in three sessions of training to get accustomed to the exercises. Supplementation with creatine or placebo will begin on the first day of the study (after the three familiarization sessions of the resistance training equipment) and occur daily for the remainder of the study. During these sessions you will perform the 6 resistance training exercises. A warm-up (e.g., stretching and 5 minutes of stationary cycling exercise) will be part of the training session and the resistance used will not increase throughout the study period, only the number of repetitions performed at 80\% 1-RM will increase.

Although $100 \%$ compliance to the exercise program is the expectation, it is unlikely that all participants will meet this goal. Our hope is that you will be able to attend approximately $90 \%$ of the sessions (i.e. 14/16 sessions). You are not expected to attend the training sessions on holidays. You are allowed to do other exercises outside of our program if you choose. 


\section{Study measurements:}

The following measurements will be performed prior to the intervention (i.e. baseline) and after 8 weeks:

- Your muscle thickness will be determined using an ultrasound machine on the right side of your body for the elbow flexors (biceps), elbow extensors (triceps), knee flexors (hamstrings), and knee extensors (quadriceps). This procedure will take approximately 20 minutes.

- Your muscular strength will be determined for each exercise of the high-velocity resistance training program (leg press, leg curl, leg extension, chest press, biceps curl, and triceps extension). This procedure will take approximately 30 minutes.

- Your muscle power will determined for the right knee extensors (quadriceps) and knee flexors (hamstrings) using an isokinetic dynamometer. This procedure will take approximately 10 minutes.

- Balance will be determined by walking backwards toe-to-heel on a board that is $5 \mathrm{~cm}$ above the ground for 6 meters. This test will be repeated twice. We will measure the time it takes you to do this test and the number of times you step off the board. Walking speed will be assessed by the time required to walk an 80 meter course as fast as possible. This procedure will take approximately 10 minutes.

\section{What are the benefits of participating in this study?}

You might increase your muscle thickness, power, strength, balance and walking speed by participating in this study. These benefits are not guaranteed.

\section{What are the possible risks and discomforts?}

The resistance training and strength testing may result in minor muscle pulls and strains. You will be given proper warm-up prior to exercising and be supervised by an exercise professional and this will minimize the risk. Adequate rest will be given between training and testing sessions to ensure that your muscles are recovered by the next training session.

Creatine supplementation has been shown on a few occasions to decrease kidney and liver function in individuals with pre-existing kidney or liver disease. If you have any kidney or liver abnormalities, you should not participate in this study.

\section{What are alternatives to the study?}

You do not have to participate in this study to have your body composition assessed. You could have your body composition determined through an appointment with the Dr. Paul Schwann Center, Faculty of Kinesiology and Health Studies at the University of Regina and this can be performed by a number of different techniques (i.e. skin folds, bioelectrical impedance analysis). You do not have to participate in this study to increase muscle performance or balance. You can perform alternative exercises (i.e. free-body 
exercises such as push-ups and wall squats instead of the resistance exercises in this study). You could also increase your creatine consumption from your diet by consuming more red meat and seafood products instead of receiving creatine supplementation in this study.

\section{What happens if I decide to withdraw?}

Your participation in this research is voluntary. You may withdraw from this study at any time. You do not have to provide a reason. Your relationships with the researchers or the university will not be affected. If you choose to enter the study and then decide to withdraw at a later time, all data collected about you during your enrolment will be retained for analysis.

\section{What happens if something goes wrong?}

In the case of a medical emergency related to the study, you should seek immediate care and, as soon as possible, notify the principal investigator. Inform the medical staff you are participating in a clinical study. Necessary medical treatment will be made available at no cost to you. By signing this document, you do not waive any of your legal rights against the sponsor, investigators or anyone else.

\section{What happens after completion of the study?}

We will inform you of the overall study results after we have analyzed all data.

\section{What will the study cost me?}

You will not be charged for the creatine, placebo, or any research-related procedures. You will not be paid for participating in this study. Reimbursement for study-related expenses (e.g. travel, parking, meals) is not available.

\section{Will my participation be kept confidential?}

In Saskatchewan, the Health Information Protection Act (HIPA) defines how the privacy of your personal health information must be maintained so that your privacy will be respected. Your name will not be attached to any information, nor mentioned in any study report, nor be made available to anyone except the research team. It is the intention of the research team to publish results of this research in scientific journals and to present the findings at related conferences and workshops, but your identity will not be revealed.

\section{Who do I contact if I have questions about the study?}

If you have questions concerning the study you can contact Dr. Darren Candow at 306$585-4906$ or 306-209-0280 (24 hour cell).

If you have any questions about your rights as a research subject or concerns about this study, you may contact the Chair of the University of Regina Research Ethics Board at (306) 585-4775 or email research.ethics@uregina.ca. Out of town participants may call collect.

\section{Consent statement}

- I have read (or someone has read to me) the information in this consent form. 
I I understand the purpose and procedures and the possible risks and benefits of the study.

I I have been informed of the alternatives to the study.

- I was given sufficient time to think about it.

- I had the opportunity to ask questions and have received satisfactory answers.

- I am free to withdraw from this study at any time for any reason and the decision to stop taking part will not affect my future relationships at the university.

- I agree to follow the principal investigator's instructions and will tell the principal investigator at once if I feel I have had any unexpected or unusual symptoms.

- I have been informed there is no guarantee that this study will provide any benefits to me.

- I give permission for the use and disclosure of my de-identified personal health information collected for the research purposes described in this form.

- I understand that by signing this document I do not waive any of my legal rights.

$\circ \quad$ I will be given a signed and dated copy of this consent form.

- I give permission for my family physician to be informed about my participation in this study if need be:

$\square$ Yes

$\square$ No

$\square$ I do not have a family physician

I agree to participate in this study:

Printed name of participant:

Signature

Date

Printed name of person obtaining consent:

Signature

Date 


\section{Appendix D: Resistance Training Log}

\begin{tabular}{|c|c|c|c|c|c|}
\hline \multicolumn{6}{|l|}{ Participant Name: } \\
\hline Familiarization 1 of 3 & \multirow[t]{2}{*}{ Machine Settings } & \multirow{2}{*}{$\begin{array}{c}\text { Weight ( } 80 \% \\
\text { 1RM) }\end{array}$} & \multirow[t]{2}{*}{ Sets } & \multirow[t]{2}{*}{ Reps } & \multirow[t]{2}{*}{ Notes } \\
\hline Exercise: & & & & & \\
\hline Bilateral Leg press & & & 2 & & \\
\hline Leg Extension & & & 2 & & \\
\hline Leg Curl & & & 2 & & \\
\hline Chest Press & & & 2 & & \\
\hline Triceps Extension & & & 2 & & \\
\hline Biceps Curl & & & 2 & & \\
\hline Familiarization 2 of 3 & \multirow[t]{2}{*}{ Machine Settings } & \multirow{2}{*}{$\begin{array}{c}\text { Weight }(80 \% \\
\text { 1RM) }\end{array}$} & \multirow[t]{2}{*}{ Sets } & \multirow[t]{2}{*}{ Reps } & \multirow[t]{2}{*}{ Notes } \\
\hline Exercise: & & & & & \\
\hline Bilateral Leg press & & & 3 & & \\
\hline Leg Extension & & & 3 & & \\
\hline Leg Curl & & & 3 & & \\
\hline Chest Press & & & 3 & & \\
\hline Triceps Extension & & & 3 & & \\
\hline Biceps Curl & & & 3 & & \\
\hline Familiarization 3 of 3 & \multirow[t]{2}{*}{ Machine Settings } & \multirow{2}{*}{$\begin{array}{c}\text { Weight ( } 80 \% \\
\text { 1RM) }\end{array}$} & \multirow[t]{2}{*}{ Sets } & \multirow[t]{2}{*}{ Reps } & \multirow[t]{2}{*}{ Notes } \\
\hline Exercise: & & & & & \\
\hline Bilateral Leg press & & & 4 & & \\
\hline Leg Extension & & & 4 & & \\
\hline Leg Curl & & & 4 & & \\
\hline Chest Press & & & 3 & & \\
\hline Triceps Extension & & & 3 & & \\
\hline Biceps Curl & & & 3 & & \\
\hline
\end{tabular}




\begin{tabular}{|c|c|c|c|c|c|}
\hline \multicolumn{6}{|l|}{ Participant Name: } \\
\hline Session 1 of 16 & \multirow[t]{2}{*}{ Machine Settings } & \multirow{2}{*}{$\begin{array}{c}\text { Weight (80\% } \\
\text { 1RM) }\end{array}$} & \multirow[t]{2}{*}{ Sets } & \multirow[t]{2}{*}{ Reps } & \multirow[t]{2}{*}{ Notes } \\
\hline Exercise: & & & & & \\
\hline Bilateral Leg press & & & 4 & & \\
\hline Leg Extension & & & 4 & & \\
\hline Leg Curl & & & 4 & & \\
\hline Chest Press & & & 3 & & \\
\hline Triceps Extension & & & 3 & & \\
\hline Biceps Curl & & & 3 & & \\
\hline Session 2 of 16 & \multirow[t]{2}{*}{ Machine Settings } & \multirow{2}{*}{$\begin{array}{l}\text { Weight ( } 80 \% \\
\text { 1RM) }\end{array}$} & \multirow[t]{2}{*}{ Sets } & \multirow[t]{2}{*}{ Reps } & \multirow[t]{2}{*}{ Notes } \\
\hline Exercise: & & & & & \\
\hline Bilateral Leg press & & & 4 & & \\
\hline Leg Extension & & & 4 & & \\
\hline Leg Curl & & & 4 & & \\
\hline Chest Press & & & 3 & & \\
\hline Triceps Extension & & & 3 & & \\
\hline Biceps Curl & & & 3 & & \\
\hline Session 3 of 16 & \multirow[t]{2}{*}{ Machine Settings } & \multirow{2}{*}{$\begin{array}{c}\text { Weight }(80 \% \\
\text { 1RM) }\end{array}$} & \multirow[t]{2}{*}{ Sets } & \multirow[t]{2}{*}{ Reps } & \multirow[t]{2}{*}{ Notes } \\
\hline Exercise: & & & & & \\
\hline Bilateral Leg press & & & 4 & & \\
\hline Leg Extension & & & 4 & & \\
\hline Leg Curl & & & 4 & & \\
\hline Chest Press & & & 3 & & \\
\hline Triceps Extension & & & 3 & & \\
\hline Biceps Curl & & & 3 & & \\
\hline
\end{tabular}



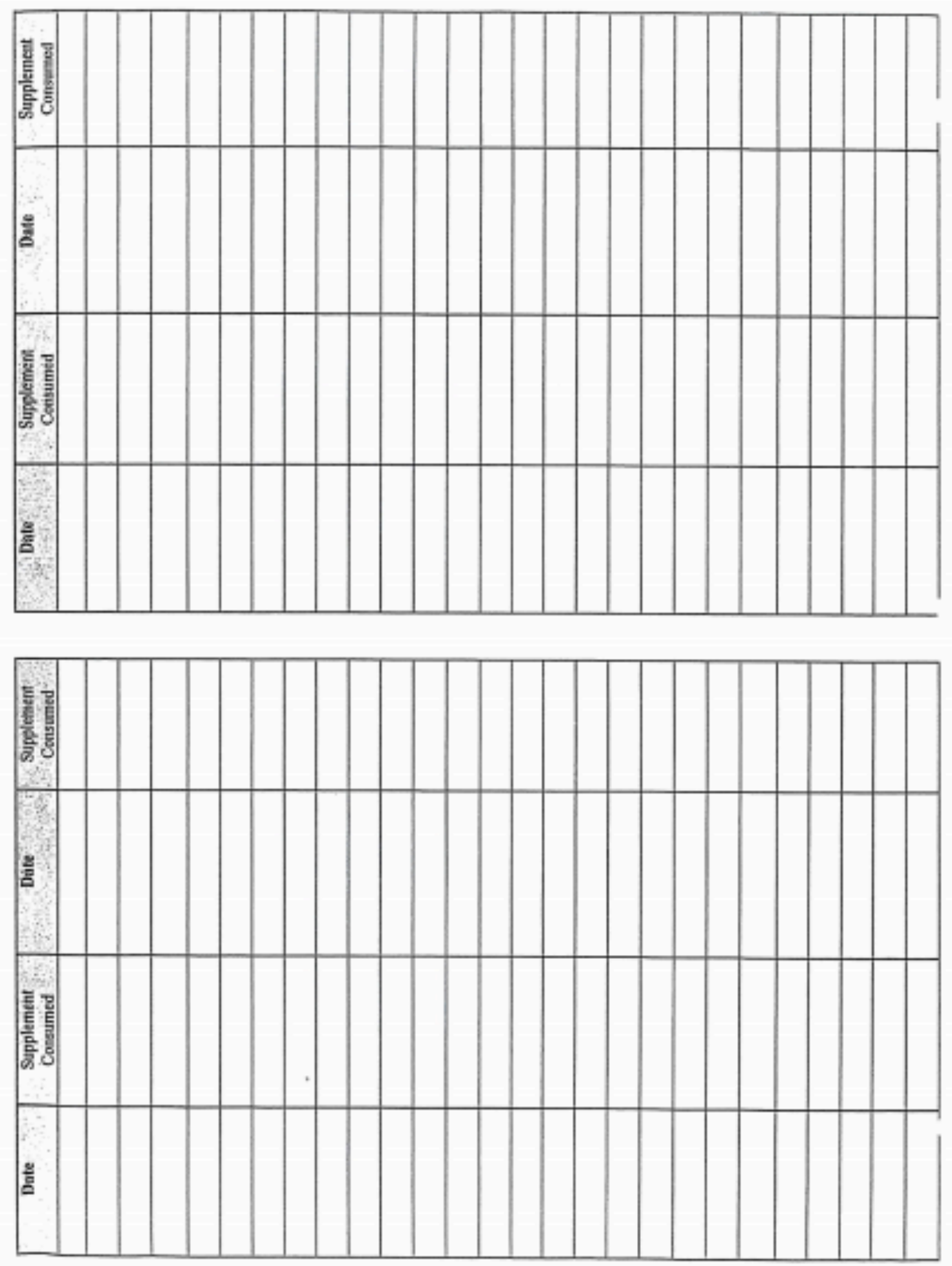


\title{
EFFECTS OF HIGH-VELOCITY RESISTANCE TRAINING AND CREATINE SUPPLEMENTATION IN UNTRAINED HEALTHY AGING MALE
}

\author{
Appendix F: 3-Day Food Log
}

\section{3-Day Food Intake Record}

Please keep a record of everything you EAT and DRINK for 3 days -2 weekdays and 1 weekend day. Include all meals, snacks, and beverages, and the time of day you are eating or drinking. Please pick days that are TYPICAL for your current eating patterns.

Please also record the supplements (i.e. vitamins, minerals, protein powders, sport supplements, shakes, etc.) in detail, including: the name or supplement, the amount you take, how often you take it, when you started the supplement, and your reason for taking it.

The purpose of filling out these food records is to help better understand WHAT you are eating. WHEN you are eating, and HOW MUCH you are eating. Please be as honest and accurate as you can, as the information you provide will help you better reflect on your eating habits.

\section{FOOD/BEVERAGE RECORDING INSTRUCTIONS:}

1. Record all food and beverages consumed during a 24 hour period. Provide the following:

- Type of Food Eaten: e.g. chicken noodle soup

* Brand Name: e.g. Campbell's, Lipton, Weight Watchers

- Food or Beverage Characteristics:

- Colour: e.g. green vs, yellow beans; white vs. whole wheat bread

- Fat Content: $\%$ fat (e.E. skim, 1\%, $2 \%$ or homo milk), leanness of meat (e.g. extra lean ground beef), fat claims (e.g. "light", "low-fat"), was skin removed from poultry?

- Freshness: e.g. fresh, frozen, canned, or dried?

- Other Details: e.8. $25 \%$ reduced sodium, "diet" products, etc.

- Time of Day you ate or drank

2. Please MEASURE and describe the amount of food eaten as best as possible. Diet records are only reliable with accurate measurements.

- Always estimate portion slzes of food after cooking.

- Use household measures to specify serving sizes.

$$
\begin{array}{ll}
1 \text { cup }=250 \mathrm{~mL}=8 \text { fluid oz } & 1 \text { tablespoon (Tbsp] }=15 \mathrm{~mL} \\
1 \text { ounce }(o z)=30 \mathrm{~g} & 1 \text { teaspoon }[\mathrm{tsp})=5 \mathrm{~mL}
\end{array}
$$

- Measuring cups (examples): Put cooked pasta or rice into a measuring cup to record the correct amount before placing it on your plate. Measure your cereal out before pouring into a bowl, and don't forget to measure your milk as well!

- Teaspoons/tablespoons (examples): Measure out butter, margarine, mayonnaise, salad dressings, ketchup, mustard, ground flaxseed, sugar, milk/cream, and other condiments, seasonings, and toppings before adding to your food or beverages.

- Count the number of food items if practical: e.g.: 20 grapes, 15 baby carrots, 8 medium-sized shrimp, etc.

- Fluids: Record amounts in fluid ounces (oz), milliliters (mL), or in cups., Remember 1 cup $=250 \mathrm{~mL}=8$ fl. 02 
- Use food labels to estimate quantities: Food labels can help you estimate the quantity of food eaten based on weight or volume. For example, write down a $355 \mathrm{~mL}$ can of pop, $1 / 2$ of a $60 \mathrm{~g}$ can of tuna, a $37 \mathrm{~g}$ granola bar, etc.

- Use your hand to estimate portion sizes quickly:
Whole Thumb $=1$ Tablespoon
Tip of your Thumb = 1 Teaspoon
Palm of Your Hand $=3 \mathrm{oz}$ of meat
Fist $=1 \operatorname{cup}(250 \mathrm{~mL})$

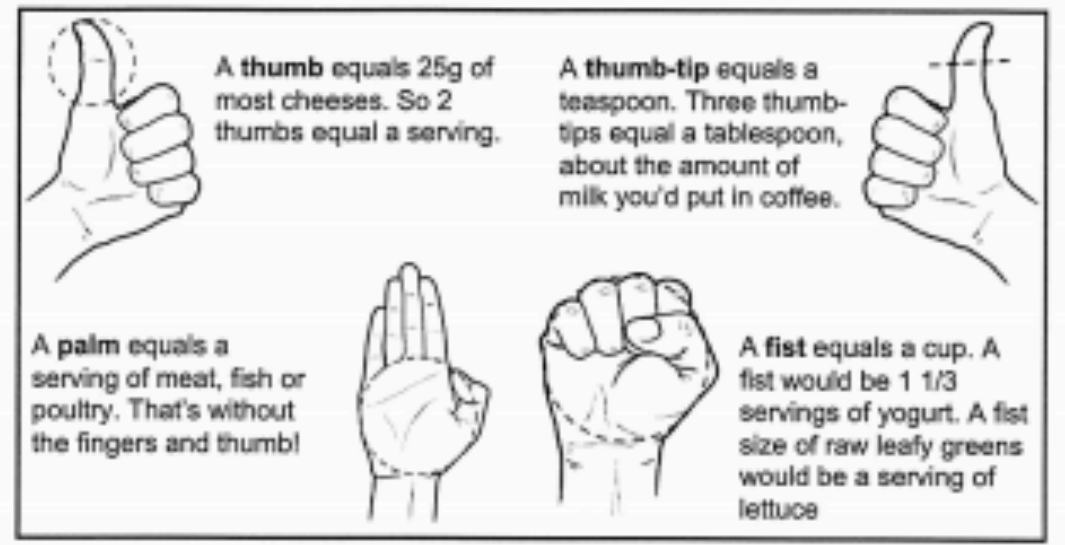

3. Record if anything was ADDED when preparing the food, such as oil (list specific kind), sauce, butter, margarine, or other condiments or seasonings.

4. For COMBINATION DISHES such as lasagna, casseroles, chill, soups, or stews include a description of the main ingredients. E. $g$. Lasagna: lean ground beef ( $1 / 4$ cup per piece), mozzarella cheese ( 1 oz per piece), cottage cheese ( 1 oz per piece), $1 / 2$ cup tomato sauce, 2 noodles, $1 / 4$ cup spinach.

5. Include SNACK FOODS eaten. Don't forget to include candy, chips, cookies, popcorn, ice cream, and beverages such as soft drinks, juice, coffee, or tea.

6. Use the "notes" column to record any additional PRODUCT INFORMATION if available (e.E. 6 crackers -80 calories, $2.5 \mathrm{~g}$ fat, $1 \mathrm{~g}$ fibre, $210 \mathrm{mg}$ sodium).

7. Don't forget to write down any ALCOHOUC BEVERAGES consumed and how much you drank. This includes all wine, beer, and liquor.

\section{When in doubt... include more details!}




\section{Appendix F: 3-Day Food Log}

\section{Sample 1-Day Food Record}

Below is an EXAMPLE of how to keep accurate records. Include a detailed description and amounts for each item. Remember to record water, notes on product details, and the times of day you ate.

\begin{tabular}{|c|c|c|c|}
\hline TIME & AMOUNT & DESCRIPTION & NOTES \\
\hline \multirow[t]{3}{*}{$8 a m$} & Large & Coffee & Tim Horton's \\
\hline & 1 Thsp & Cream & \\
\hline & $2 \mathrm{tsp}$ & Sugar & \\
\hline \multirow[t]{5}{*}{11 am } & 2 slices & Bread, whole wheat & \\
\hline & $2 \mathrm{oz}$. & Turkey, lunchmeat & Oven-roasted from deli \\
\hline & 1 Tbsp & Mayo (Hellman's) & "light", $4.5 \mathrm{~g}$ fat per Tbsp \\
\hline & 1 leaf & Romaine Lettuce & \\
\hline & $1 \mathrm{tsp}$ & Becel Margarine & Salt-free \\
\hline 11:30pm & 2 cups & Water, tap & \\
\hline \multirow[t]{3}{*}{$2 \mathrm{pm}$} & 1 medium & Apply (granny smith) & \\
\hline & 6 & Whole wheat crackers (Premium Plus) & $\begin{array}{l}80 \text { cals, } 2.5 \mathrm{~g} \text { fat, } 210 \mathrm{mg} \\
\text { sodium (from label) }\end{array}$ \\
\hline & $1^{\prime \prime} \times 1^{\prime \prime}$ cube & Marble cheese, 35\% MF & Crackerbarrel \\
\hline \multirow[t]{2}{*}{$4 \mathrm{pm}$} & 1 large & Muffin, blueberry & Store-bought \\
\hline & $500 \mathrm{~mL}$ & Water, tap & \\
\hline \multirow[t]{7}{*}{ 7:30pm } & 1 patty & Hamburger, BBQ'd (regular ground beef) & M\&M Meat Shops ( $\left.{ }^{\sim} 40 z.\right]$ \\
\hline & 1 & Hamburger Bun, white bread & \\
\hline & 1 leaf & Iceburg Lettuce & \\
\hline & 2 slices & Tomato, raw & \\
\hline & 1 slice & Red Onion, raw & \\
\hline & 2 Tbsp & Ketchup, Heinz & 45 calories per tsp \\
\hline & 1 bottle & Beer (12 oz, $5 \%$ alcohol) & Moosehead \\
\hline $10 \mathrm{pm}$ & 2 cups & Chocolate ice cream & Chapman's \\
\hline
\end{tabular}

Was this a typical day? If not, why? Usually drink more water (forgot water bottle at homel Did you take all of your usual medications and supplements as prescribed? $\square$ Yes $\square$ No 


\section{DAILY FOOD RECORD}

Subject Code: Date:

Weekday or

Weekend

Please list all food/beverages/water/medications/supplements. Estimate all food/drink amounts accurately.

\begin{tabular}{|c|c|c|c|}
\hline TIME & AMOUNT & DESCRIPTION & NOTES \\
\hline & & & \\
\hline & & & \\
\hline & & & \\
\hline & & & \\
\hline & & & \\
\hline & & & \\
\hline & & & \\
\hline & & & \\
\hline & & & \\
\hline & & & \\
\hline & & & \\
\hline & & & \\
\hline & & & \\
\hline & & & \\
\hline & & & \\
\hline & & & \\
\hline & & & \\
\hline & & & \\
\hline & & & \\
\hline & & & \\
\hline & & & \\
\hline & & & \\
\hline & & & \\
\hline & & & \\
\hline & & & \\
\hline & & & \\
\hline
\end{tabular}

Was this a typical day? If not, why?

Did you take all of your usual medications and supplements as prescribed? $\square$ Yes $\square$ No 
Appendix G: Study Adverse Event From

Study Adverse Event Form

THE EFFECTS OF HIGH-VELOCITY RESISTANCE TRAINING AND CREATINE SUPPLEMENTATION IN HEALTHY AGING MALES

Participant ID \#:

Participant Initials:

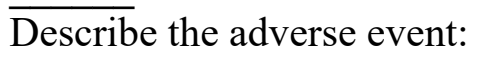

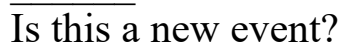

Is this a change/resolution of an ongoing event?

Onset of Adverse Event (date/time):

Resolution of Adverse Event (date/time):

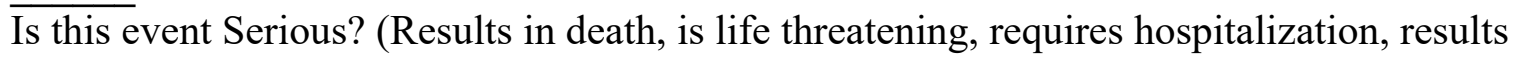
is persistent or significant disability)

No $\square$

Is this event intermittent?

Yes $\square$

No $\square$

1. Rate Intensity (severity)

Mild Moderate Severe Life-threatening

Different levels of intensity are defined as follows:

- Mild: awareness of sign or symptom, but easily tolerated

- Moderate: discomfort enough to cause interferences with normal daily activities

- Severe: Inability to perform normal daily activities

- Life-threatening: Immediate risk of death from the reaction as it occurred

2. Is the adverse event still present? 
3. Frequency:

4. Relationship to experimental procedure (food, exercise or other procedure): Please circle one

Not related Unlikely Possible Probable Definite

Relationship to the supplement, exercise training, or other procedure:

- Not related: An adverse event which is not related to the study

- Unlikely: An adverse event for which an alternative explanation is more likely

- Possible: An adverse event which might be due to the study. An alternative explanation is inconclusive. The relationship in time is reasonable; therefore, the casual relationship cannot be excluded.

- Probable: An adverse event which might be due to the study. The relationship in time is suggestive (i.e. confirmed by dechallenge of the treatment). An alternative explanation is less likely.

- Definite: An adverse event which cannot be reasonably explained by alternative explanation. The relationship is very suggestive (e.g. it is confirmed by dechallenge and rechallenge).

Was treatment administered?

Yes $\square$

No $\square$

Details:

* This is a SERIOUS ADVERSE EVENT - will be reported to the Research Ethics Board and your family physician (if permission is granted)

Signature:

Date:

Signature of PI:

Date: 


\title{
Appendix H: Creatine Purity Certificate of Analysis
}

\section{0 [reapure ${ }^{\circ}$}

\section{Certificate of Analysis}

\author{
Customer: \\ AlzChem LLC, MARIETTA, GA 30067, USA \\ Consignee: \\ AlzChem LLC for Cary Company, ADDISON, IL IL 60101, USA \\ Customer Order No.: \\ 4640 \\ Product: \\ Creapure $^{\circledR}$ (ultrapure creatine monohydrate) \\ Lot-No. \\ 515841 \\ Quantity: \\ $5000 \mathrm{~kg}$ \\ Production Date: \\ 07.06 .2015 \\ Retest Date: \\ 07.06 .2018 \\ Manufacturer: \\ AlzChem AG, Trostberg, Germany \\ Country of Origin: \\ Germany
}

This fax is intended only for the use of the above mentioned addresses. It is confidential and may contain legally privileged information. Unauthorized reading, copying, disclosure or use is prohibited. If you received this fax through an error, please destroy your copy and telephone or fax us immediately.

Typical chemical - physical properties: Fine white powder, odorless, flavorless

\begin{tabular}{|l|c|c|c|c|}
\hline Parameter & Method & Unit & Specification & Results \\
\hline Assay $^{1}$ (HPLC) & $107-138 / 1$ & {$[\%]$} & $\geq 99.9$ & 102.0 \\
\hline Creatinine (HPLC) & $107-138 / 1$ & {$[\mathrm{mg} / \mathrm{kg}]$} & $\leq 100$ & 59 \\
\hline Dicyandiamide (HPLC) & $107-138 / 1$ & {$[\mathrm{mg} / \mathrm{kg}]$} & $\leq 50$ & 19 \\
\hline Dihydrotriazine (HPLC) & $107-138 / 1$ & {$[\mathrm{mg} / \mathrm{kg}]$} & $\leq 3$ & $<3$ (=LOD) \\
\hline
\end{tabular}

${ }^{1}$ Calculated as creatine monohydrate; creatine monohydrate theoretically contains $12.1 \%$ water of crystallization.

LOD $=$ Limit of Detection

Office Germany: AlzChem AG, Dr.-Albert-Frank-Straße 32, 83308 Trostberg

Phone +49 8621/86-0, Fax +49 8621/86-2911

Office USA: AlzChem LLC, 650 Village Trace, BIdg. 17, Marietta, GA 30067, USA

Phone 770-804-0371, Fax 770-804-0375

This information and all further technical advice are based on AlzChem's present knowledge and experience. However, AlzChem assumes no liability for providing such information and advice including the extent to which such information and advice may relate to existing third party intellectual property rights, especially patent rights. In particular, AlzChem disclaims all CONDITIONS AND WARRANTIES, WHETHER EXPRESS OR IMPLIED, INCLUDING THE IMPLIED WARRANTIES OF FITNESS FOR A PARTICULAR PURPOSE OF MERCHANTABILITY. ALZCHEM SHALL NOT BE RESPONSIBLE FOR CONSEQUENTIAL, INDIRECT OR INCIDENTAL DAMAGES (INCLUDING LOSS OF PROFITS) OF ANY KIND. AIZChem reserves the right to make any changes according to technological progress or further developments. It is the customer's responsibility and obligation qualified experts. It is the sole responsibility of the customer to carry out and arrange for any such testing. Reference to trade names used by other companies is neither a recommendation, nor an endorsement of any product and does not imply that similar products could not be used. 
Regular controls

Microbiology

\begin{tabular}{|l|c|c|c|c|}
\hline Parameter & Method $^{2}$ & Unit & Specification & Results \\
\hline Moulds and yeasts & $\begin{array}{l}\text { Ph.Eur. } \\
2.6 .12 \text { B }\end{array}$ & {$[\mathrm{cfu} / \mathrm{g}]$} & $\leq 50$ & $<10$ \\
\hline Total aerobic plate counts & $\begin{array}{l}\text { Ph.Eur. } \\
2.6 .12 \mathrm{~B}\end{array}$ & {$[\mathrm{cfu} / \mathrm{g}]$} & $\leq 1000$ & $<10$ \\
\hline Coliform bacteria & $\begin{array}{l}\text { Ph.Eur. } \\
2.6 .12 \text { B }\end{array}$ & {$[\mathrm{neg} / \mathrm{g}]$} & $\mathrm{neg} / \mathrm{g}$ & $\mathrm{neg} / \mathrm{g}$ \\
\hline E. coli & $\begin{array}{l}\text { Ph.Eur. } \\
2.6 .13 \mathrm{~B}\end{array}$ & {$[\mathrm{neg} / \mathrm{g}]$} & $\mathrm{neg} / \mathrm{g}$ & $\mathrm{neg} / \mathrm{g}$ \\
\hline Salmonella sp. & $\begin{array}{l}\text { Ph.Eur. } \\
2.6 .13 \mathrm{~B}\end{array}$ & {$[\mathrm{neg} / 25 \mathrm{~g}]$} & $\mathrm{neg} / 25 \mathrm{~g}$ & $\mathrm{neg} / 25 \mathrm{~g}$ \\
\hline Salmonella sp. & $\begin{array}{l}\S 64 \mathrm{LFGB} \\
\text { L } 00.00-20\end{array}$ & {$[\mathrm{neg} / 375 \mathrm{~g}]$} & -- & $\mathrm{neg} / 375 \mathrm{~g}$ \\
\hline Staphylococcus aureus & $\begin{array}{l}\text { Ph.Eur. } \\
2.6 .13 \mathrm{~B}\end{array}$ & {$[\mathrm{neg} / \mathrm{g}]$} & $\mathrm{neg} / \mathrm{g}$ & $\mathrm{neg} / \mathrm{g}$ \\
\hline
\end{tabular}

Heavy Metals

\begin{tabular}{|l|c|c|c|c|}
\hline Parameter & Method & Unit & Specification & Results \\
\hline Mercury & $107-022 / 1$ & {$[\mathrm{mg} / \mathrm{kg}]$} & $\leq 0.10$ & $<0.011^{3}$ \\
\hline Cadmium & $107-022 / 2$ & {$[\mathrm{mg} / \mathrm{kg}]$} & $\leq 0.1$ & $<0.001^{3}$ \\
\hline Lead & $107-022 / 2$ & {$[\mathrm{mg} / \mathrm{kg}]$} & $\leq 0.1$ & $<0.014^{3}$ \\
\hline Arsenic & $107-022 / 1$ & {$[\mathrm{mg} / \mathrm{kg}]$} & $\leq 0.1$ & $<0.002^{3}$ \\
\hline
\end{tabular}

${ }^{2}$ Ph. Eur. methods harmonised with USP methods, ${ }^{3}$ Limit of Detection

The results based on our measures for quality assurance are in accordance with our specification. For further questions regarding the mentioned figures please fax to +49-8621-86-2860.

\section{AlzChem AG}

Analytical Department

This information and all further technical advice are based on AlzChem's present knowledge and experience. However, AlzChem assumes no liability for providing such information and advice including the extent to which such information and advice may relate to existing third party intellectual property rights, especially patent rights. In particular, AlzChem disclaims all CONDITONS AND WARRANTIES, WHETHER EXPRESS OR IMPLIED, RESPONSIBLE FOR CONSEQUENTIAL, INDIRECT OR INCIDENTAL DAMAGES (INCLUDING IOSS OF PROFITS) OF ANY KIND NOT BE reserves the right to make any changes according to technological progress or further devopments, It is the to carefully inspect and test any incoming goods. Performance of the product(s) described herein should the customer's responsibility and obligation qualified experts. It is the sole responsibility of the customer to carry out and arrange for any such testing. Reference to trade names used by outy by companies is neither a recommendation, nor an endorsement of any product and does not imply that similar products could not be used. 